\title{
Thioureidoalkylphosphonates in the synthesis of 1-aminoalkylphosphonic acids. The Ptc-aminophosphonate method
}

\author{
Marcin H. Kudzin, ${ }^{a}$ Zbigniew H. Kudzin, ${ }^{\text {b } *}$ and Jozef Drabowicz ${ }^{c, d}$ \\ ${ }^{a}$ Textile Research Institute, Brzezinska 5/15, Lodz 92-103, Poland \\ ${ }^{b}$ Faculty of Chemistry, University of Lodz, Tamka 12, Lodz 91-403, Poland \\ ${ }^{c}$ Centre of Molecular and Macromolecular Studies, Polish Academy of Sciences, \\ Sienkiewicza 120a, Lodz 90-363, Poland \\ dJan Dlugosz University, Department of Chemistry and Environment Protection, \\ Armii Krajowej 13/15, Czestochowa, Poland \\ E-mail:zhkudzin@uni.lodz.pl
}

Dedicated to Prof. Dr hab. Heinz Heimgartner on the occasion of his 70th birthday

\begin{abstract}
1-Aminoalkylphosphonic acids $\left(\mathrm{AA}^{\mathrm{P}}\right)$ as structural analogues of protein amino acids $\left(\mathrm{AA}^{\mathrm{C}}\right)$, are important inhibitors of amino acids metabolism. One of the three methods which have contributed to the development of the chemistry of 1-aminoalkylphosphonic acids is the Ptcaminoalkylphosphonate (Phenylthiocarbamoylaminoalkylphosphonate) method which allows a time saving synthesis of structurally diverse $\mathrm{AA}^{\mathrm{P}}$ of analytical purity on mmol-mol scale This review presents a comprehensive survey of this methodology development, with an emphasis on its scope and limitations.
\end{abstract}

Keywords: Amino acids, aminophosphonic acids, 1-aminoalkylphosphonic acids, Ptcaminophosphonate method, Birum reaction, Birum-Oleksyszyn metod, Oleksyszyn method

\section{Table of Contents}

1. Introduction

2. The Origin of the Ptc-aminophosphonate method

2.1. Synthesis of bifunctional 1-aminoalkylphosphonic and 1-aminoaralkylphosphonic acids

2.2. Synthesis of trifunctional sulfur containing 1-aminoalkylphosphonic acids

2.2.1. Functionalization of sulfur containing 1-aminoalkylphosphonic acids

2.2.3. Synthesis of phosphonic analogs of diacidic amino acids

2.2.3. Synthesis of other trifunctional 1-aminoalkylphosphonic acids 
2.2.4. Application of the Ptc-aminophosphonate and related methods for synthesis of optical pure 1-aminoalkylphosphonic acids

2.2.5. Application of the Ptc-aminophosphonate and related methods for synthesis of aminodiesters

3. Other modifications of the Birum and Oleksyszyn procedure

3.1. Z-Aminophosphonate method (Birum-Oleksyszyn method)

3.2. Oleksyszyn method

3.3. Synthesis of 1- $N$-alkyl(aryl)aminoalkylphosphonates

4. Nomenclature and applied abreviations code

5. References

\section{Introduction}

1-Aminoalkylphosphonic acids $\left(\mathrm{AA}^{\mathrm{P}}\right)$ as structural analogues of protein amino acids $\left(\mathrm{AA}^{\mathrm{C}}\right)$, are important inhibitors of enzymes of amino acid metabolism. ${ }^{1-4}$ These properties have been spectacularly reflected in wide-world agrochemical aplications of aminophosphonic herbicidals, [e.g. phosphonomethylglycine $(\mathrm{PMG})^{5-7}$ and also in bacteriostatic applications of mixed phosphono-carboxylic peptides $\left(\mathrm{AA}^{\mathrm{C}}-\mathrm{AA}^{\mathrm{P}}\right)$, [e.g. Phosphaline $\left.\left(\mathrm{R}=\mathrm{R}^{1}=\mathrm{Me}\right)\right]^{8,9}$<smiles>[R]C([NH3+])C(=O)[O-]</smiles>

$A A^{C}$<smiles>[R]C([NH3+])P(=O)([O-])O[2H]</smiles>

$\mathrm{AA}^{\mathrm{P}}$<smiles>O=C(O)C[NH2+]CP(=O)([O-])O</smiles>

PMG<smiles>[R]C([NH3+])C(=O)NC([R])P(=O)([O-])O</smiles>

$A A^{C}-A A^{P}$

Therefore, studies on the synthesis ${ }^{10-12}$ and reactivity of 1-aminoalkylphosphonic acids and their derivatives (e.g. references 11, and 13-15) constitute an important topic in the chemistry and biochemistry of the P-C-N class phosphonates.

Thus, the numerous methods of synthesis of 1-aminoalkylphosphonic acids (1aminoalkylphosphonates) published until now (according to Kafarski and Lejczak, over 6000 papers on the chemistry of aminophosphonates until 2001), ${ }^{3}$ can be classified according to the system given below (Scheme 1):

1. Methods based on simultaneous formation of $\mathrm{P}-\mathrm{C}-\mathrm{N}$ systems $[\mathrm{P}+\mathrm{C}+\mathrm{N} \rightarrow \mathrm{P}-\mathrm{C}-\mathrm{N}]$ :

1.1. Kabachnik-Fields method;

1.2. Amidoalkylation of phosphorus(III) esters;

1.3. Amidoalkylation of phosphorus(III) halides.

2. Methods based on additions of the $\mathrm{P}-\mathrm{H}$ functions to multiple $\mathrm{C}-\mathrm{N}$ bonds $[\mathrm{P}-\mathrm{H} \rightarrow \mathrm{P}-\mathrm{C}-\mathrm{N}]$ (hydrophosphonylation and/or hydrophosphinylation of imines and trazines, hydrazones, azines and oximes, nitrones and nitriles). 


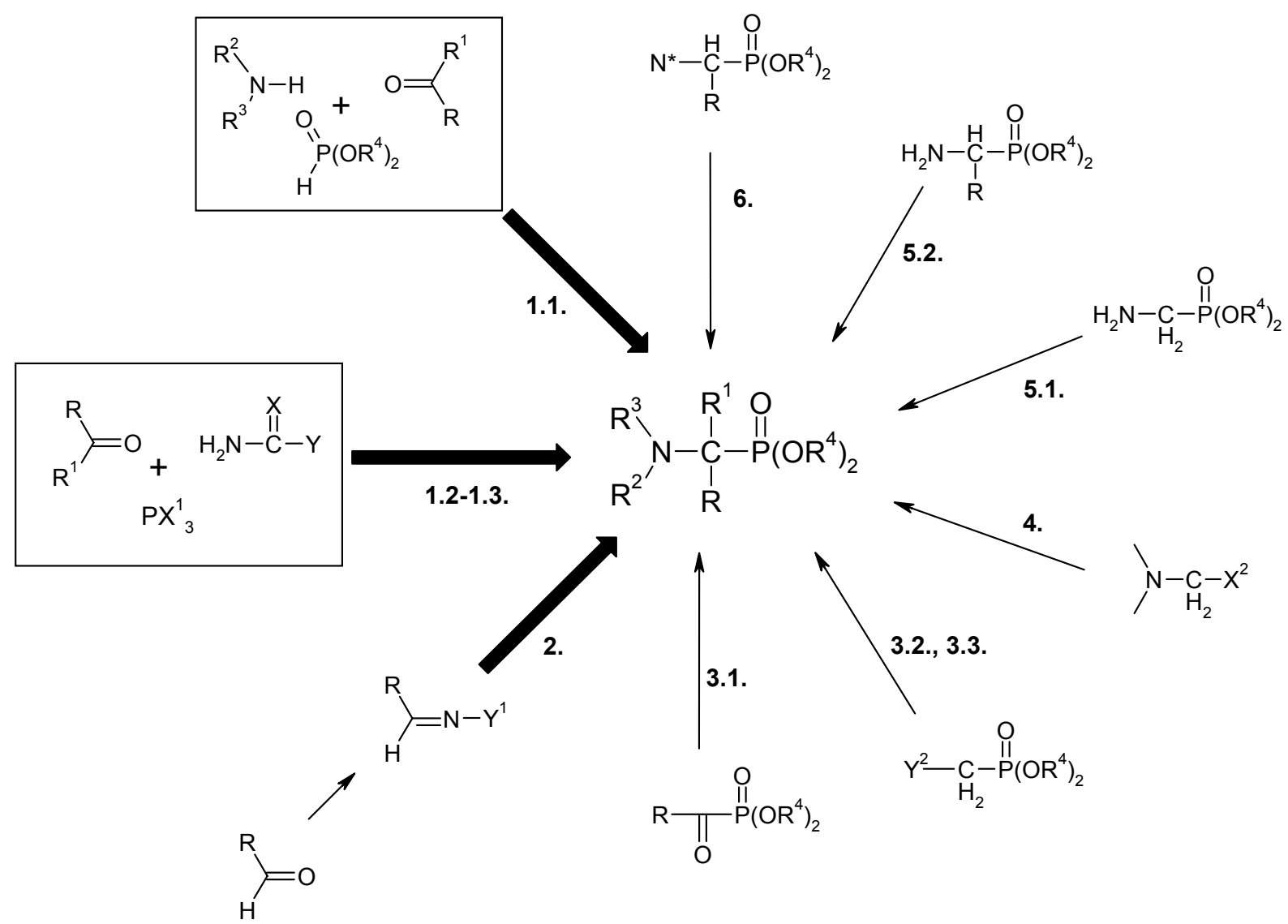

$\mathrm{R}, \mathrm{R}^{1}=\mathrm{H}$, alkyl, aralkyl, aryl; $\mathrm{R}^{2}, \mathrm{R}^{3}=\mathrm{H}, \mathrm{H} ; \mathrm{H}$, alkyl; $\mathrm{H}$, aralkyl; $\mathrm{H}$, aryl; cycloalkyl; alkyl, aryl; $\mathrm{R}^{4}=$ alkyl $\left(\mathrm{Me}, \mathrm{Et}\right.$, iPr), aryl $(\mathrm{Ph})$, aralkyl $(\mathrm{Bn})$ and $\mathrm{H} ; \mathrm{X}=\mathrm{O}, \mathrm{S} ; \mathrm{X}^{1}=\mathrm{Cl}, \mathrm{HO}, \mathrm{RO}, \mathrm{ArO} ; \mathrm{X}^{2}=\mathrm{Cl}, \mathrm{Br}, \mathrm{RO}$; $\mathrm{Y}=\mathrm{BnO}, \mathrm{PhNH} ; \mathrm{Y}^{1}=\mathrm{R}, \mathrm{NH}_{2}, \mathrm{RNH}, \mathrm{R}_{2} \mathrm{~N}, \mathrm{HO} ; \mathrm{Y}^{2}=\mathrm{Cl}, \mathrm{HO}$ (3.2.); $\mathrm{Me}, \mathrm{Ph}, \mathrm{RO}-\mathrm{C}(\mathrm{O})-($ 3.3.);

$\mathrm{N}^{*}=\mathrm{N}_{3}, \mathrm{NO}_{2}, \mathrm{H}_{2} \mathrm{~N}-\mathrm{NH}$

\section{Scheme 1}

3. Methods based on $\alpha$-amination of functionalized alkylphosphonates $[\mathrm{P}-\mathrm{C}+\mathrm{N} \rightarrow \mathrm{P}-\mathrm{C}-\mathrm{N}]$ :

3.1. Reductive amination of 1-ketophosphonates;

3.2. Nucleophilic aminations of alkylphosphonates;

3.3. Electrophilic aminations of alkylphosphonates).

4. Methods based on nucleophilic substitution with phosphoroorganic nucleophiles $[\mathrm{P}+\mathrm{X}-\mathrm{C}-\mathrm{N}$

$\rightarrow \mathrm{P}-\mathrm{C}-\mathrm{N}+\mathrm{X}]$ (Arbusov reaction derived methods).

5. Methods based on modifications of the carbon chain of 1-aminoalkylphosphonates $[\mathrm{P}-\mathrm{C}(\mathrm{R})-\mathrm{N}$

$\left.\rightarrow \mathrm{P}-\mathrm{C}\left(\mathrm{R}^{*}\right)-\mathrm{N}\right]$ :

5.1. Nucleophilic or electrophilic alkylation of derivatives of phosphonoglycinate;

5.2. modifications of the carbon side chain of aminoalkylphosphonates. 
6. Methods based on modifications of phosphorus functions $\left[\mathrm{P}-\mathrm{C}-\mathrm{N} \rightarrow \mathrm{P}^{*}-\mathrm{C}-\mathrm{N}\right.$ ] (oxidation of 1-aminoalkylphosphinic acids into 1-aminoalkylphosphonic analogues).

7. Methods based on modifications of nitrogenic functions [P-C-N $\rightarrow$ P-C-N*] (reduction of 1azidoalkylphosphonates and 1-nitroalkylphosphonates, reduction of oximes, hydrazones, azines, etc.)

8. Other methods.

However, the crucial events in the chemistry of phosphonic analogues of protein amino acids (1-aminoalkylphosphonic acids bearing with the primary amino function: $\mathrm{R}^{2}=\mathrm{R}^{3}=\mathrm{H}$; Scheme 1) took place in the late 1970s and were connected with two discoveries. The first was made by Birum $^{16}$ and is related to the easy and high yield reactions of ureas with aldehydes and esters of phosphorus(III) oxo-acids (Scheme 2). [In this review, the phosphonic acids and derivatives are named through abbreviations, the code for these abbreviations is listed in Section 4 (Table 12)].

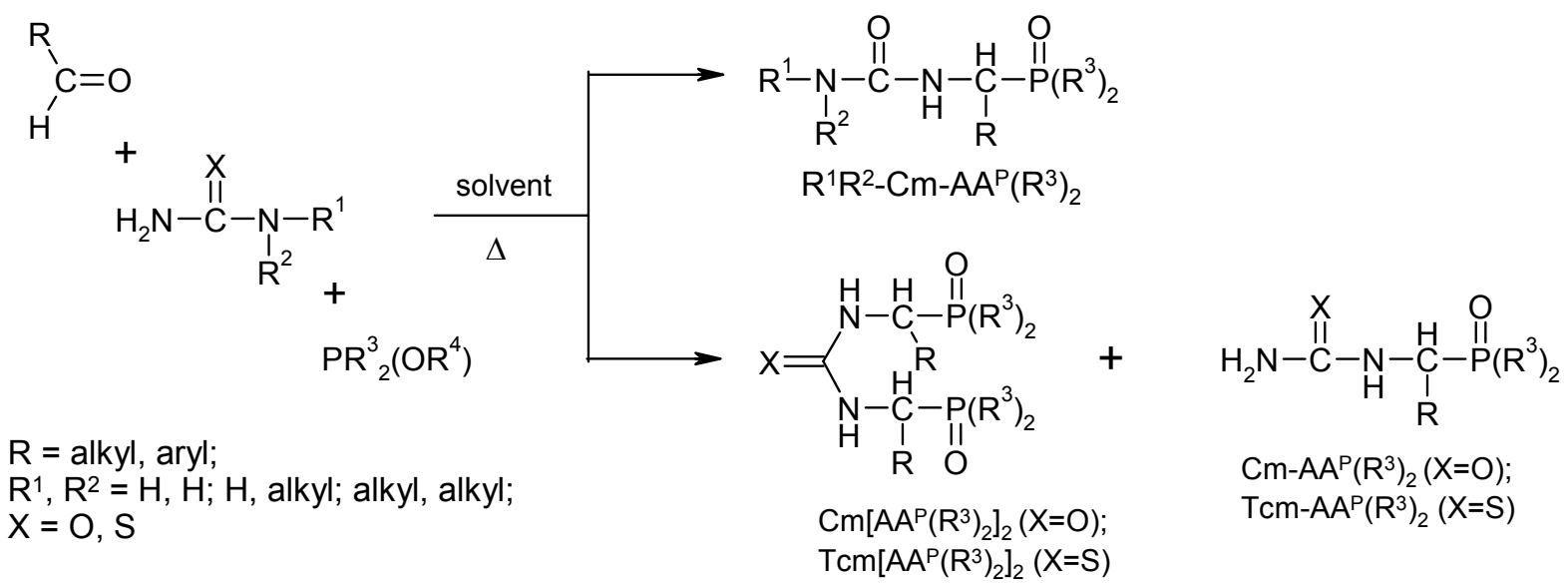

\section{Scheme 2}

Their scope was extended by the use of other amide components, including sulfamides, sulfonamides and carbamates [patents of Birum ${ }^{17-21}$ ].

The products of the Birum condensation (Table 1) contain the P-C-N bond system characteristic for 1-aminoalkylphosphonic acids. However, attempts on their degradation, carried out by Birum for $\mathrm{Cm}-\mathrm{AA}^{\mathrm{P}}(\mathrm{OPh})_{2}$ and/or $\mathrm{Cm}-\left[\mathrm{AA}^{\mathrm{P}}(\mathrm{OPh})_{2}\right]_{2}$, revealed low to moderate stability of the ester functions and higher stability at applied conditions of the amide function (Scheme 3 ). 


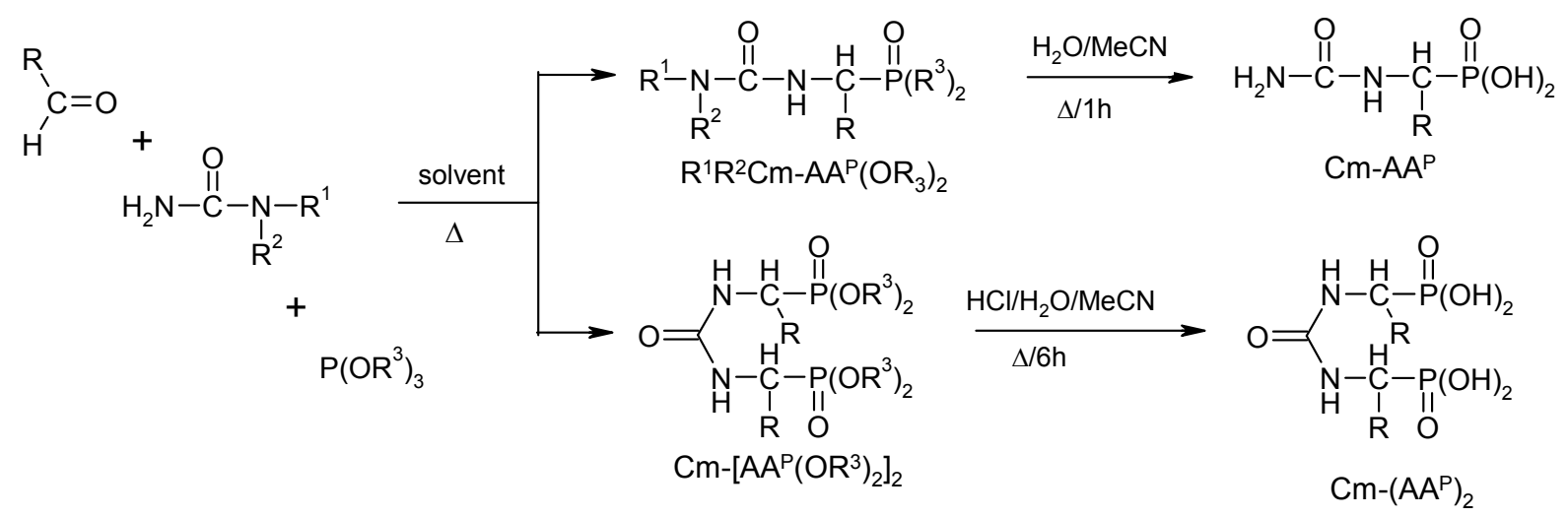

\section{Scheme 3}

As a matter of fact, the degradation of Pc-Ala ${ }^{\mathrm{P}}(\mathrm{OEt})_{2}$ and/or $\mathrm{Pc}-\mathrm{Pgly}{ }^{\mathrm{P}}(\mathrm{OEt})_{2}\left(\mathrm{R}^{1}=\mathrm{Ph} ; \mathrm{R}^{2}=\mathrm{H}\right.$; $\mathrm{R}^{3}=\mathrm{Et}$ ) to the corresponding $\mathrm{AA}^{\mathrm{P}}$, carried out by Huber and Middlebrooks a few years later, ${ }^{22}$ required relatively harsh conditions ( $72 \mathrm{~h}$ of reflux in $10 \mathrm{M} \mathrm{HCl}$ aq.).

The second contribution was made by Oleksyszyn, who not only recognized the practical value of the Birum condensations, ${ }^{23-25}$ but also the Engelman and Pikl amidoalkylations of phosphorus trichloride ${ }^{25-28}$ (Section 3).

In the Birum condensation, which formally can be considered as a variant of the Arbuzov reaction, and also as a type of the amidoalkylation of phosphorus(III) esters, the key electrophilic reagent prepared in situ from an amide substrate and an aldehyde, adds to the corresponding phosphite (phosphonite, phosphinite) afford the variety of structurally diverse P-C-N products (Scheme 4, Table 1).

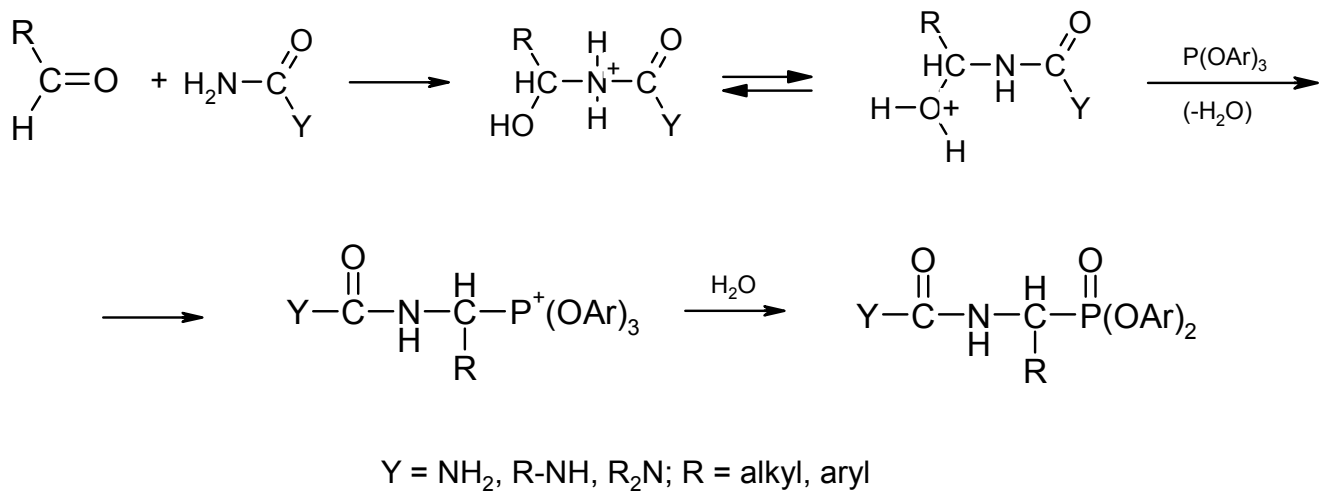

\section{Scheme 4}

Modification of the Birum reaction, in which ureas (thiourea) were replaced by $N$ phenylthiourea (A: Ptc-aminophosphonate $\operatorname{method}^{29,30}$ and/or by $N$-benzyl carbamates (C: Zaminophosphonate method, Birum-Oleksyszyn method) ${ }^{23,25}$ (Section 3.1.) (Scheme 5) and modification of the amidoalkylation Engelman-Pikl reaction by Oleksyszyn ${ }^{25,28}$ (Section 3.2.) 
created three excellent protocols exceeding earlier procedures in terms of simplicity and yields. ${ }^{10-12}$

Table 1. Characterization of representative products of the Birum condensation ${ }^{16}$

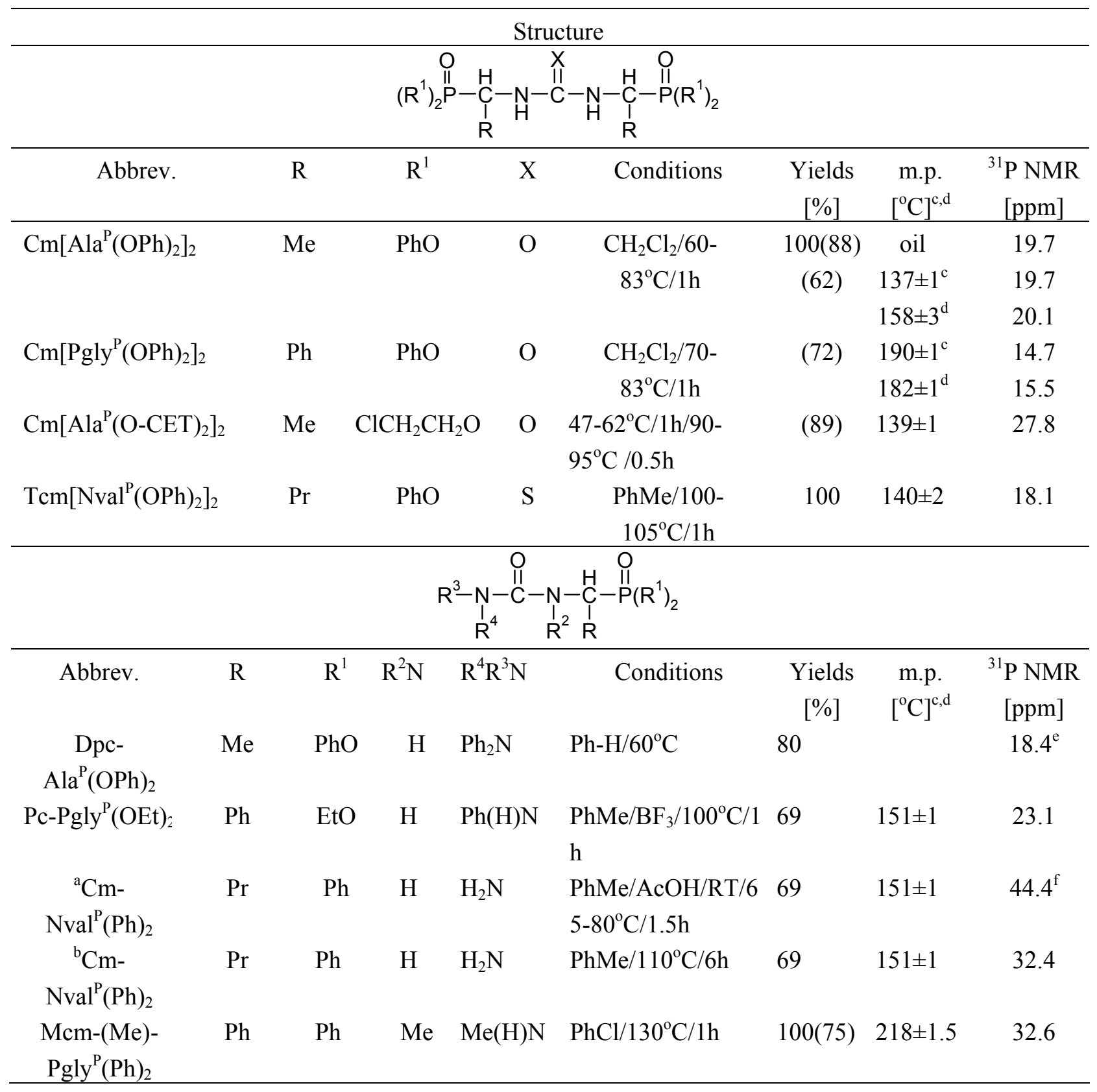

${ }^{\mathrm{a}}$ Synthesized from $\mathrm{Ph}_{2} \mathrm{P}(\mathrm{OEt})$; ${ }^{\mathrm{b}}$ Synthesized from $\mathrm{Ph}_{2} \mathrm{P}(\mathrm{OPh})$. Yields: ${ }^{31} \mathrm{P}$ NMR or isolated yields (in brackets). M.p.: ${ }^{(\mathrm{c})}$ I fraction $\&{ }^{(\mathrm{d})} \mathrm{II}$ fraction. ${ }^{31} \mathrm{P}$ NMR: solutions in $\mathrm{CDCl}_{3} ; \mathrm{PhH}^{(\mathrm{e})}$ or $\mathrm{THF}^{(\mathrm{f})}$ 


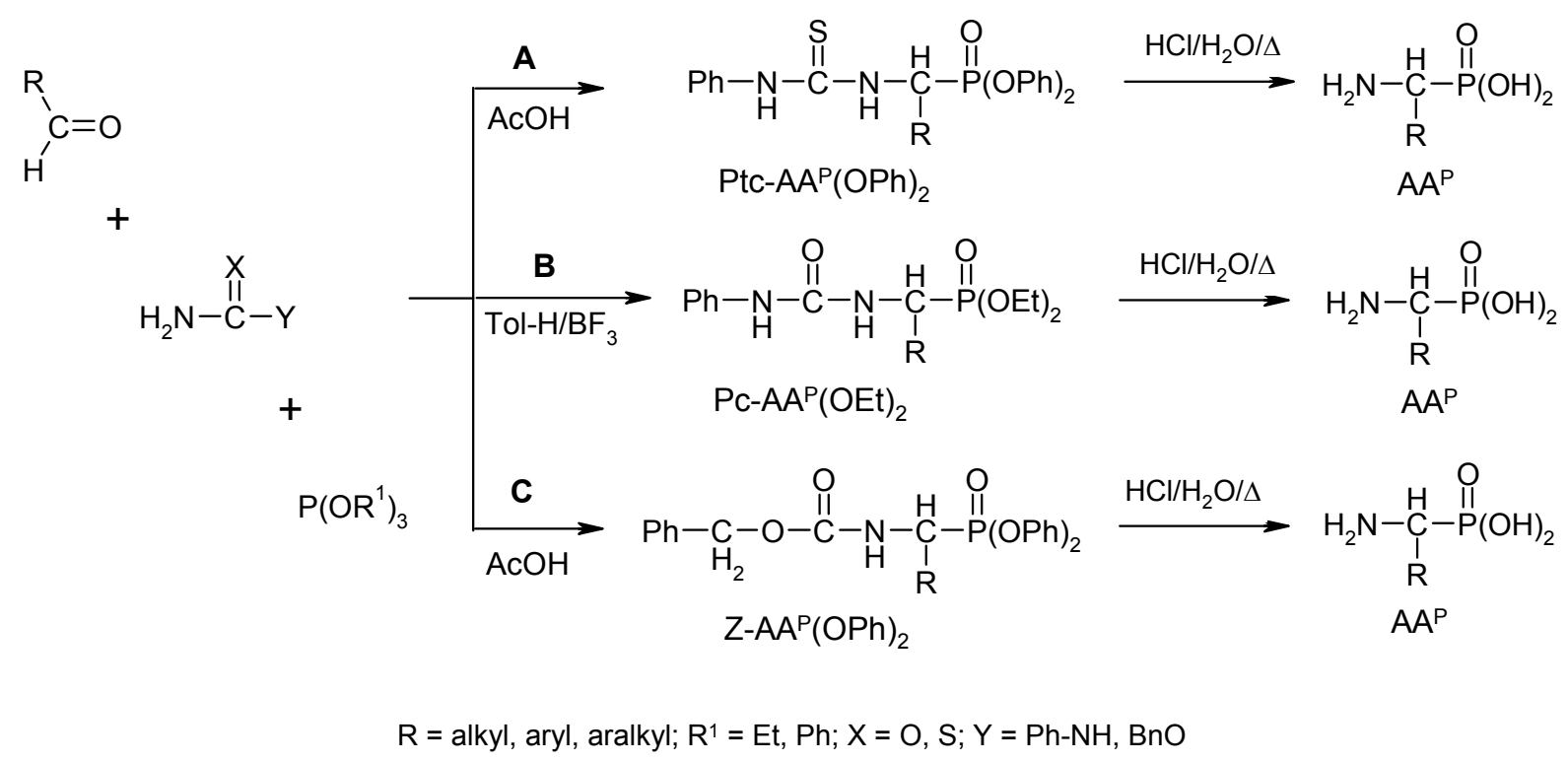

\section{Scheme 5}

In this review, we present the results on the origin and developments of Ptcaminophosphonate method.

\section{The origin of the Ptc-aminophosphonate method}

Until the 1980s the most efficient procedures for the synthesis of compounds containing the NC-P bond system were based on an addition of a phosphorus nucleophile to imine bonds (usually imines derived from benzylamine and its analogs), followed by the amine group deprotection. ${ }^{10,12}$ Therefore the 1-aminoalkylphosphonate research at these decades was directed mainly on the search for labile imine-derivatives - substrates for a phosphite addition. As a part of this research program, developed in the Stec laboratory, ${ }^{31-34}$ we started with the examination on the addition of phosphorus nucleophiles into the $\mathrm{C}=\mathrm{N}$ bond of thiourea-aldehyde adducts formed easily in aqueous acidic solutions of aldehydes and thiourea ${ }^{35}$ (Scheme 6).

However, the deeper investigation of these additions carried out in wide set of reaction conditions and monitored by ${ }^{31} \mathrm{P}$ NMR, revealed the formation of compounds exhibiting characteristic for 1-aminoalkylphosphonate chemical shifts ( $\sim 15-17 \mathrm{ppm})$ in low amounts.

Therefore, in an alternative approach, we applied the variant of the Birum reaction in which a toluene solution of alkanal, thiourea and triphenyl phosphite was converted upon heating $\left(110^{\circ} \mathrm{C}\right)$ into a mixture of thioureidoalkylphosphonate $\mathrm{Tcm}-\mathrm{AA}^{\mathrm{P}}(\mathrm{OPh})_{2}$ and thiourylenebis(alkylphosphonate) Tcm- $\left[\mathrm{AA}^{\mathrm{P}}(\mathrm{OPh})_{2}\right]_{2}$. Their very slow hydrolytic degradation $(24 \mathrm{~h}$ of reflux in $10 \mathrm{M} \mathrm{HCl}$ solution) gave the expected 1-aminoalkylphosphonic acids with yields of ca. $30-40 \%$ (Scheme 7). 


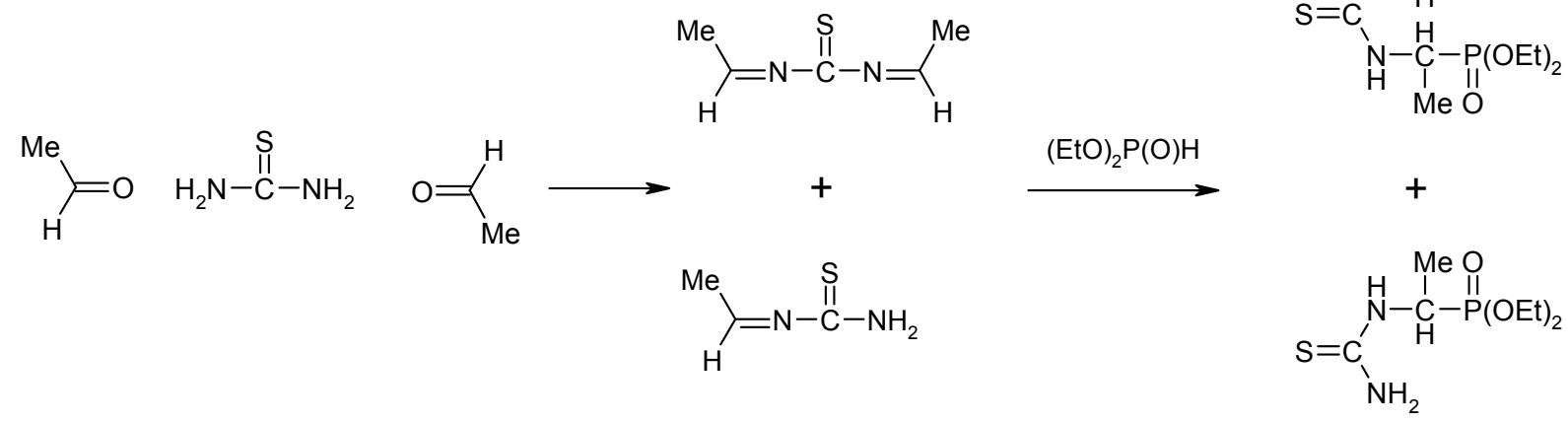

\section{Scheme 6}

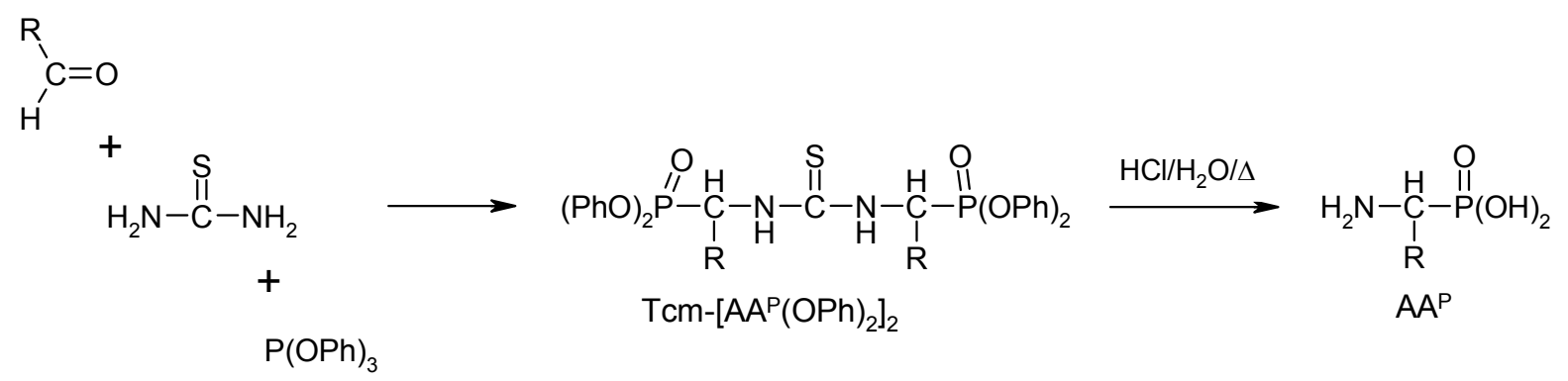

\section{Scheme 7}

However, due to the requirement of thermal activation, the applied conditions of condensation eliminated application of volatile, low molecular aldehydes (e.g. acetaldehyde). Also low yields of the degradation of so formed thiourylenebis(alkylphosphonates) Tcm$\left[\mathrm{AA}^{\mathrm{P}}(\mathrm{OPh})_{2}\right]_{2}$ induced the search for more labile thiourea derivatives which afford more prone to the degradation tioureidoalkylphosphonates.

The survey of thiourea structures suggested the use of $N$-phenylthiourea as an amide substrate for these tri-component condensations. It is easily degradable under acidic hydrolysis to $N$-phenylisothiocyanate and ammonia. ${ }^{36}$

The mechanistic analysis of this condensation, confirms the Birum suggestions on the role of acidic catalyst in the reactions (Table 2). We have found, that the condensations carried out in glacial acetic acid occur spontanously, usually with a slight exothermic effect. The application of $\mathrm{N}$-phenylthiourea as the amide component of condensation, resulted in the high yields formations of the corresponding $N$-phenylthioureidoalkylphosphonates $\left[\mathrm{Ptc}-\mathrm{AA}^{\mathrm{P}}(\mathrm{OPh})_{2}\right]$, which in majority underwent spontaneous crystallization from the reaction mixtures. These Ptc- $\mathrm{AA}^{\mathrm{P}}(\mathrm{OPh})_{2}$ compounds during acidic hydrolysis (6-8h of reflux in mixtures $\mathrm{HCl} / \mathrm{H}_{2} \mathrm{O} / \mathrm{AcOH}$ ) underwent the quantitative degradations to the corresponding 1-aminoalkylphosphonic acids (Scheme 8). 


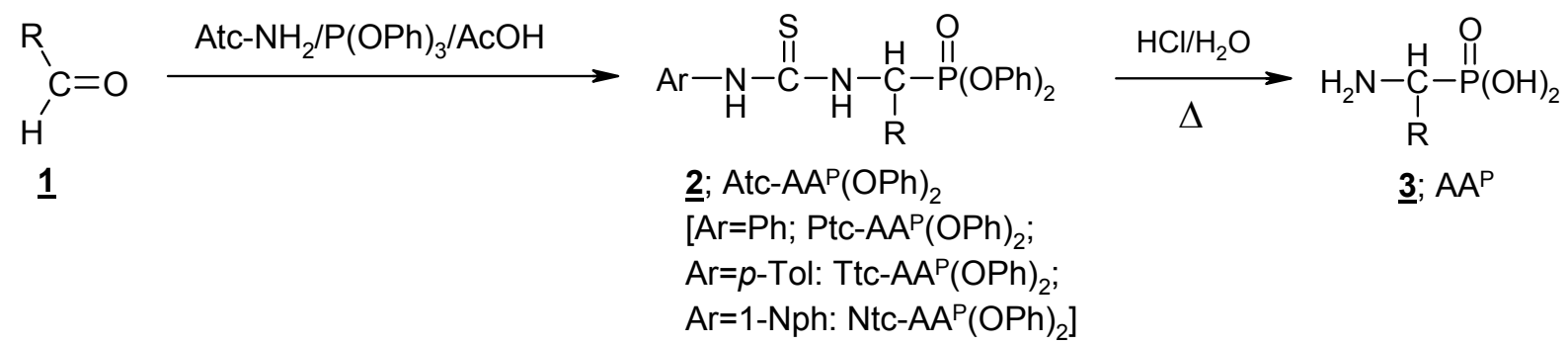

\section{Scheme 8}

Diphenyl Ptc-aminoalkylphosphonates have also attracted considerable interest as model compounds for structural studies. ${ }^{37-42}$

\subsection{Synthesis of bifunctional 1-aminoalkylphosphonic and 1-aminoaralkylphosphonic acids} The application of the tri-component condensation of $N$-phenylthiourea, alkanals or aromatic aldehydes and triphenyl phosphite gave various diphenyl 1-(Ptc-amino)alkylphosphonates, which upon hydrolytic, acidic degradation afforded bifunctional 1-aminoalkylphosphonic and 1aminoaralkylphosphonic acids (Tables 2 and 3). Using this protocol we have synthesized several phosphonic analogs of the protein amino acids, including $\mathrm{Ala}^{\mathrm{P}}, \mathrm{Val}^{\mathrm{P}}, \mathrm{Leu}^{\mathrm{P}}, \mathrm{Il}^{\mathrm{P}}, \mathrm{Phe}^{\mathrm{P}}$, as well as their homologs, compounds known from their biological activity. ${ }^{1-4,43}$ Herbicidal properties of the aryl-containing 1-aminophosphonic acids ${ }^{44-46}$ sugested us the synthesis of their analogs (Table 2).

Preparation of thioureidoalkylphosphonates $\mathbf{P t c}_{-\mathbf{A}} \mathbf{A}^{\mathbf{P}}(\mathbf{O P h})_{2} \quad[$ Kudzin\&Stec, Synthesis 1978 $]^{29}$

To a solution of triphenyl phosphite $(0.02 \mathrm{~mol})$ and aldehyde $(0.025 \mathrm{~mol})$ in glacial acetic acid $(10 \mathrm{ml})$ is added the powdered $\mathrm{N}$-phenylthiourea $\left(\mathrm{Ptc}-\mathrm{NH}_{2}: 0.02 \mathrm{~mol}\right)$ in one portion. Addition of Ptc- $\mathrm{NH}_{2}$ is accompanied with a slight exothermic effect. The reaction mixture is stirred at room temperature for $0.5 \mathrm{~h}$ and for next $0.5 \mathrm{~h}$ at $80^{\circ} \mathrm{C}$ (oil-bath). After cooling of the reaction mixture to room temperature, water $(5 \mathrm{ml})$ is added and the solution was maintained at room temperature for $10 \mathrm{~h}$. The precipitate is filtered off, washed with acetic acid/water (1:1), dried over potassium hydroxide in an evacuated dessicator, and recrystallized from chloroform/methanol. The yields and physical constants of all products $\mathrm{Ptc}-\mathrm{AA}^{\mathrm{P}}(\mathrm{OPh}) 2$ are given in Table 2.

Preparation of 1-aminoalkylphosphonic acid; Procedure A [Kudzin\&Stec, Synthesis 1978] ${ }^{29}$ Compound Ptc- $\mathbf{A A} \mathbf{P}^{\mathbf{P}}(\mathbf{O P h})_{2}(0.005 \mathrm{~mol})$ is dissolved in a mixture of glacial acetic acid $(1 \mathrm{ml})$ and hydrochloric acid $(36 \%, 10 \mathrm{ml})$ and heated under reflux for $7 \mathrm{~h}$. The solvents are evaporated under reduced pressure and the residue is dissolved in ethanol $(20 \mathrm{ml})$. The ethanolic solution of the amino acid hydrohalide is treated with methyloxirane until $\mathrm{pH} 6$ is reached. The precipitated aminoalkanephosphonic acid is filtered off, washed with ethanol, and dried in vacuum over potassium hydroxide. Recrystallization from ethanol/water gives the desired aminoalkanephosphonic acid. The yields and analytical data are collected in Table 2 and 3. 
Preparation of 1-aminoalkylphosphonic acid; Procedure B [Kudzin\&Stec, Synthesis 1978] When $\mathrm{N}$-Ph- $\mathrm{CH}(\mathrm{Me})$-thiourea $\left(\mathrm{Bmtc}-\mathrm{NH}_{2}\right)$ were applied, the formed thioureidophosphonate Bmtc-AA ${ }^{\mathrm{P}}(\mathrm{OPh})_{2}(5 \mathrm{mmol})$ is heated under reflux for $3 \mathrm{~h}$ in acetic anhydride/acetic acid $(5 \mathrm{ml}$ and $1 \mathrm{ml}$, respectively). Aqueous hydrobromic acid $(\mathrm{d}=1.38 \mathrm{~g} / \mathrm{ml}, 5 \mathrm{ml})$ is then added dropwise and heating is continued for $7 \mathrm{~h}$.] The solvents are evaporated under reduced pressure and the residue is dissolved in ethanol $(20 \mathrm{ml})$. The ethanolic solution of the amino acid hydrohalide is treated with methyloxirane until pH 6 is reached. The precipitated aminoalkylphosphonic acid is filtered off, washed with ethanol, and dried in vacuum over potassium hydroxide. Recrystallization from ethanol/water gives the desired aminoalkanephosphonic acid. The yields and analytical data are collected in Table 2 and 3.

Table 2. Bifunctional 1-aminoalkylphosphonic acids

\begin{tabular}{|c|c|c|c|c|c|c|c|c|c|c|c|}
\hline \multirow[t]{4}{*}{$\mathrm{AA}^{\mathrm{P}}$} & \multicolumn{4}{|c|}{ Ptc-AA ${ }^{\mathrm{P}}(\mathrm{OPh})_{2}$} & \multicolumn{6}{|c|}{$\mathrm{AA}^{\mathrm{P}}$} & \multirow[t]{4}{*}{ Lit. } \\
\hline & \multirow[t]{3}{*}{$\begin{array}{l}\text { Yield } \\
{[\%]}\end{array}$} & \multirow[t]{3}{*}{$\begin{array}{l}\mathrm{m} . \mathrm{p} . \\
{\left[{ }^{\circ} \mathrm{C}\right]}\end{array}$} & \multicolumn{2}{|c|}{$\begin{array}{c}{ }^{31} \mathrm{P} \text { NMR } \\
{[\mathrm{ppm}]}\end{array}$} & \multicolumn{2}{|c|}{ Yield [\%] } & \multirow[t]{3}{*}{$\begin{array}{l}\text { m. p. } \\
{\left[{ }^{\circ} \mathrm{C}\right]}\end{array}$} & \multicolumn{3}{|c|}{${ }^{31} \mathrm{P}$ NMR [ppm] } & \\
\hline & & & $\mathrm{AcOH}$ & $\mathrm{CDCl}_{3}$ & $\underline{\mathbf{2}} \rightarrow \underline{\mathbf{3}}$ & $\underline{1} \rightarrow \underline{3}$ & & $2 \mathrm{M}$ & $\mathrm{H}_{2} \mathrm{O}$ & $2 \mathrm{M}$ & \\
\hline & & & & & & & & $\mathrm{HCl}$ & & $\mathrm{NaOH}$ & \\
\hline $\mathrm{Ala}^{\mathrm{P}}$ & 85 & $156-157$ & 17.6 & & 93 & 91 & $275-276$ & 16.8 & 14.3 & 22.3 & 29 \\
\hline Hala $^{\mathrm{P}}$ & 86 & $159-161$ & 16.7 & & 98 & 86 & $265-266$ & 16.8 & 13.7 & 22.0 & \\
\hline $\mathrm{Nval}^{\mathrm{P}}$ & 89 & $155-156$ & 16.8 & & 97 & 83 & $262-264$ & 16.8 & 13.9 & 22.0 & \\
\hline $\mathrm{Val}^{\mathrm{P}}$ & 77 & $158-159$ & 16.2 & 17.5 & 92 & 72 & $261-262$ & 15.7 & 13.0 & 21.2 & \\
\hline $\mathrm{Nleu}^{\mathrm{P}}$ & 81 & $161-162$ & 16.9 & 18.0 & & 80 & $262-264$ & 16.5 & 14. & 21.7 & \\
\hline \multirow[t]{2}{*}{ Leu $^{P}$} & & & & & & 80 & $266-268$ & 16.2 & 13.4 & 21.2 & \\
\hline & & & & & & & $279-280$ & & & & 47 \\
\hline \multirow[t]{2}{*}{ Ileu $^{\mathrm{P}}$} & & & & & & 85 & $261-263$ & 15.0 & 12.0 & 20.6 & \\
\hline & & & & & & & $271-272$ & & & & 47 \\
\hline \multirow[t]{2}{*}{ Tleu $^{P}$} & 80 & $181-182$ & & 16.9 & & 88 & $245-250$ & 15.3 & 13.0 & 20.8 & \\
\hline & & & & & & & $245-253$ & & & & 48 \\
\hline \multirow[t]{3}{*}{$\mathrm{Hnle}^{\mathrm{P}}$} & 78 & $157-159$ & & 16.9 & & 80 & $267-269$ & 16.5 & 14. & 21.7 & \\
\hline & & & & & & & $269-271$ & & & & 49 \\
\hline & & & & & & & $274-277$ & & & & 50 \\
\hline
\end{tabular}

Preparation of 1-aminoalkylphosphonic acids; "One-pot" procedure C [Kudzin\&Stec, Synthesis 1978 $]^{29}$

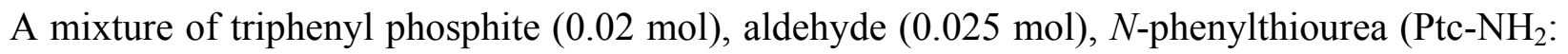
$0.02 \mathrm{~mol})$ in glacial acetic acid $(10 \mathrm{ml})$ is stirred for $1 \mathrm{~h}$ at $80^{\circ} \mathrm{C}$ (oil-bath) and, without isolation, formed Ptc- $\mathrm{AA}^{\mathrm{P}}(\mathrm{OPh})_{2}$ is degraded. In cases when phenylthiourea is a reaction component, aqueous hydrochloric acid $(36 \%, 20 \mathrm{ml})$ is used for cleavage of the N-C(S) bond. Bmtc- 
$\mathrm{AA}^{\mathrm{P}}(\mathrm{OPh})_{2}$ derivatives required treatment with acetic anhydride/ acetic acid followed by aqueous hydrobromic acid as stated above. Isolation is analogous to that described for procedure $\mathbf{A}$.

Table 3. Bifunctional 1-aminoaralkylphosphonic acids

\begin{tabular}{|c|c|c|c|c|c|c|c|c|c|c|}
\hline \multirow{3}{*}{\multicolumn{2}{|c|}{$\begin{array}{c}\mathrm{AA}^{\mathrm{P}} \\
\mathrm{Ar}-\stackrel{\mathrm{H}}{\mathrm{C}}-\stackrel{\mathrm{O}}{\mathrm{P}}(\mathrm{OH})_{2} \\
\mathrm{NH}_{2}\end{array}$}} & \multicolumn{4}{|c|}{$\operatorname{Ptc}^{-A A}{ }^{\mathrm{P}}(\mathrm{OPh})_{2}$} & \multicolumn{4}{|c|}{$\mathrm{AA}^{\mathrm{P}}$} & \multirow[t]{4}{*}{ Lit. } \\
\hline & & \multirow[t]{3}{*}{$\begin{array}{l}\text { Yield } \\
{[\%]}\end{array}$} & \multirow[t]{3}{*}{$\begin{array}{l}\text { m.p. } \\
{\left[{ }^{\circ} \mathrm{C}\right]}\end{array}$} & \multirow{2}{*}{\multicolumn{2}{|c|}{$\begin{array}{c}{ }^{31} \mathrm{P} \text { NMR } \\
{[\mathrm{ppm}]}\end{array}$}} & \multirow{3}{*}{$\begin{array}{c}\text { Yield } \\
{[\%]} \\
\underline{\mathbf{1}} \rightarrow \underline{\mathbf{3}}\end{array}$} & \multirow[t]{3}{*}{$\begin{array}{l}\text { m.p. } \\
{\left[{ }^{\circ} \mathrm{C}\right]}\end{array}$} & \multicolumn{2}{|c|}{$\begin{array}{c}{ }^{31} \mathrm{P} \text { NMR } \\
{[\mathrm{ppm}]}\end{array}$} & \\
\hline & & & & & & & & $2 \mathrm{M}$ & $2 \mathrm{M}$ & \\
\hline Structure & Abbrev. & & & \multicolumn{2}{|c|}{$\mathrm{CDCl}_{3} \quad \mathrm{AcOH}$} & & & & & \\
\hline & PGly $^{\mathrm{P}}$ & 85 & $\begin{array}{l}169- \\
170\end{array}$ & 15.4 & 13.4 & 70 & $\begin{array}{c}269- \\
271\end{array}$ & 12.5 & 18.0 & 29 \\
\hline & $\begin{array}{l}\text { 2-MP- } \\
\text { Gly }^{\mathrm{P}}\end{array}$ & 85 & $\begin{array}{c}169- \\
170\end{array}$ & 15.0 & & 70 & $\begin{array}{l}252- \\
254\end{array}$ & 13.4 & 19.0 & \\
\hline & $\begin{array}{l}\text { 3-MP- } \\
\text { Gly }^{\mathrm{P}}\end{array}$ & 82 & $\begin{array}{l}154- \\
158\end{array}$ & 15.7 & & 90 & $\begin{array}{r}234- \\
236\end{array}$ & 13.2 & 18.6 & \\
\hline & $\begin{array}{l}\text { 4-MP- } \\
\text { GlyP }^{\mathrm{P}}\end{array}$ & 90 & $\begin{array}{l}192- \\
195\end{array}$ & 15.5 & & 97 & $\begin{array}{c}246- \\
248\end{array}$ & 13.3 & 18.7 & \\
\hline & $\begin{array}{l}\text { 2-NP- } \\
\text { Gly }^{\mathrm{P}}\end{array}$ & 68 & $\begin{array}{l}164- \\
166\end{array}$ & 13.7 & & 45 & $\begin{array}{r}246- \\
249\end{array}$ & 10.8 & 17.2 & \\
\hline & $\begin{array}{l}\text { 3-NP- } \\
\text { Gly }^{\mathrm{P}}\end{array}$ & 76 & $\begin{array}{l}146- \\
149\end{array}$ & 14.5 & & 90 & $\begin{array}{c}231- \\
233\end{array}$ & 11.2 & 17.1 & \\
\hline & $\begin{array}{l}\text { 4-NP- } \\
\text { Gly }^{\mathrm{P}}\end{array}$ & 34 & $\begin{array}{l}165- \\
168\end{array}$ & 14.1 & & 37 & $\begin{array}{c}223- \\
224\end{array}$ & 10.9 & 16.8 & \\
\hline & $\begin{array}{l}\text { 2-CP- } \\
\text { Gly }^{\mathrm{P}}\end{array}$ & 81 & $\begin{array}{l}130- \\
134\end{array}$ & 14.5 & & 49 & $\begin{array}{l}235- \\
237\end{array}$ & 11.8 & 18.0 & \\
\hline & $\begin{array}{l}\text { 4-BP- } \\
\text { Gly }\end{array}$ & 68 & $\begin{array}{l}177- \\
179\end{array}$ & 14.7 & & & $\begin{array}{c}254- \\
256\end{array}$ & & 18.1 & \\
\hline & $\begin{array}{l}\text { 1-Nph- } \\
\text { Gly }^{\mathrm{P}}\end{array}$ & 60 & $\begin{array}{l}182- \\
184\end{array}$ & 15.3 & & 75 & $\begin{array}{l}255- \\
257\end{array}$ & 13.0 & 18.8 & \\
\hline & $\begin{array}{l}\text { 2-Nph- } \\
\text { Gly }^{\mathrm{P}}\end{array}$ & 70 & $\begin{array}{c}177- \\
179\end{array}$ & 15.5 & & 91 & $\begin{array}{l}235- \\
237\end{array}$ & 12.9 & 18.4 & \\
\hline O & $\begin{array}{l}\text { 2-Fu- } \\
\text { Gly }^{\mathrm{P}}\end{array}$ & 60 & $\begin{array}{l}150- \\
152\end{array}$ & 12.8 & & $\mathrm{a}$ & & & & \\
\hline
\end{tabular}


Table 3. Continued

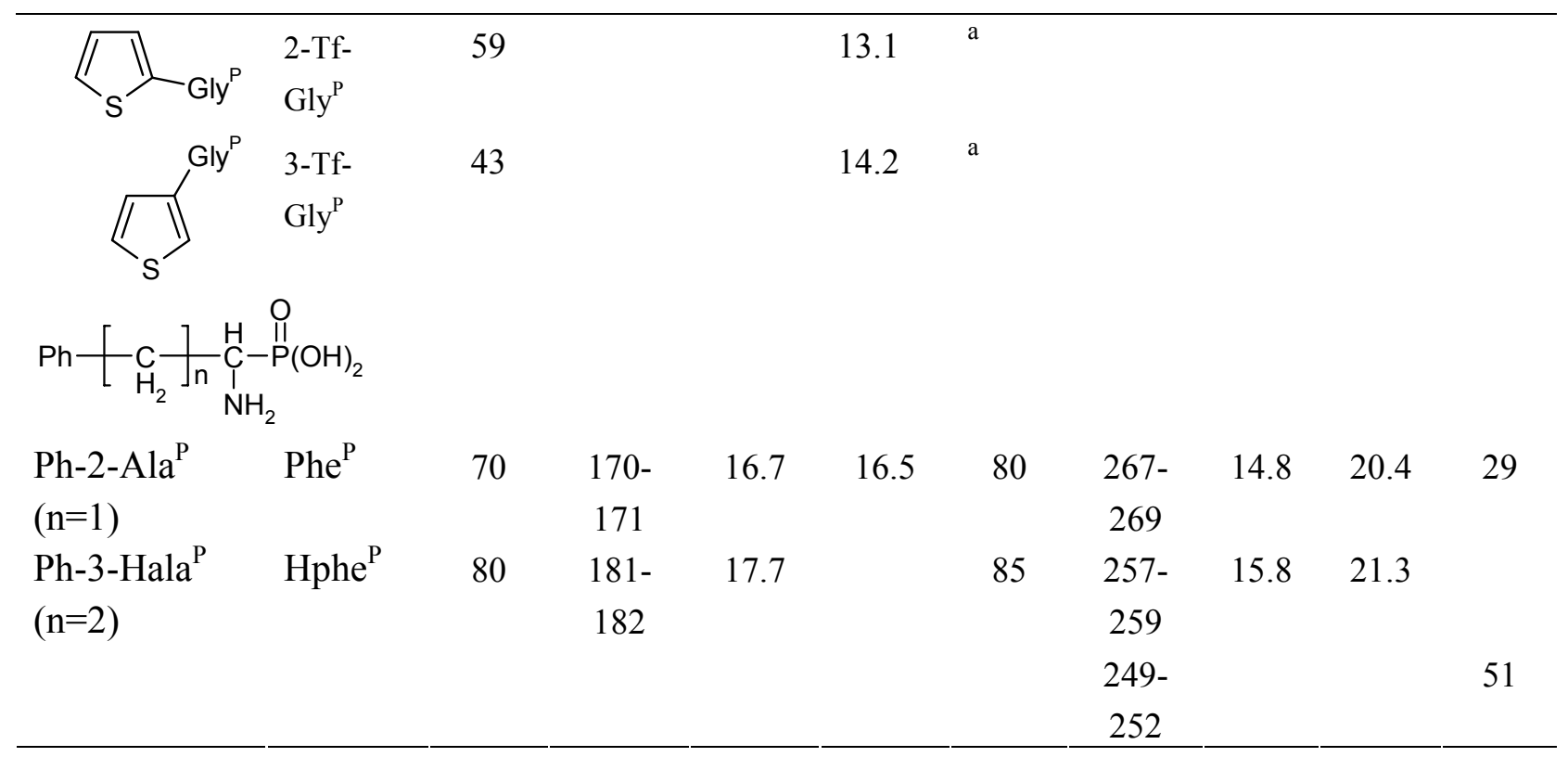

${ }^{\mathrm{a}}$ Standard hydrolytic degradations of the corresponding Ptc-Hetgly ${ }^{\mathrm{P}}(\mathrm{OPh})_{2}[\mathrm{AcOH} / 10 \mathrm{M} \mathrm{HCl}$ (1:1), $8 \mathrm{~h}$ of reflux] afforded multicomponent mixtures of compounds with characteristic for the P-C-N system chemical shifts.

Other $N$-aryl-thioureas led to the corresponding Atc- $\mathrm{AA}^{\mathrm{P}}(\mathrm{OPh})_{2}$ isolated in comparable yields, which during subsequent hydrolytic degradation afforded also $\mathrm{AA}^{\mathrm{P}}$ in high yields (Table 4).

Huber and Middlebrooks ${ }^{22}$ also applied the Birum reaction for the synthesis of $\mathrm{Ala}^{\mathrm{P}}(41 \%)$ and $\operatorname{Pgly}^{\mathrm{P}}(46 \%)$ in accordance with Scheme 9.

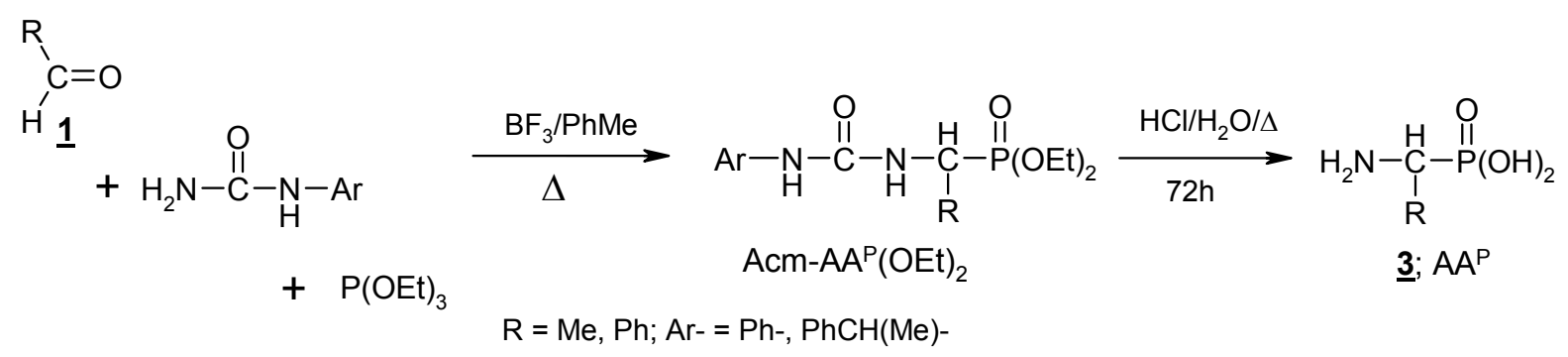

\section{Scheme 9}

Tri-component condensations of aldehydes, triphenyl phosphite and thiourea afforded 1thioureidophosphonates, intermediates in the syntheses of 1-guanidinophosphonic acids. ${ }^{52-54}$ 
Table 4. Bifunctional 1-aminophosphonic acids obtained by degradation of other Atc$\mathrm{AA}^{\mathrm{P}}(\mathrm{OPh})_{2}$

\begin{tabular}{|c|c|c|c|c|c|c|c|c|c|}
\hline \multirow[t]{4}{*}{$\mathrm{AA}^{\mathrm{P}}$} & \multicolumn{3}{|c|}{$\operatorname{Atc}^{-A_{A}}(\mathrm{OPh})_{2}$} & \multicolumn{5}{|c|}{$\mathrm{AA}^{\mathrm{P}}$} & \multirow[t]{4}{*}{ Lit. } \\
\hline & \multirow{3}{*}{$\begin{array}{l}\text { Yield } \\
{[\%]}\end{array}$} & $\begin{array}{l}\text { m.p. } \\
{\left[{ }^{\circ} \mathrm{C}\right]}\end{array}$ & $\begin{array}{c}{ }^{31} \mathrm{P} \mathrm{NMR}^{\mathrm{a}} \\
{[\mathrm{ppm}]}\end{array}$ & \multirow{3}{*}{$\begin{array}{c}\text { Yield } \\
{[\%]} \\
\underline{\mathbf{2}} \rightarrow \underline{\mathbf{3}}\end{array}$} & \multirow{3}{*}{$\begin{array}{l}\text { m.p. } \\
{\left[{ }^{\circ} \mathrm{C}\right]}\end{array}$} & \multicolumn{3}{|c|}{${ }^{31} \mathrm{P}$ NMR [ppm] } & \\
\hline & & $\operatorname{Ttc}-\mathrm{AA}^{\mathrm{P}}(\mathrm{O}$ & h) $)_{2}$ & & & $2 \mathrm{M}$ & $\mathrm{H}_{2} \mathrm{O}$ & $2 \mathrm{M}$ & \\
\hline & & & & & & $\mathrm{HCl}$ & & $\mathrm{NaOH}$ & \\
\hline \multirow[t]{2}{*}{$\mathrm{Ala}^{\mathrm{P}}$} & 85 & $164-166$ & 18.8 & 93 & $275-276$ & 16.8 & 14.3 & 22.3 & \\
\hline & & & & & $275-276$ & & & & 29 \\
\hline \multirow[t]{2}{*}{ Hala $^{\mathrm{P}}$} & 92 & $151-153$ & 17.9 & 96 & $265-266$ & 16.8 & 13.7 & 22.0 & \\
\hline & & & & & $265-266$ & & & & 29 \\
\hline \multirow[t]{2}{*}{$\mathrm{Nval}^{\mathrm{P}}$} & 90 & $159-161$ & 17.8 & 94 & $262-264$ & 16.8 & 13.9 & 22.0 & \\
\hline & & & & & $262-264$ & & & & 29 \\
\hline \multirow[t]{2}{*}{$\mathrm{Val}^{\mathrm{P}}$} & 80 & $170-172$ & 17.1 & 90 & $261-262$ & 15.7 & 13.0 & 21.2 & \\
\hline & & & & & $261-262$ & & & & 29 \\
\hline \multirow[t]{2}{*}{ Nleu $^{P}$} & 88 & $169-171$ & 17.9 & 95 & $262-264$ & 16.5 & 14. & 21.7 & \\
\hline & & & & & $262-264$ & & & & 29 \\
\hline \multirow[t]{3}{*}{ Pgly $^{P}$} & 79 & $160-163$ & 15.1 & 93 & $269-271$ & 12.5 & & 18.0 & \\
\hline & & & & & $269-271$ & & & & 29 \\
\hline & & $\mathrm{Ntc}^{-\mathrm{AA}^{\mathrm{P}}}(\mathrm{O}$ & h) $)_{2}$ & & & & & & \\
\hline \multirow[t]{2}{*}{ Ala $^{\mathrm{P}}$} & 82 & $157-159$ & 18.6 & 93 & $275-276$ & 16.8 & 14.3 & 22.3 & \\
\hline & & & & & $275-276$ & & & & 29 \\
\hline \multirow[t]{2}{*}{ Hala $^{\mathrm{P}}$} & 84 & $165-167$ & 17.6 & 92 & $265-266$ & 16.8 & 13.7 & 22.0 & \\
\hline & & & & & $265-266$ & & & & 29 \\
\hline \multirow[t]{2}{*}{$\mathrm{Nval}^{\mathrm{P}}$} & 86 & $158-159$ & 17.5 & 94 & $262-264$ & 16.8 & 13.9 & 22.0 & \\
\hline & & & & & $262-264$ & & & & 29 \\
\hline \multirow[t]{2}{*}{$\mathrm{Val}^{\mathrm{P}}$} & 73 & $182-184$ & 17.0 & 87 & $261-262$ & 15.7 & 13.0 & 21.2 & \\
\hline & & & & & $261-262$ & & & & 29 \\
\hline \multirow[t]{2}{*}{ Nleu ${ }^{P}$} & 85 & $125-127$ & 17.8 & 91 & $262-264$ & 16.5 & 14. & 21.7 & \\
\hline & & & & & $262-264$ & & & & 29 \\
\hline \multirow[t]{2}{*}{ Pgly $^{P}$} & 80 & $194-195.5$ & 15.2 & 90 & $269-271$ & 12.5 & & 18.0 & \\
\hline & & & & & $269-271$ & & & & 29 \\
\hline
\end{tabular}

${ }^{\mathrm{a}}$ In $\mathrm{CDCl}_{3}$. 


\subsection{Synthesis of trifunctional 1-aminoalkylphosphonic acids}

This section presents the synthetic protocols leading to 1-aminoalkanephosphonic acids bearing the third additional function, including mercapto, alkylthio-, alkylsulfinyl, alkylsulfonyl and sulfonic groups.

2.2.1. Synthesis of sulfur containing 1-aminoalkylphosphonic acids. These syntheses were performed starting from alkylthioacetaldehydes and/or 3-alkylthiopropanals (obtained by addition of corresponding thiols to acrolein) (Scheme 10).

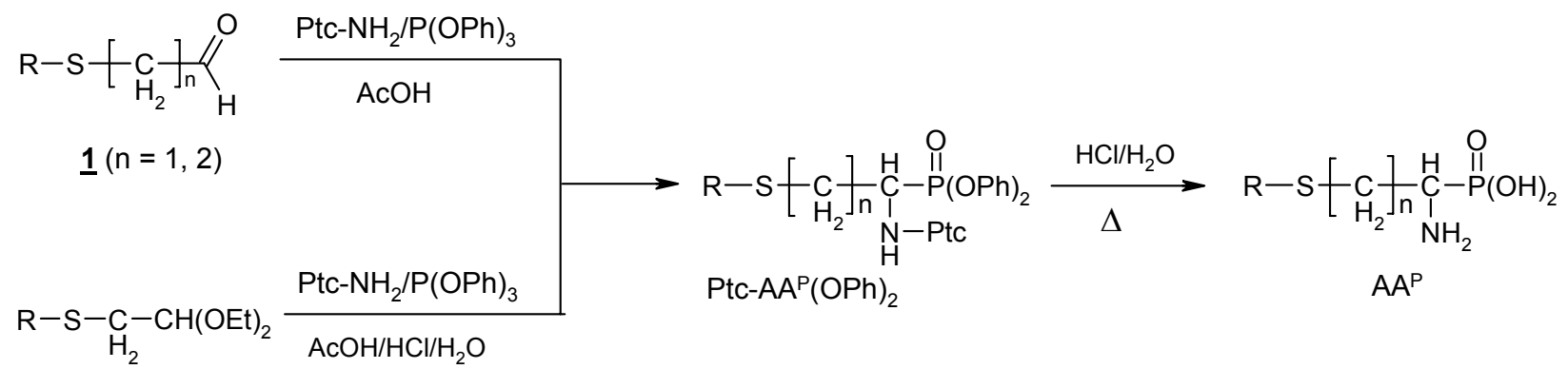

$\underline{1 A}$

\section{Scheme 10}

Alkylthioacetaldehydes were released by hydrolysis of corresponding acetals $\underline{\mathbf{1 A}}$, obtained from thiolates and bromoacetal, and applied for the reaction with $N$-phenylthiourea and triphenyl phosphite without or after prior isolation. The yields and reduced characteristics of obtained 1amino-(2-alkylthioethyl)phosphonic and 1-amino-(3-alkylthiopropyl)phosphonic acids, are summarized in Table 5.

Table 5. Trifunctional sulfur-containing 1-aminothiaalkylphosphonic acids

\begin{tabular}{|c|c|c|c|c|c|c|c|c|c|c|c|}
\hline \multicolumn{6}{|c|}{ Ptc-(R)AA ${ }^{\mathrm{P}}(\mathrm{OPh})_{2}$} & \multicolumn{5}{|c|}{$\mathrm{AA}^{\mathrm{P}}$} & \multirow[t]{3}{*}{ Lit. } \\
\hline \multicolumn{2}{|c|}{$\begin{array}{c}\mathrm{R}= \\
\mathrm{R}^{1}-\mathrm{S}-\left(\mathrm{CH}_{2}\right)_{\mathrm{n}}\end{array}$} & \multirow[t]{2}{*}{$\begin{array}{l}\text { Yield } \\
{[\%]}\end{array}$} & \multirow[t]{2}{*}{$\begin{array}{l}\text { m.p. } \\
{\left[{ }^{\circ} \mathrm{C}\right]}\end{array}$} & \multicolumn{2}{|c|}{$\begin{array}{c}{ }^{31} \mathrm{P} \text { NMR } \\
{[\mathrm{ppm}]}\end{array}$} & \multirow[t]{2}{*}{ Abbrev. } & \multirow[t]{2}{*}{$\begin{array}{c}\text { Yield } \\
{[\%]}\end{array}$} & \multirow[t]{2}{*}{$\begin{array}{l}\text { m.p. } \\
{\left[{ }^{\circ} \mathrm{C}\right]}\end{array}$} & \multicolumn{2}{|c|}{$\begin{array}{c}{ }^{31} \mathrm{P} \text { NMR } \\
{[\mathrm{ppm}]}\end{array}$} & \\
\hline $\mathrm{R}^{1}$ & $\mathrm{n}$ & & & $\mathrm{AcOH}$ & $\mathrm{CDCl}_{3}$ & & & & TFA & $\begin{array}{c}2 \mathrm{M} \\
\mathrm{KOH}\end{array}$ & \\
\hline $\mathrm{Me}$ & 1 & 94 & $\begin{array}{l}136- \\
138\end{array}$ & 15.2 & 15.6 & $\mathrm{MeCys}^{\mathrm{P}}$ & 92 & $\begin{array}{l}258- \\
260\end{array}$ & 14.0 & 18.1 & 55 \\
\hline $\mathrm{Et}$ & 1 & 92 & $\begin{array}{l}135- \\
137\end{array}$ & 15.2 & 15.6 & $\mathrm{EtCys}^{\mathrm{P}}$ & 90 & $\begin{array}{l}257- \\
260\end{array}$ & 13.9 & 18.1 & \\
\hline $\operatorname{Pr}$ & 1 & 91 & $\begin{array}{l}142- \\
144\end{array}$ & 15.2 & 15.6 & $\operatorname{PrCys}^{\mathrm{P}}$ & 91 & $\begin{array}{l}251- \\
252\end{array}$ & 14.1 & 18.1 & \\
\hline
\end{tabular}


Table 5. Continued

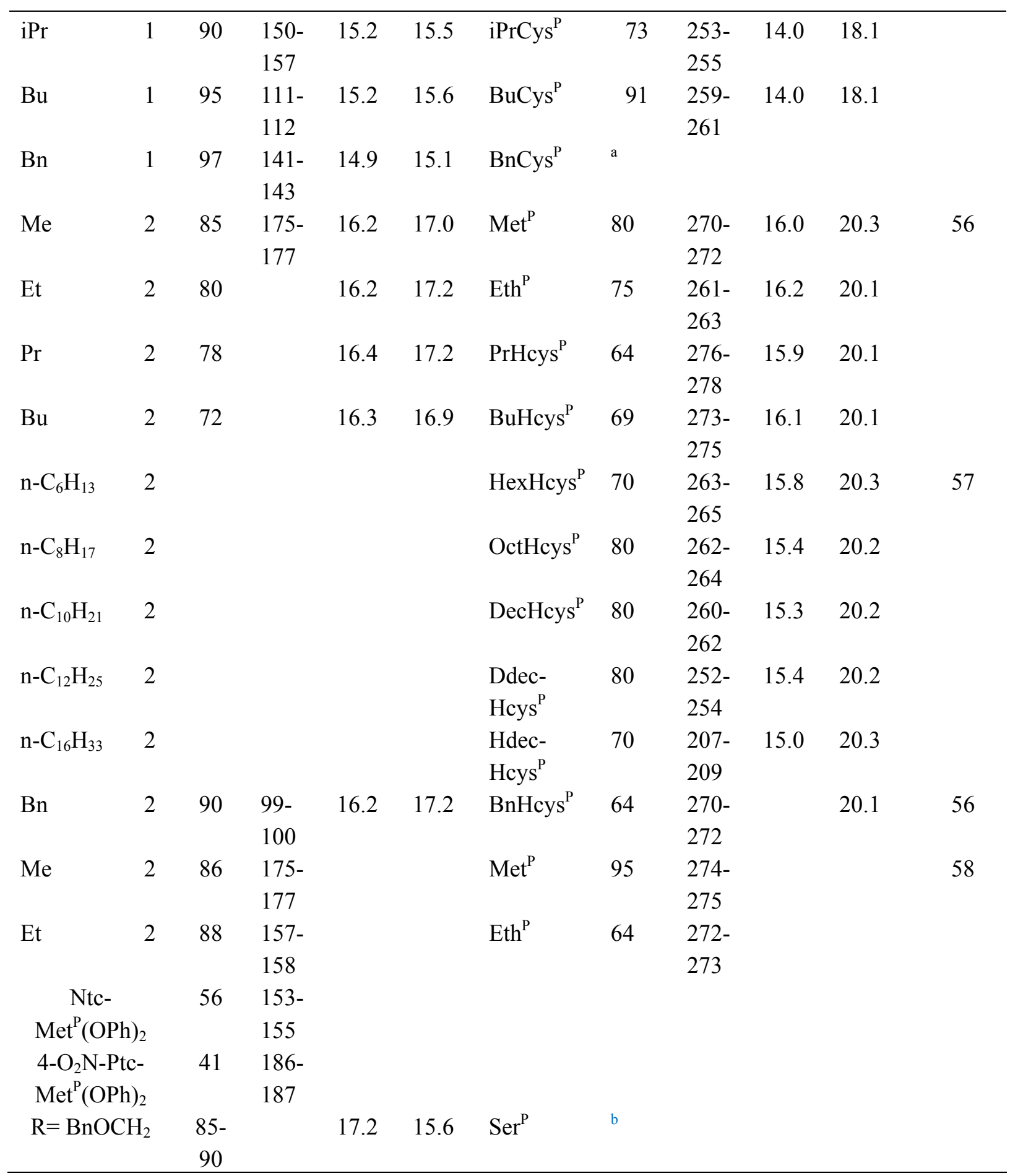

${ }^{\mathrm{a}}$ As the result of the hydrolysis the mixture of $\mathrm{Cys}^{\mathrm{P}}$ and $\operatorname{Ser}^{\mathrm{P}}$ have been observed. ${ }^{\mathrm{b}} \mathrm{As}$ the result of the hydrolysis the mixture of C-N-P compounds (with ${ }^{31} \mathrm{P}(\delta)_{2 \mathrm{M} \mathrm{NaOH}}=18.1(32 \%) ; 14.8(14 \%)$; $13.6(44 \%) \mathrm{ppm})$ have been obtained. 


\section{Diphenyl 2-alkylthio-1-( $N$-phenylthioureido)ethylphosphonates and 3-alkylthio-1-( $N$ -} phenylthioureido)propylphosphonates [Kudzin\&Stec, Synthesis $1980 ;{ }^{56}$ Kudzin, Synthesis $1981^{55}$ ]

Method A. To a solution of triphenyl phosphite $(6.2 \mathrm{~g}, 0.02 \mathrm{~mol})$ and aldehyde $(\underline{\mathbf{1}}, 0.025 \mathrm{~mol})$ in glacial acetic acid $(10 \mathrm{ml})$, powdered $N$-phenylthiourea $(3.02 \mathrm{~g}, 0.02 \mathrm{~mol})$ is added in one portion. The reaction mixture is stirred at room temperature for $0.5 \mathrm{~h}$ and for $0.5 \mathrm{~h}$ at $80^{\circ} \mathrm{C}$ (oil bath temperature). After cooling of the mixture to room temperature, water $(5 \mathrm{ml})$ is added and the solution is maintained at room temperature for $10 \mathrm{~h}$. The precipitate is filtered off, washed with acetic acid/water $(1: 1 ; 2 \times 10 \mathrm{ml})$, dried over potassium hydroxide in an evacuated desiccator, and recrystallized from $\mathrm{CHCl}_{3} / \mathrm{MeOH}$ (Table 1).

Method B. [Kudzin, Synthesis $1981^{55}$ ]: A mixture of the $O, O$-diethyl acetal of the alkanethioacetaldehyde $\underline{\mathbf{1 A}}(0.02 \mathrm{~mol})$, glacial acetic acid/water $(98: 2 ; 10 \mathrm{ml})$ and $p$ toluenesulfonic acid $(0.2 \mathrm{~g})$ are heated under reflux for $5 \mathrm{~min}$. The mixture is diluted with glacial acetic acid $(5 \mathrm{ml})$, cooled to $\sim 50^{\circ} \mathrm{C}$, and $N$-phenylthiourea $(1.6 \mathrm{~g}, 0.01 \mathrm{~mol})$ and triphenyl phosphite $(3.1 \mathrm{~g}, 0.01 \mathrm{~mol})$ are added. The reaction mixture is stirred at $\sim 40^{\circ} \mathrm{C}$ for $2 \mathrm{~h}$. Water $(3-$ $5 \mathrm{ml})$ is added and after $8 \mathrm{~h}$, the crystalline compounds $\mathrm{Ptc}-\mathrm{AA} \mathrm{A}^{\mathrm{P}}(\mathrm{OPh})_{2}$ are separated and purified as described above.

l-Amino-2-alkylthioethylphosphonic and 1-amino-3-alkylthiopropylphosphonic acids $\underline{\mathbf{3}}$ [Kudzin\&Stec, Synthesis 1980 ${ }^{56}$; Kudzin, Synthesis 1981 $^{55}$ ]

Compound Ptc-AA ${ }^{\mathrm{P}}(\mathrm{OPh})_{2}(0.01 \mathrm{~mol})$ is dissolved in glacial acetic acid $(5 \mathrm{ml})$ and $36 \%$ hydrochloric acid $(20 \mathrm{ml})$, and the mixture is heated under reflux for $8 \mathrm{~h}$. The solvents are evaporated under reduced pressure and the residue is dissolved in ethanol $(20 \mathrm{ml})$. The solution is treated with methyloxirane until $\mathrm{pH} 6$ is reached. The precipitate is filtered off, washed with ethanol, and dried under vacuum over potassium hydroxide. Recrystallization from ethanol/water gives the pure aminoalkylphosphonic acid.

Since mercaptoethanal as well as 3-mercaptopropanal - carbonyl precursors of $\mathrm{Cys}^{\mathrm{P}}$ and $\mathrm{Hcys}^{\mathrm{P}}$ do not exist in the free forms, we used $S$-protected $\left[\mathrm{Ac}, \mathrm{tBu},(\mathrm{BuO})_{3} \mathrm{Si}\right]$ thioalkanals. The obtained corresponding Ptc- $\mathrm{AA}^{\mathrm{P}}(\mathrm{OPh})_{2}$ derivatives, underwent the acidic-hydrolytic degradation with simultaneous deprotection of the phosphonic, amino and thiol functions affording corresponding 1-amino-2-mercaptoethylphosphonic acid $\left[\mathrm{Cys}^{\mathrm{P}}\right]$ or 1-amino-3-mercaptopropylphosphonic acid $\left[\mathrm{HCys}^{\mathrm{P}}\right]$ in high ${ }^{31} \mathrm{P}$ NMR yields (Scheme 11).

Because of difficulties in isolation of $\mathrm{Cys}^{\mathrm{P}}$ and/or $\mathrm{HCys}^{\mathrm{P}}$ from their reaction mixtures these amino acids were converted into insoluble disulfide forms $\left[\mathrm{Cys}^{\mathrm{P}}\right]_{2}{ }^{55}$ and $\left[\mathrm{Hcys}^{\mathrm{P}}\right]_{2}{ }^{56}$ or precipitated in the form of their mercury salts, and subsequently regenerated by saturating with hydrogen sulfide. ${ }^{59}$

Thus, Cys $^{\mathrm{P}}$ by pretreatment with aqueous mercury sulfate afforded the crystalline salt Cys ${ }^{\mathrm{P}} \cdot \mathrm{Hg}(\mathrm{II})$ which, according to microanalysis, possesses the formula $\mathrm{C}_{2} \mathrm{H}_{6} \mathrm{NO}_{3} \mathrm{PS} \times \mathrm{Hg}(\mathrm{II}) \times \mathrm{H}_{2} \mathrm{O}$. Treatment of a suspension of $\mathrm{Cys}^{\mathrm{P}} \cdot \mathrm{Hg}$ (II) in water with hydrogen sulfide liberates free phosphonocysteine $\left(\mathrm{Cys}^{\mathrm{P}}\right)$ which upon ion-exchange chromatography was isolated in crystalline form (platelets). A similar sequence can be applied to the synthesis of phosphonohomocysteine 
$\left(\right.$ Hcys $\left.^{\mathrm{P}}\right)$ starting from 3-( $t$-butylthio)propanal. In this case, the mercury salt Hcys ${ }^{\mathrm{P}} \cdot \mathrm{Hg}(\mathrm{II})$ used for the isolation of Hcys $^{\mathrm{P}}$ is assumed to have the formula $\mathrm{C}_{6} \mathrm{H}_{20} \mathrm{~N}_{2} \mathrm{O}_{6} \mathrm{P}_{2} \mathrm{~S}_{2} \mathrm{Hg}_{3}$.

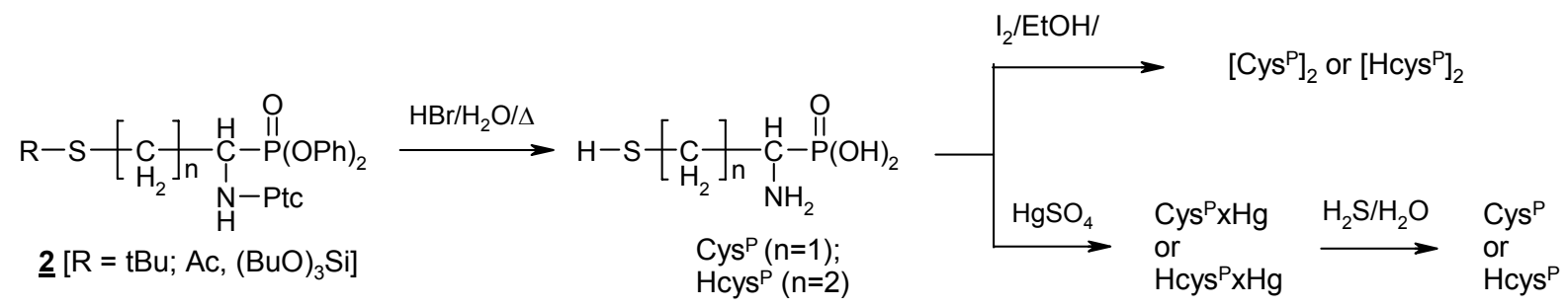

\section{Scheme 11}

Phosphonocystine $\left(\left[\mathrm{Cys}^{\mathrm{P}}\right]_{2}\right)$ [Kudzin, Synthesis $\left.1981^{55}\right]$ and phosphonohomocystine $\left(\left[\text { Hcys }^{\mathrm{P}}\right]_{2}\right.$ ) [Kudzin\&Stec, Synthesis $\left.\mathbf{1 9 8 0}^{56}\right]$ :

To a solution of Ptc-(t-Bu)Cys ${ }^{\mathrm{P}}(\mathrm{OPh})_{2}$ or Ptc-(R)Hcys ${ }^{\mathrm{P}}(\mathrm{OPh})_{2}$, [R=tBu-, Ac- or $\left.(\mathrm{tBuO})_{3} \mathrm{Si}-\right](0.01$ $\mathrm{mol})$ in glacial acetic acid $(10 \mathrm{ml})$ aqueous hydrobromic acid $(d=1.38 \mathrm{~g} / \mathrm{ml}, 20 \mathrm{ml})$ is added and the mixture is heated under reflux for $14 \mathrm{~h}$. The solvents are evaporated under reduced pressure. The residue is dissolved in ethanol $(10 \mathrm{ml})$ and treated with a solution of iodine $(1.4 \mathrm{~g}, 0.052$ $\mathrm{mol})$ in ethanol $(10 \mathrm{ml})$. The mixture is stirred for $15 \mathrm{~min}$ and propylene oxide is added until $\mathrm{pH}$ 6 is reached. The precipitated crude phosphonocystine $\left[\mathrm{Cys}^{\mathrm{P}}\right]_{2}$ or phosphonohomocystine $\left[\text { Hcys }^{\mathrm{P}}\right]_{2}$ is filtered off, washed with ethanol $(10 \mathrm{ml})$ and water $(10 \mathrm{ml})$, and dissolved in ethanol/water/36\% hydrochloric acid (10:10:1.5). The amino acids are again precipitated with propylene oxide, filtered off, washed with ethanol and water, and dried in vacuum over potassium hydroxide. Yields and physical yields are collected in Table 6.

Phosphonocysteine $\left(\mathrm{Cys}^{\mathrm{P}}\right)$ and phosphonohomocysteine (HCys ${ }^{\mathrm{P}}$ ) [Kudzin\&Stec, Synthesis $\mathbf{1 9 8 3}^{59}$ ]:

Triphenyl phosphite $(18.6 \mathrm{~g}, 0.06 \mathrm{~mol})$ is added in one portion to a stirred solution of the aldehyde t-butylthioethanal or 3-(t-butylthio)propanal $(0.05 \mathrm{~mol})$ and $N$-phenylthiourea $(9.06 \mathrm{~g}$, $0.06 \mathrm{~mol})$ in glacial acetic acid $(50 \mathrm{ml})$. Stirring is continued for $1 \mathrm{~h}$, the mixture allowed to stand at room temperature over night, and then diluted with water $(5 \mathrm{ml})$. After $2 \mathrm{~h}$, the precipitated phosphonates Ptc- $(\mathrm{tBu}) \mathrm{Cys}^{\mathrm{P}}(\mathrm{OPh})_{2}$ or Ptc- $(\mathrm{tBu}) \mathrm{HCys}^{\mathrm{P}}(\mathrm{OPh})_{2}$ is filtered off, washed with acetic $\mathrm{acid} /$ water and. The crude phosphonate is dissolved in a mixture of glacial acetic acid (50 $\mathrm{ml})$ and $40 \%$ hydrobromic acid $(100 \mathrm{ml})$ and this solution is heated at reflux temperature for $16 \mathrm{~h}$. The resultant mixture is cooled to room temperature, diluted with water $(100 \mathrm{ml})$, extracted with benzene $(2 \times 50 \mathrm{ml})$, and evaporated to dryness under reduced pressure. The solid residue is dissolved in methanol (125 ml), and a solution of mercury(II) sulfate (30 g) in sulfuric acid (30 $\mathrm{g})$ and water $(125 \mathrm{ml})$ is added. After $3 \mathrm{~h}$, the precipitated salt $\left(\mathrm{Cys}^{\mathrm{P}}\right) \times \mathrm{Hg}(\mathrm{II})$ or $\left(\mathrm{HCys}^{\mathrm{P}}\right) \times \mathrm{Hg}(\mathrm{II})$ is isolated by suction, washed with water $(2 \times 30 \mathrm{ml})$, and dried to constant weight in a dessicator over solid phosphorus pentoxide and potassium hydroxide under reduced pressure. The salt $\left(\mathrm{Cys}^{\mathrm{P}}\right) \times \mathrm{Hg}(\mathrm{II})$ or $\left(\mathrm{HCys}^{\mathrm{P}}\right) \times \mathrm{Hg}(\mathrm{II})(10 \mathrm{~g})$ is suspended in water $(100 \mathrm{ml})$. This suspension is saturated with hydrogen sulfide and stirred at room temperature for $3 \mathrm{~h}$. The precipitated solid is 
filtered off, washed with water $(2 \times 30 \mathrm{ml})$, and the combined filtrate is concentrated in vacuo to a volume of $\sim 25 \mathrm{ml}$. The solution is passed through a Dowex $50 \mathrm{~W} \times 2$ column and the fractions containing $\mathrm{Cys}^{\mathrm{P}}$ or $\mathrm{HCys}^{\mathrm{P}}$ (ninhydrin or thiomercurimetric test) are collected. The combined fractions containing $\mathrm{Cys}^{\mathrm{P}}$ or $\mathrm{HCys}^{\mathrm{P}}$, respectively, are concentrated under reduced pressure to a volume of $\sim 5 \mathrm{ml}$ and amino acids $\mathrm{Cys}^{\mathrm{P}}$ or $\mathrm{HCys}^{\mathrm{P}}$ are precipitated with ethanol $(25 \mathrm{ml})$.

Table 6. Trifunctional thiolic 1-aminoalkylphosphonic acids

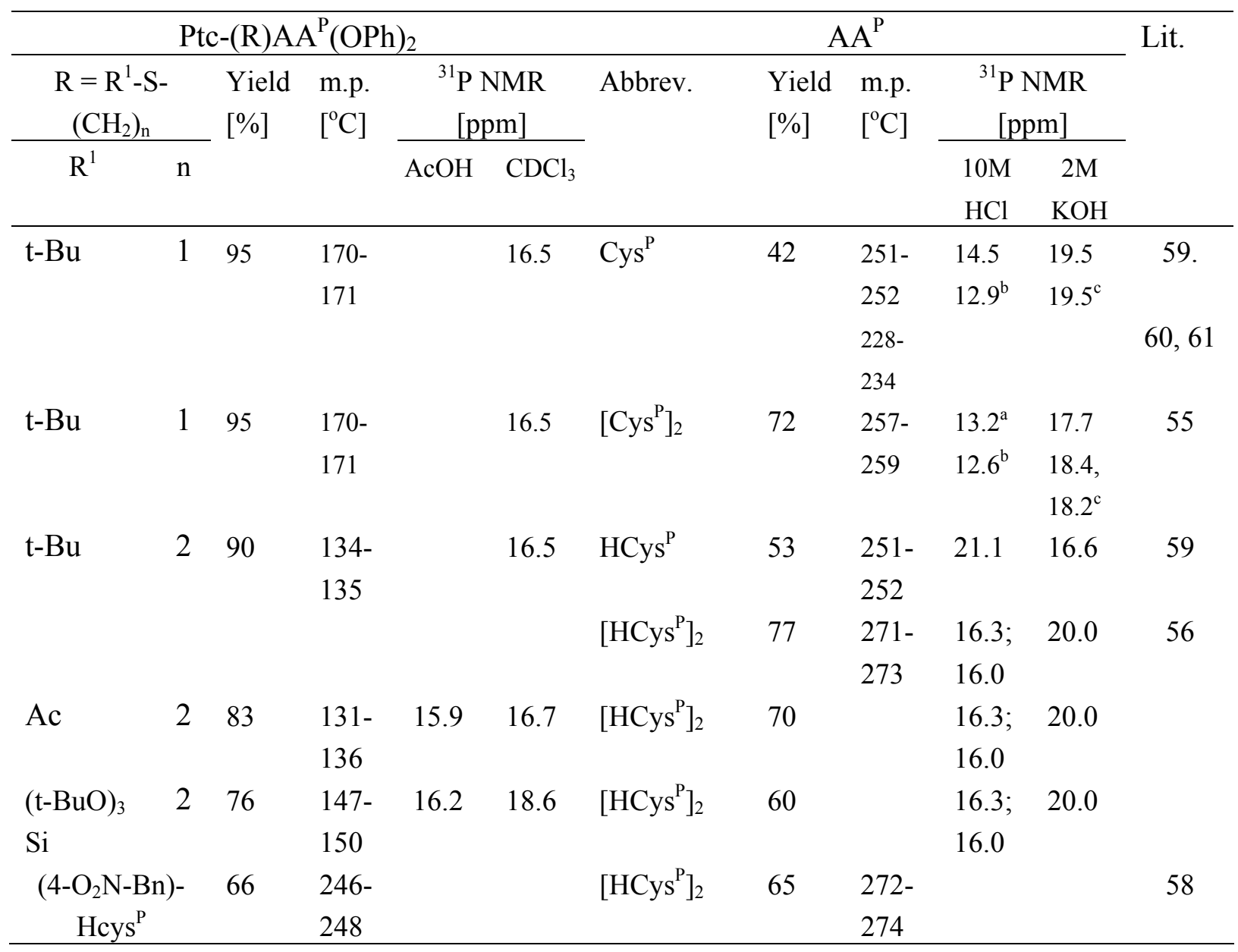

${ }^{\mathrm{a}}$ In TFA. ${ }^{\mathrm{b}}$ In $2 \mathrm{M} \mathrm{HCl} .{ }^{\mathrm{c}}$ In $2 \mathrm{M} \mathrm{NaOH}$.

For the preparation of phosphonohomocystine Tishler and co-workers proposed method presented schematically on Scheme 12.

2.2.1.1. Functionalization of sulfur containing 1-aminoalkylphosphonic acids. Oxidation of phosphonic analogues of the thiolo-amino acids, namely $\mathrm{Cys}^{\mathrm{P}}$ and/or $\mathrm{Hcys}^{\mathrm{P}}$ afford, depending on the applied conditions, disulfide derivatives $\left[\mathrm{Cys}^{\mathrm{P}}\right]_{2}{ }^{55}$ and $\left[\mathrm{Hcys}^{\mathrm{P}}\right]_{2}{ }^{56}$ or sulfonic derivatives Cys ${ }^{\mathrm{P}}$

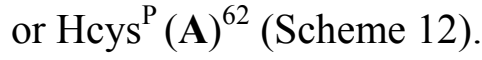




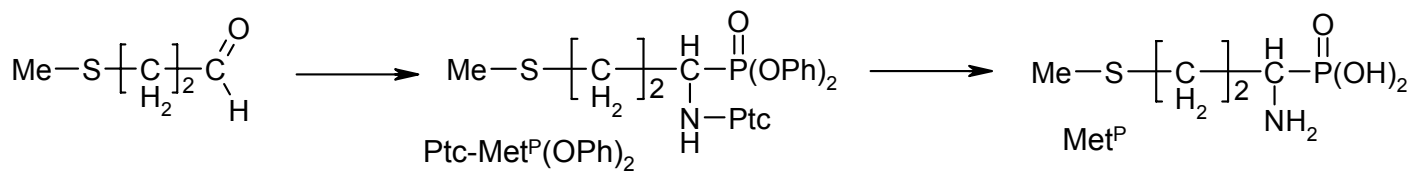

$$
\begin{aligned}
& \mathrm{O}_{2} \mathrm{~N} \longrightarrow \mathrm{Cl}
\end{aligned}
$$

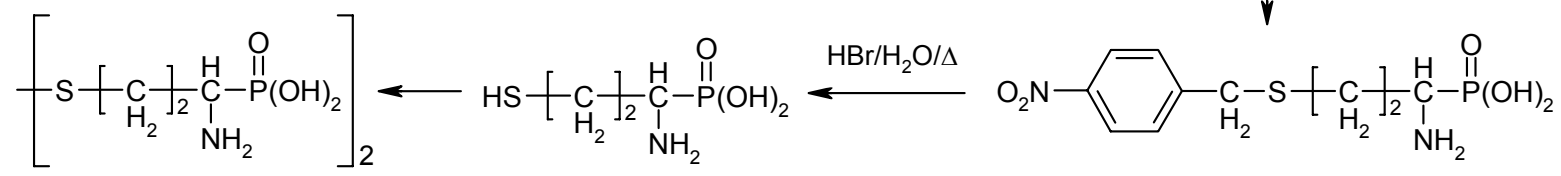

$$
\begin{aligned}
& \text { HCys } \left.^{\mathrm{P}}\right]_{2}
\end{aligned}
$$

\section{Scheme 12}

The bromine-induced oxidation of phosphonohomocysteine Hcys ${ }^{\mathrm{P}}$ was found to occur in a far more complicated manner. The reaction occurred with splitting of the P-C bond, unless it was carried out in a strong acidic medium $(5 \mathrm{M} \mathrm{HCl})$ (the bromine-induce dephosphonylation of 1aminoalkylphosphonic acids will be discussed in a separate paper ${ }^{63}$ ). In such conditions, the oxidation proceeded gradually with the formation of a mixture of intermediary derivatives, slowly rearranging into the final $\mathrm{HCySO}_{3} \mathrm{H}^{\mathrm{P}}$ (Scheme 13). ${ }^{62}$

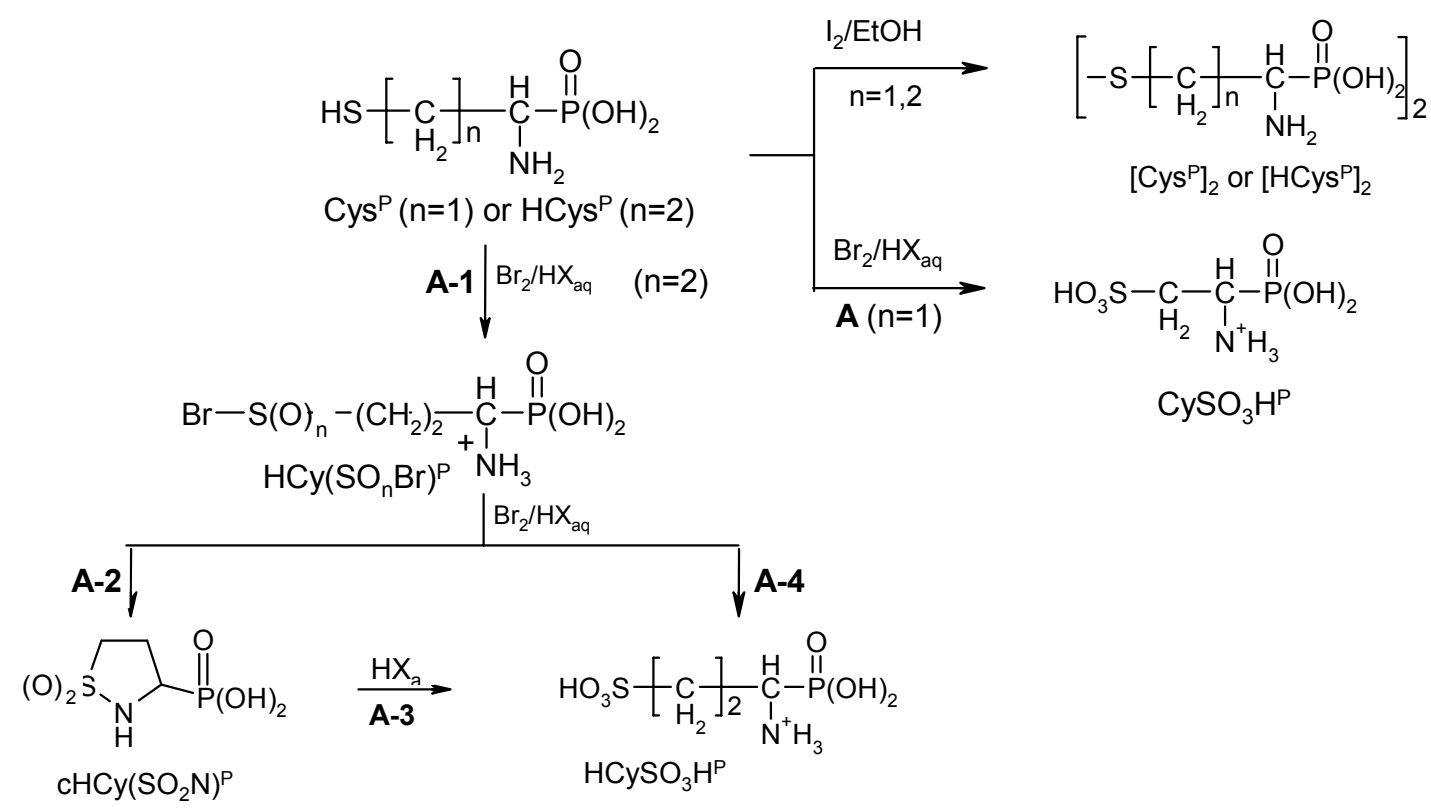

A-1 - bromine promoted oxidation of $\operatorname{Hcys}^{\mathrm{P}}\left\{\operatorname{Hcys}^{\mathrm{P}} \rightarrow \operatorname{Hcy}(\mathrm{SBr})^{\mathrm{P}}\left[\mathrm{n}=0 ; \delta\left({ }^{31} \mathrm{P}\right)_{2 \mathrm{M} \mathrm{HCl}}=15.7\right.\right.$ $\mathrm{ppm}] \rightarrow \mathrm{Hcy}[\mathrm{S}(\mathrm{O}) \mathrm{Br}]^{\mathrm{P}}\left[\mathrm{n}=1 ; \delta\left({ }^{31} \mathrm{P}\right)_{2 \mathrm{M} \mathrm{HCl}}=14.7 \mathrm{ppm}\right] \rightarrow \operatorname{Hcy}\left[\mathrm{S}(\mathrm{O})_{2} \mathrm{Br}\right]^{\mathrm{P}}\left[\mathrm{n}=2 ; \delta\left({ }^{31} \mathrm{P}\right)_{2 \mathrm{M} \mathrm{HCl}}=\right.$ $13.9 \mathrm{ppm}]\}$; A-2 - cyclization of $\mathrm{Hcy}\left[\mathrm{S}(\mathrm{O})_{2} \mathrm{Br}\right]^{\mathrm{P}}$ to $\mathrm{cHcy}\left[\mathrm{S}(\mathrm{O})_{2} \mathrm{~N}\right]^{\mathrm{P}}\left[\delta\left({ }^{31} \mathrm{P}\right)_{2 \mathrm{M} \mathrm{HCl}}=20.1 \mathrm{ppm}\right]$; $\mathbf{A}-$ 3 - hydrolysis of the sulfonamide bond $\left\{\mathrm{cHcy}\left[\mathrm{S}(\mathrm{O})_{2} \mathrm{~N}\right]^{\mathrm{P}} \rightarrow \mathrm{HcySO}_{3} \mathrm{H}^{\mathrm{P}}\right\} ; \mathbf{A}-\mathbf{4}-$ hydrolysis $\mathrm{Hcy}\left[\mathrm{S}(\mathrm{O})_{2} \mathrm{Br}\right]^{\mathrm{P}}$ to $\mathrm{HcySO}_{3} \mathrm{H}^{\mathrm{P}}\left[\delta\left({ }^{31} \mathrm{P}\right)_{2 \mathrm{M} \mathrm{HCl}}=15.1 \mathrm{ppm}\right]$.

\section{Scheme 13}




\section{Preparation of phosphonocysteic acid $\left[\mathrm{CySO}_{3} \mathbf{H}^{\mathrm{P}}\right.$ ] [Kudzin et al., Pol. J. Chem. $\mathbf{2 0 0 5}^{62}$ ]}

Phosphonocysteine (1mmol; $0.16 \mathrm{~g}$ ) was dissolved in $2 \mathrm{M}$ hydrochloric acid $(2.5 \mathrm{ml})$ and treated drop by drop with stirring at ambient temperature with bromine $(3.3 \mathrm{mmol} ; 0.5 \mathrm{~g})$. The mixture was allowed to react for $24 \mathrm{~h}$ and concentrated to dryness under reduced pressure at $50^{\circ} \mathrm{C}(10$ $\mathrm{mm} \mathrm{Hg}$ and $0.2 \mathrm{~mm} \mathrm{Hg})$ affording the desired product $\mathrm{CySO}_{3} \mathrm{H}^{\mathrm{P}}(0.20 \mathrm{~g} ; 97.5 \%)$ of analytical purity.

Preparation of phosphonohomocysteic acid $\left[\mathrm{HCySO}_{3} \mathbf{H}^{\mathbf{P}}\right]$ [Kudzin et al., Pol. J. Chem. $\mathbf{2 0 0 5}^{62}$ ]:

Phosphonohomocysteine $(2.9 \mathrm{mmol} ; 0.50 \mathrm{~g})$ in $5 \mathrm{M}$ hydrochloric acid $(4 \mathrm{ml})$ solution was cooled to ca. $0^{\circ} \mathrm{C}$ (dry ice/acetone bath) and treated drop by drop with stirring with bromine $(9.57 \mathrm{mmol}$; $1.53 \mathrm{~g}$ ). The mixture was allowed to react for $24 \mathrm{~h}$, heated under reflux temperature for $2 \mathrm{~h}$ and concentrated to dryness under reduced pressure at $50^{\circ} \mathrm{C}(10 \mathrm{~mm} \mathrm{Hg}$ and $0.2 \mathrm{~mm} \mathrm{Hg})$ affording the desired product $\mathrm{HCySO}_{3} \mathrm{H}^{\mathrm{P}}(0.61 \mathrm{~g} ; 96 \%)$ of analytical purity.

In a number of works, modifications of the thioether function of 1-amino-n-thiaalkylphosphonic acids were conducted, affording corresponding sulfinyl- and/or sulfonyl, ${ }^{57,58,64}$ as well as trimethylsulfonium derivatives. ${ }^{58,65}$

The synthesis of the sulfinyl $\underline{\mathbf{3 B}}$ and sulfonyl $\underline{\mathbf{3 C}}$ derivatives of the sulfur-containing amino acids $\underline{\mathbf{3 A}}$ elaborated by us, was based on the selective oxidation of the latter compounds.

Hydrogen peroxide was found to be useful as a selective oxidant in the case of simple sulfides. ${ }^{66}$ However, its application for the oxidation of sulfides bearing an acidic function is limited by the fact that, in the presence of such a group, the subsequent oxidation of the sulfoxides initially formed to sulfones is facilitated. For this reason, the oxidations of amino acids related to methionine have been carried out using hydrogen peroxide in nearly stoichiometric amounts and/or carrying out the reaction at low temperature with careful TLC monitoring of the reaction's progress. ${ }^{58,67}$

We have found, moreover, that the addition of DMSO, used in excess to the oxidant, to the reaction mixture of the amino acids $\underline{\mathbf{3 A}}$, and hydrogen peroxide, enables the selective course of the oxidation $\underline{\mathbf{3 A}} \rightarrow \underline{\mathbf{3 B}}$, at ambient temperature, in spite of the large excess of oxidant used. The opposite effect was observed with the use of selenium (IV) dioxide ${ }^{66}$ as a catalyst. The acceleration of the second oxidation stage $(\underline{\mathbf{3 B}} \rightarrow \underline{\mathbf{3 C}})$ results in a fast and almost quantitative conversion of the amino acids $\underline{\mathbf{3 A}}$ to their sulfonyl derivatives $\underline{\mathbf{3 C}}(\underline{\mathbf{3 A}} \rightarrow \underline{\mathbf{3 B}} \rightarrow \underline{\mathbf{3 C}})$.

The latter reagent has also been successfully applied in the oxidation system $\mathrm{TFA}-\mathrm{H}_{2} \mathrm{O}_{2}-\mathrm{SeO}_{2}$ for the oxidation of surfactant derivatives of 1-aminothiaalkylphosphonic acids to their sulfonyl analogs. ${ }^{57}$ The yields and physical and analytical properties of the amino acids $\underline{\mathbf{3 B}}$ and $\underline{\mathbf{3 C}}$ are summarized in Table 7.

$S$-Alkylphosphonomethionines $\underline{\mathbf{3 E}}(\mathrm{n}=2)$ were found to be unstable in basic conditions. They were converted into phosphonohomoserine $\left[\mathrm{Hser}^{\mathrm{P}}\right]$ via elimination of corresponding thioether molecules. ${ }^{68,69}$ 1-Amino-3-sulfonylalkylphosphonic acids $\underline{\mathbf{3 C}}-$ were converted into sulfoxyiminium derivatives $\underline{\mathbf{B D}}^{70}$ (Scheme 14). 


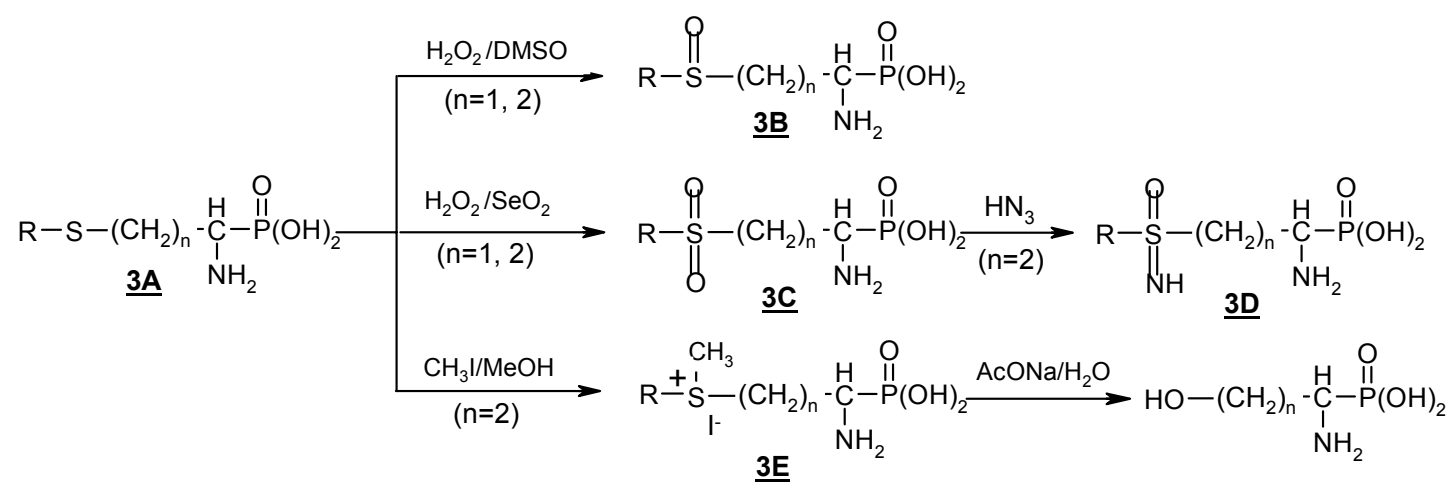

Scheme 14

Table 7. Sulfinyl, sulfonyl and sulfonic derivatives of 1-aminothioalkylphosphonic acids

\begin{tabular}{|c|c|c|c|c|c|c|c|}
\hline \multicolumn{3}{|c|}{$\mathrm{AA}^{\mathrm{P}}$} & \multirow{3}{*}{$\begin{array}{l}\text { Yield } \\
{[\%]}\end{array}$} & \multirow{3}{*}{$\begin{array}{l}\text { m.p. } \\
{\left[{ }^{\circ} \mathrm{C}\right]}\end{array}$} & \multicolumn{2}{|c|}{${ }^{31} \mathrm{P}$ NMR $[\mathrm{ppm}]$} & \multirow[t]{3}{*}{ Lit. } \\
\hline \multicolumn{2}{|c|}{$\mathrm{R}^{1}-\mathrm{S}(\mathrm{O})-\left(\mathrm{CH}_{2}\right)_{\mathrm{n}}$} & \multirow[t]{2}{*}{ Abbrev. } & & & \multirow[t]{2}{*}{$2 \mathrm{M} \mathrm{NaOH}$} & \multirow[t]{2}{*}{$2 \mathrm{M} \mathrm{HCl}$} & \\
\hline $\mathrm{R}^{1}$ & $\mathrm{n}$ & & & & & & \\
\hline $\mathrm{Me}$ & 1 & $\operatorname{Mcys}(\mathrm{SO})^{\mathrm{P}}$ & 88 & 194-196 & $16.5 ; 17.1$ & $10.9 ; 11.2$ & 64 \\
\hline $\mathrm{Et}$ & 1 & $\operatorname{Ecys}(\mathrm{SO})^{\mathrm{P}}$ & 86 & $192-196$ & $16.6 ; 17.3$ & $10.9 ; 11.3$ & \\
\hline \multirow[t]{2}{*}{$\mathrm{Me}$} & 2 & $\operatorname{Met}(\mathrm{SO})^{\mathrm{P}}$ & 85 & $185-187$ & $19.0 ; 19.5$ & 14.0 & \\
\hline & & & & $188-190$ & & & 58 \\
\hline $\mathrm{Et}$ & 2 & $\operatorname{Eth}(\mathrm{SO})^{\mathrm{P}}$ & 93 & 194-196 & 19.4 & 14.0 & 64 \\
\hline Hex & 2 & $\operatorname{Hex}(\mathrm{SO})^{\mathrm{P}}$ & 83 & $234-236$ & 19.2 & $14.5^{\mathrm{a}}$ & 57 \\
\hline Oct & 2 & $\operatorname{Oct}(\mathrm{SO})^{\mathrm{P}}$ & 86 & $200-202$ & 19.2 & $14.5^{\mathrm{a}}$ & \\
\hline Dec & 2 & $\operatorname{Dec}(\mathrm{SO})^{\mathrm{P}}$ & 81 & $197-200$ & 19.2 & $14.6^{\mathrm{a}}$ & \\
\hline Ddec & 2 & $\operatorname{Ddec}(\mathrm{SO})^{\mathrm{P}}$ & 85 & $188-191$ & 19.3 & $14.6^{\mathrm{a}}$ & \\
\hline Hdec & 2 & $\operatorname{Hdec}(\mathrm{SO})^{\mathrm{P}}$ & 83 & $183-185$ & 19.0 & $14.7^{\mathrm{a}}$ & \\
\hline \multicolumn{8}{|c|}{$\mathrm{R}^{1}-\mathrm{S}(\mathrm{O})_{2}-\left(\mathrm{CH}_{2}\right)_{\mathrm{n}}$} \\
\hline $\mathrm{R}^{1}$ & $\mathrm{n}$ & & & & & & \\
\hline $\mathrm{Me}$ & 1 & $\operatorname{Mcys}(\mathrm{SO})_{2}{ }^{\mathrm{P}}$ & 90 & $250-252$ & 16.1 & 10.1 & 64 \\
\hline $\mathrm{Et}$ & 1 & $\operatorname{Ecys}(\mathrm{SO})_{2}{ }^{\mathrm{P}}$ & 89 & $258-260$ & 16.2 & 10.2 & \\
\hline \multirow[t]{2}{*}{$\mathrm{Me}$} & 2 & $\operatorname{Met}(\mathrm{SO})_{2}{ }^{\mathrm{P}}$ & 86 & $254-256$ & 19.0 & 13.6 & \\
\hline & & & & $258-260$ & & & 58 \\
\hline Et & 2 & $\operatorname{Eth}\left(\mathrm{SO}_{2}\right)^{\mathrm{P}}$ & 93 & $255-257$ & 19.0 & 13.6 & 64 \\
\hline Hex & 2 & $\operatorname{Hex}\left(\mathrm{SO}_{2}\right)^{\mathrm{P}}$ & 92 & $264-266$ & 18.7 & $14.3^{\mathrm{a}}$ & 57 \\
\hline Oct & 2 & $\operatorname{Oct}\left(\mathrm{SO}_{2}\right)^{\mathrm{P}}$ & 96 & $252-254$ & 18.8 & $14.1^{\mathrm{a}}$ & \\
\hline Dec & & $\operatorname{Dec}\left(\mathrm{SO}_{2}\right)^{\mathrm{P}}$ & 93 & $236-238$ & 18.9 & $14.2^{\mathrm{a}}$ & \\
\hline Ddec & 2 & $\operatorname{Ddec}\left(\mathrm{SO}_{2}\right)^{\mathrm{P}}$ & 97 & $237-239$ & 18.9 & $14.2^{\mathrm{a}}$ & \\
\hline Hdec & 2 & $\operatorname{Hdec}\left(\mathrm{SO}_{2}\right)^{\mathrm{P}}$ & 98 & $247-249$ & 18.9 & $14.2^{\mathrm{a}}$ & \\
\hline \multicolumn{2}{|c|}{$\mathrm{HO}-\mathrm{S}(\mathrm{O})_{2}-\mathrm{CH}_{2}$} & Cys ${ }^{\mathrm{P}} \mathrm{A}$ & $97(100)$ & $250-256$ & 18.0 & 11.9 & 62 \\
\hline \multicolumn{2}{|c|}{$\mathrm{HO}-\mathrm{S}(\mathrm{O})_{2}-\left(\mathrm{CH}_{2}\right)_{2}$} & $\mathrm{HCys}^{\mathrm{P}} \mathrm{A}$ & $96(100)$ & $232-238$ & 20.5 & 14.8 & \\
\hline
\end{tabular}

${ }^{\mathrm{a}}$ In TFA. 
Preparation of the sulfinyl derivatives $\underline{3 \mathrm{~B}}$ of the amino acids $\underline{\mathbf{3 A}}$. General procedure [Kudzin et al., Heteroatom Chem. 1994 ${ }^{64}$ ]:

Each of the amino acids $\underline{\mathbf{3 A}}(5 \mathrm{mmol})$ was added in one portion into a cooled $\left(10^{\circ} \mathrm{C}\right)$ and wellstirred mixture of hydrogen peroxide (30\% aq., $2 \mathrm{ml})$, water $(2 \mathrm{ml})$, and dimethyl sulfoxide (3 $\mathrm{ml}$ ), and the reaction mixture was stirred for $0.5 \mathrm{~h}$ at room temperature. After dilution with acetone $(30 \mathrm{ml})$, the mixtures were left in the refrigerator for $2 \mathrm{~h}$. The solvent layer was removed, and the residue was dissolved in distilled water $(25 \mathrm{ml})$. The aqueous solutions of the amino acids $\underline{\mathbf{B B}}$ were passed through a Dowex $50 \mathrm{~W} \times 2$ column, the fractions containing the amino acids (ninhydrin test) being collected and evaporated to dryness. The amino acids $\underline{\mathbf{3 B}}$ were recrystallized from water-ethanol mixtures.

Preparation of the sulfonyl derivatives $\underline{3 \mathrm{C}}$ of the amino acids $\underline{\mathbf{3 A}}$. General procedure[Kudzin et al., Heteroatom Chem. 1994 ${ }^{\frac{3 C}{64}}$ :

Each of the amino acids $\underline{\mathbf{3 A}}(5 \mathrm{mmol})$ was added in one portion into a cooled $\left(1 \mathrm{O}^{\circ} \mathrm{C}\right)$ and wellstirred solution of hydrogen peroxide (30\% aq., $2 \mathrm{ml})$, water $(3 \mathrm{ml})$, and selenic acid $(0.01 \mathrm{~g})$. The reaction mixture was stirred at room temperature for $0.5 \mathrm{~h}$, diluted with acetone $(30 \mathrm{ml})$, and left in the refrigerator for $2 \mathrm{~h}$. The precipitated amino acids $\underline{\mathbf{3 C}}$ were isolated by decantation, dissolved in distilled water $(25 \mathrm{ml})$, and purified on a Dowex $5 \mathrm{OW} \times 2$ column. The fractions containing the amino acids (ninhydrin test) were collected and evaporated to dryness, and the pure compounds $\underline{\mathbf{3 C}}$ were recrystallized from water/ethanol mixtures.

2.2.2. Synthesis of 1-aminoalkyldiphosphonic acids. 1-Aminoalkyldiphosphonic acids phosphonic analogs of protein acidic amino acids and their homologs were also synthesized by the Ptc-aminophosphonate method.

Thus, the condensation of the corresponding terminal phosphonoalkanals $\mathbf{1}$ ( $\mathrm{n}=1,2$ and 3 ) with $N$-phenylthiourea and triphenyl phosphite, and subsequent acidic degradation of temporary formed corresponding thioureidoalkylphosphonates Ptc-AA ${ }^{\alpha \mathrm{P}}(\mathrm{OPh})_{2}{ }^{\omega \mathrm{P}}(\mathrm{OEt})_{2}$ afforded the title $\mathrm{AA}^{\alpha \mathrm{P}, \omega \mathrm{P}}$ (Scheme 15, Table 8).

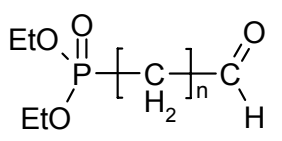

$\underline{1}(n=1,2,3)$

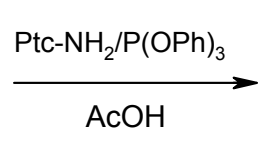

$\left.\operatorname{Ptc}^{-A A^{\alpha P}(O P h}\right)_{2}{ }^{\omega P}(\mathrm{OEt})_{2}$

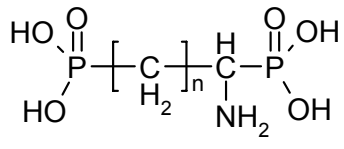

$A A^{P, P}$

\section{Scheme 15}

Terminal phosphonoalkanals $\underline{\mathbf{1}}(\mathrm{n}=1-3)$ were obtained in Arbuzov reaction from corresponding halogenoacetals and triethyl phosphite, and subsequent hydrolysis of formed $\omega$ phosphonyloacetals. $^{71}$ 
Table 8. Bisacidic 1-aminoalkylphosphonic acids

\begin{tabular}{|c|c|c|c|c|c|c|c|c|}
\hline \multirow[t]{3}{*}{$\mathrm{AA}^{\mathrm{P}}$} & \multicolumn{3}{|c|}{ Ptc-AA ${ }^{\mathrm{P}}(\mathrm{OPh})_{2}$} & \multicolumn{4}{|c|}{$\mathrm{AA}^{\mathrm{P}}$} & \multirow[t]{3}{*}{ Lit. } \\
\hline & \multirow{2}{*}{$\begin{array}{l}\text { Yield } \\
{[\%]}\end{array}$} & \multirow{2}{*}{$\begin{array}{l}\text { m.p. } \\
{\left[{ }^{\circ} \mathrm{C}\right]}\end{array}$} & \multirow{2}{*}{$\begin{array}{l}{ }^{31} \mathrm{P} \mathrm{NMR} \\
{[\mathrm{ppm}]^{\mathrm{a}}}\end{array}$} & \multirow{2}{*}{$\begin{array}{l}\text { Yield } \\
{[\%]}\end{array}$} & \multirow{2}{*}{$\begin{array}{l}\text { m.p. } \\
{\left[{ }^{\circ} \mathrm{C}\right]}\end{array}$} & \multicolumn{2}{|c|}{${ }^{31} \mathrm{P}$ NMR } & \\
\hline & & & & & & $2 \mathrm{M} \mathrm{HCl}$ & $2 \mathrm{M} \mathrm{NaOH}$ & \\
\hline $\mathrm{Asp}^{\mathrm{P}, \mathrm{P}}$ & 75 & $\begin{array}{l}150- \\
151\end{array}$ & $\begin{array}{l}15.6 ; \\
16.3 ; \\
26.0 ; 26.7\end{array}$ & 70 & $233-235$ & $\begin{array}{l}13.6 ; 14.3 ; \\
22.9 ; 23.6\end{array}$ & $\begin{array}{l}22.07 ; \\
22.12\end{array}$ & 71 \\
\hline & & & & & 233-235 & & & 72 \\
\hline $\mathrm{Glu}^{\mathrm{P}, \mathrm{P}}$ & 70 & $\begin{array}{l}145- \\
147\end{array}$ & $\begin{array}{l}17.3 ; 17.4 \\
31.2 ; 31.4\end{array}$ & 65 & $\begin{array}{l}234-236 \\
236-238\end{array}$ & $15.0 ; 19.6$ & $\begin{array}{l}21.9 ; 22.0 \\
23.3 ; 23.4\end{array}$ & 71 \\
\hline & & & & & $237-239$ & & & 72 \\
\hline $\mathrm{HGlu}^{\mathrm{P}, \mathrm{P}}$ & 58 & oil & $18.3 ; 32.4$ & 50 & $235-237$ & $15.9 ; 29.0$ & $13.6 ; 25.6$ & 71 \\
\hline $\mathrm{HGlu}^{\gamma-\mathrm{P}}$ & 73 & oil & $16.6^{\mathrm{b}}$ & 70 & $158-159$ & 15.8 & 21.8 & 74 \\
\hline
\end{tabular}

Synthesis of 1-aminoalkyl-1,n-diphosphonic acids $\underline{3}(\mathrm{n}=1,2,3)$. General procedure $\mathrm{A}$ [Kudzin et al., J. Organometal. Chem. 1994 ${ }^{71}$ ]

Triphenyl phosphite $(0.015 \mathrm{~mol} ; 4.65 \mathrm{~g})$ was added in one portion to a solution of aldehyde $\underline{\mathbf{1}}$ $(0.01 \mathrm{~mol})$ and $\mathrm{N}$-phenylthiourea $(0.015 \mathrm{~mol} ; 2.26 \mathrm{~g})$ in glacial acetic acid $(20 \mathrm{ml})$. The mixture was stirred at $60^{\circ} \mathrm{C}$ for $1 \mathrm{~h}$, left to stand overnight at room temperature and then diluted with water $(2 \mathrm{ml})$. After $6 \mathrm{~h}$ the precipitate was filtered off and washed with $\mathrm{AcOH} / \mathrm{H}_{2} \mathrm{O}(1: 1)$ to give corresponding thioureidoalkylphosphonate Ptc- $\mathrm{AA}^{\mathrm{P}, \mathrm{P}}(\mathrm{OPh})_{2}(\mathrm{n}=1,2)$ as crystalline compounds pure as indicated by their ${ }^{31} \mathrm{P}$ NMR spectra. The products were purified for microanalysis by recrystallization from chloroform-methanol (5:1). Thioureidoalkylphosphonate Ptc$\mathrm{HGlu}^{\mathrm{P}, \mathrm{P}}(\mathrm{OPh})_{2}(\mathrm{n}=3)$ was isolated as an oil by chromatography on a silica column [eluent: chloroform-methanol (10:1)]. Thioureidoalkylphosphonates Ptc- $\mathrm{AA}^{\mathrm{PP}}(\mathrm{OPh})_{2}$ were dissolved in glacial acetic acid $(50 \mathrm{ml})$ and hydrochloric acid $(100 \mathrm{ml}, 1: 1)$ and the solution was heated under reflux for $12 \mathrm{~h}$. The mixture was then cooled to room temperature, diluted with water (100 $\mathrm{ml})$, and extracted with toluene $(2 \times 50 \mathrm{ml})$. The aqueous layer was evaporated to dryness under reduced pressure, and the solid residue was dissolved in water $(10 \mathrm{ml})$. The solution was passed through Dowex $50 \mathrm{~W} \times 8$ column and fractions containing amino acids $\mathrm{AA}^{\mathrm{pp}}$ (ninhydrin test) were collected. The combined fractions containing AAP,P, respectively, were concentrated under reduced pressure to ca. $5 \mathrm{ml}$ and 1-aminoalkyldiphosphonic acids were precipitated with ethanol $(25 \mathrm{ml})$, and dried to constant weight in a dessicator under reduced pressure over solid phosphorus pentoxide and potassium hydroxide.

2.2.3. Synthesis of $\omega$-nitro-1-aminoalkylphosphonic acids. The biological activity of Fosmidomycin (Fr 31546) induced our interest in the preparation of its amino analogs. ${ }^{75}$ We have 
found that the reaction of 3-nitropropanal and 4-nitrobutanal (precursors of analogs of Fr 31546) with Ptc- $\mathrm{NH}_{2}$ and triphenyl phosphite occurs in different modes, dependent on the structure of applied $\omega$-nitroalkanal (Scheme 16).

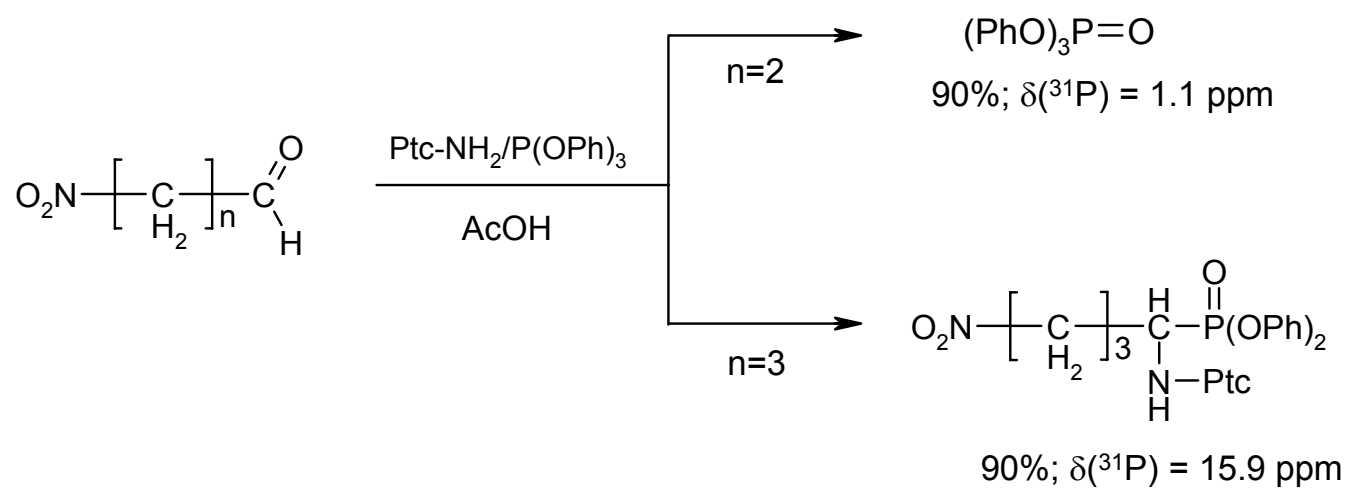

\section{Scheme 16}

Starting from 4-nitroalkanals $\underline{\mathbf{1}}$, easily prepared from acrolein and the corresponding nitroalkanes, the representative Ptc-1-amino-4-nitroalkylphosphonates [Ptc-NAA ${ }^{\mathrm{P}}(\mathrm{OPh})_{2}$ ] were obtained in good to high yields (Table 9). However, their subsequent acidic hydrolysis afforded products of structure dependent on the structure of the starting $\operatorname{Ptc}^{-N A A}{ }^{\mathrm{P}}(\mathrm{OPh})_{2}$.

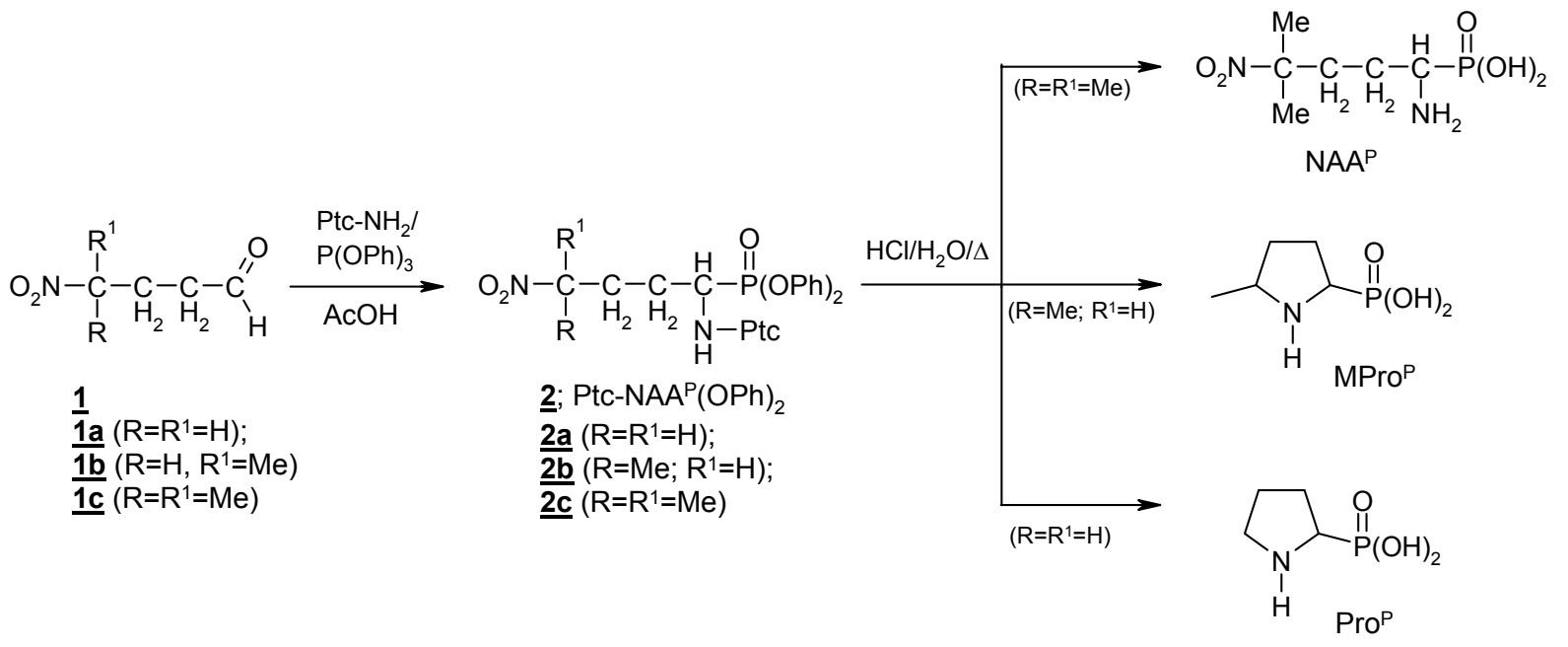

\section{Scheme 17}

Thus, the degradation of diphenyl 1-Ptc-amino-4-methyl-4-nitropentylphosphonate [1-(Nphenylthioureido)-4-methyl-4-nitropentylphosphonate] afforded 1-amino-4-nitro-4-methylpentylphosphonic acids $\left[\underline{\mathbf{2}} \rightarrow \mathrm{NAA}^{\mathrm{P}}\right]$ whereas degradation of diphenyl 1-Ptc-amino-4-nitropentylphosphonate [1-(N-phenylthioureido)-4-nitropentylphosphonate $](\underline{\mathbf{2 b}})$ occurred with intermolecular rearrangement giving 4-methylpyrrolidinephosphonic acid (MPro ${ }^{\mathrm{P}}$ ). Similarly, 
degradation of diphenyl 1-Ptc-amino-4-nitrobutylphosphonate [1-(N-phenylthioureido)-4nitrobutylphosphonate] (르) afforded 2-pyrrolidinephosphonic acid (Pro ${ }^{\mathrm{P}}$ ) (Scheme 17, Table 9) (the details on these rearrangements will be published in a separate paper $^{76}$ ).

Table 9. Ptc-amino-4-nitroalkylphosphonates and products of their degradation

\begin{tabular}{|c|c|c|c|c|c|c|c|c|c|}
\hline \multirow[t]{3}{*}{$\mathrm{R}, \mathrm{R}^{1}$} & \multicolumn{4}{|c|}{ 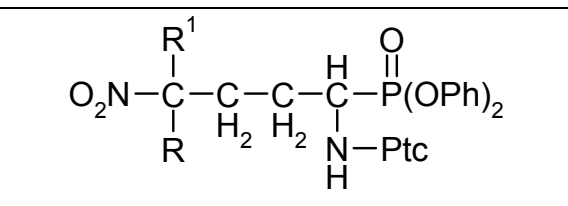 } & \multicolumn{5}{|c|}{ 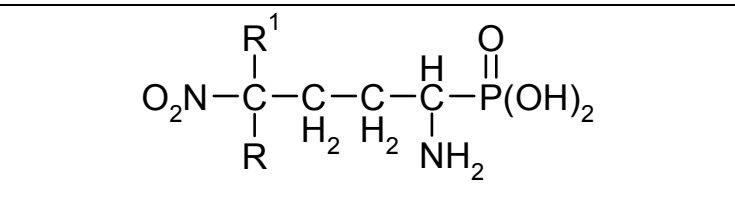 } \\
\hline & \multirow[t]{2}{*}{$\begin{array}{l}\text { Yield } \\
{[\%]}\end{array}$} & \multirow[t]{2}{*}{$\begin{array}{l}\text { m.p. } \\
{\left[{ }^{\circ} \mathrm{C}\right]}\end{array}$} & \multicolumn{2}{|c|}{$\begin{array}{c}{ }^{31} \mathrm{P} \text { NMR } \\
{[\mathrm{ppm}]^{\mathrm{a}}}\end{array}$} & \multirow[t]{2}{*}{$\begin{array}{l}\text { Yield } \\
{[\%]}\end{array}$} & \multirow[t]{2}{*}{$\begin{array}{l}\text { m.p. } \\
{\left[{ }^{\circ} \mathrm{C}\right]}\end{array}$} & \multicolumn{3}{|c|}{${ }^{31} \mathrm{P}$ NMR } \\
\hline & & & $\mathrm{AcOH}$ & $\mathrm{CDCl}_{3}$ & & & $\begin{array}{l}\mathrm{TFA}^{\mathrm{a}} / \\
\mathrm{HCl}^{\mathrm{b}}\end{array}$ & $\mathrm{H}_{2} \mathrm{O}$ & $\begin{array}{l}2 \mathrm{M} \\
\mathrm{NaOH}\end{array}$ \\
\hline $\mathrm{R}=\mathrm{R}^{1}=\mathrm{H}$ & 70 & $145-150$ & & 17.7 & - & glass & $17.5^{\mathrm{a}}$ & $12.3^{\mathrm{c}}$ & 20.9 \\
\hline $\mathrm{R}=\mathrm{H} ; \mathrm{R}^{1}=\mathrm{Me}$ & 70 & $145-152$ & & 17.8 & - & glass & & $13.8^{\mathrm{d}}$ & 18.7 \\
\hline $\mathrm{R}=\mathrm{R}^{1}=\mathrm{Me}$ & 80 & $135-145$ & 15.9 & 16.5 & 80 & $\begin{array}{c}>250^{\circ} \mathrm{C} \\
(\text { dec. })\end{array}$ & $15.2^{\mathrm{b}}$ & $12.3^{\mathrm{d}}$ & 20.8 \\
\hline
\end{tabular}

${ }^{31}$ P NMR: ${ }^{\mathrm{a}} \mathrm{TFA} ;{ }^{\mathrm{b}} 2 \mathrm{M} \mathrm{HCl} ;{ }^{\mathrm{c}} 2 \mathrm{M}$ AcOH$/ \mathrm{AcONa}-\mathrm{D}_{2} \mathrm{O} ;{ }^{\mathrm{c}} \mathrm{EtOH}-\mathrm{D}_{2} \mathrm{O}(1: 1)$.

2.2.4. Application of the Ptc-aminophosphonate and related protocols for the synthesis of optical pure 1-aminoalkylphosphonic acids. The Ptc-aminophosphonate method was adapted for the preparation of both levorotatory and dextrorotatory 1-aminoalkylphosphonic acids via the hydrolysis of the corresponding intermediary $N^{\prime}$-1-methylbenzylaminoureidophosphonates (Scheme 18). ${ }^{77,78}$

In a similar approach, applied for both levorotatory and dextrorotatory $N$-(1-methylbenzyl)thioureas $\left[(R)-\mathrm{Bmtc}-\mathrm{NH}_{2}\right.$ and $\left.(S)-\mathrm{Bmtc}-\mathrm{NH}_{2}\right]$, temporary Bmtc-Ala ${ }^{\mathrm{P}}(\mathrm{OPh})_{2}$ obtained, as well as the product of their final acidic hydrolysis - phosphonoalanine $\left(\mathrm{Ala}^{\mathrm{P}}\right)$ did not exhibit remarkable optical activity ${ }^{29}$ (Scheme 18).

Results of the reaction of benzylacetaldehyde, with $\mathrm{N}$-phenylthiourea and triphenyl phosphite in acetic acid containing 10\% of chiral Bronsted acids are summarized in Table 10. 


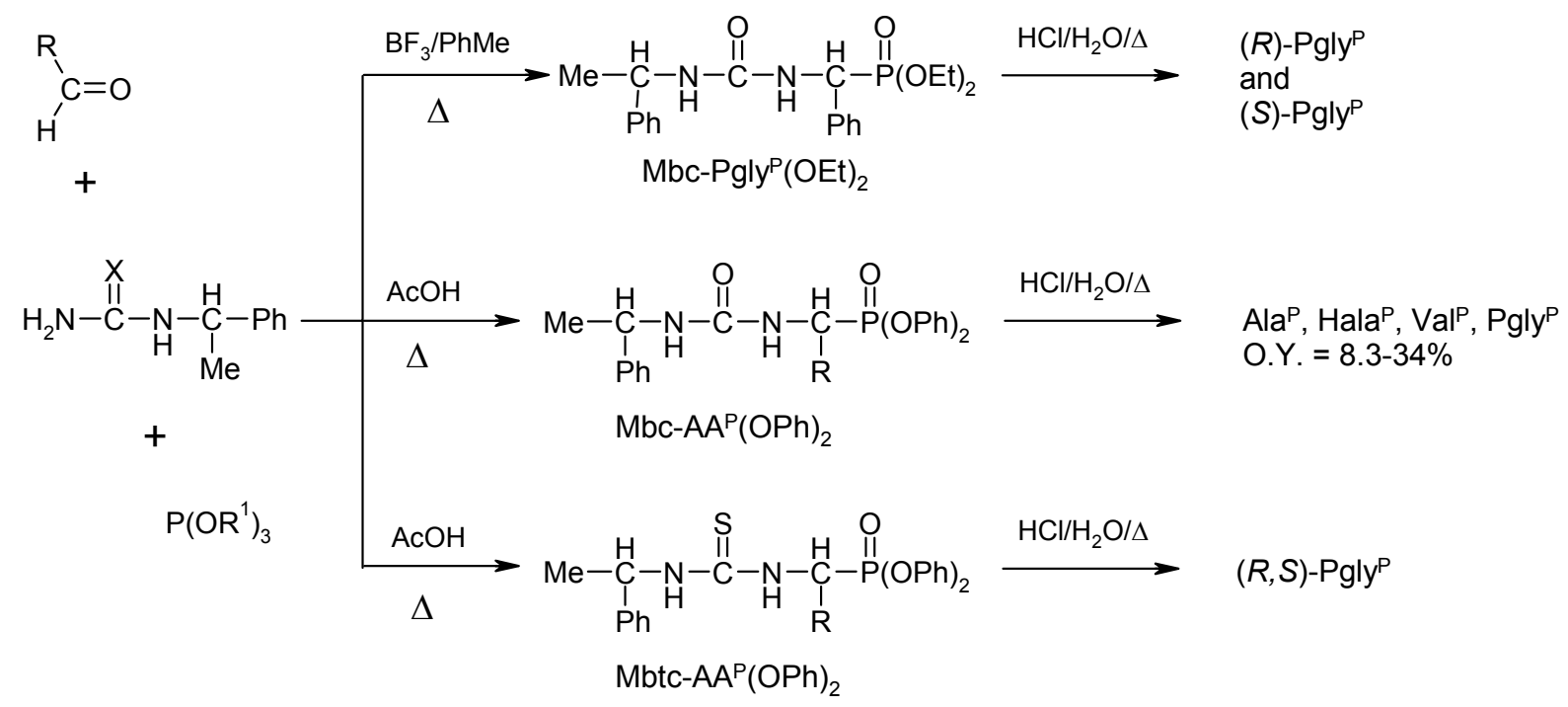

\section{Scheme 18}

Table 10. The partial ${ }^{31} \mathrm{P}$ NMR spectra of reaction mixture of synthesis of $\mathrm{Ptc}-\mathrm{Phe} \mathrm{P}^{\mathrm{P}}(\mathrm{OPh})_{2}$ in acetic acid-chiral Bronsted acids (CHBA)

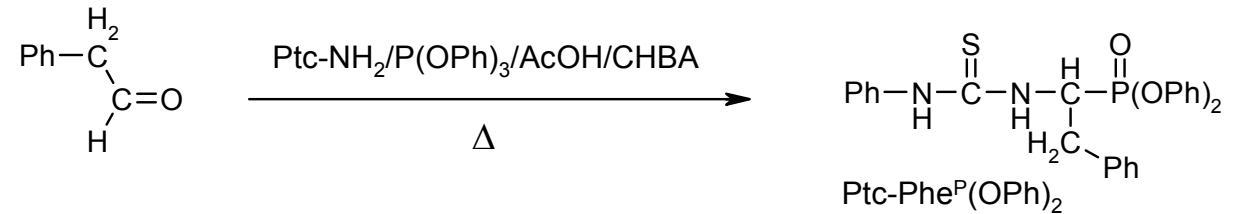

\begin{tabular}{|c|c|c|c|c|c|c|c|c|c|}
\hline \multicolumn{10}{|c|}{$\operatorname{AcOH} /(2 R, 3 R)-(+)$-tartaric acid $(10 \%)$} \\
\hline \multirow[t]{2}{*}{${ }^{31} \mathbf{P}(\delta)$} & [ppm] & 37 & 35.4 & 17.4 & 16.2 & 15. & 1.3 & & -18.7 \\
\hline & {$[\%]$} & 8.5 & 1.5 & 5 & 28 & 16 & 24 & & 2 \\
\hline \multicolumn{10}{|c|}{ AcOH/(+)-2,3-dibenzoyl-D-tartaric acid (10\%) } \\
\hline \multirow[t]{2}{*}{${ }^{31} \mathbf{P}(\delta)$} & [ppm] & 37 & 33.4 & 33.5 & 17.2 & 16.3 & 6.6 & 2.8 & -18.7 \\
\hline & {$[\%]$} & 8.5 & 1.5 & 5 & 5 & 28 & 16 & 24 & 2 \\
\hline \multicolumn{10}{|c|}{ AcOH/(1S)-(+)-camphorsulfonic acid (10\%) } \\
\hline \multirow[t]{2}{*}{${ }^{31} \mathbf{P}(\delta)$} & [ppm] & 38.3 & 36.1 & 33.7 & 19.7 & 16.4 & 4.1 & 1.4 & -18.7 \\
\hline & {$[\%]$} & & 10 & 6 & 7 & 10 & 40 & 10 & 4 \\
\hline
\end{tabular}

${ }^{\mathrm{a}} \delta\left({ }^{31} \mathrm{P}\right):(\mathrm{PhO})_{3} \mathrm{P} 127 \pm 1 \mathrm{ppm} ;(\mathrm{PhO})_{2} \mathrm{P}(\mathrm{O}) \mathrm{H} 0 \pm 0.5$ ppm; $(\mathrm{PhO}) \mathrm{P}(\mathrm{O})(\mathrm{OH})_{2}-4.7 \mathrm{ppm} ;(\mathrm{PhO}){ }_{3} \mathrm{P}(\mathrm{O})$ $17.5 \pm 1 \mathrm{ppm}^{79}$

These results show that this approach for the preparation of optically active 1-aminoalkylphosphonic acids cannot be considered as an effective one.

2.2.5. Application of the Ptc-aminophosphonate and related methods for synthesis of diphenyl 1-aminoalkylphosphonates. Diphenyl Z-aminoalkylphosphonates - are applied as the 
substrates in preparation of diphenyl 1-aminoalkylphosphonates and subsequently for $P$-terminal phosphono-peptides synthesis. ${ }^{24,80-91}$

Since intermediary structures, $\mathrm{Z}-\mathrm{AA}^{\mathrm{P}}(\mathrm{OPh})_{2}$, could be isolated from the reaction mixtures in moderate yields [e.g. Z-Gly ${ }^{\mathrm{P}}(\mathrm{OPh})_{2} \quad(45-56 \%) ; \mathrm{Z}-\mathrm{Ala}^{\mathrm{P}}(\mathrm{OPh})_{2} \quad(42 \%) ; \mathrm{Z}-\mathrm{Val}^{\mathrm{P}}(\mathrm{OPh})_{2} \quad(50 \%) ; \mathrm{Z}-$ $\operatorname{Leul}^{\mathrm{P}}(\mathrm{OPh})_{2}(51 \%)$; Z-Pgl ${ }^{\mathrm{P}}(\mathrm{OPh})_{2}(50 \%)$ or $\left.\mathrm{Z}-\mathrm{Phe} \mathrm{P}^{\mathrm{P}}(\mathrm{OPh})_{2}(32 \%)\right]^{24,80}$ we undertook investigations on the further modification of the thioureido-moiety of easily isolable Atc- $A A^{\mathrm{P}}(\mathrm{OPh})_{2}$. We applied

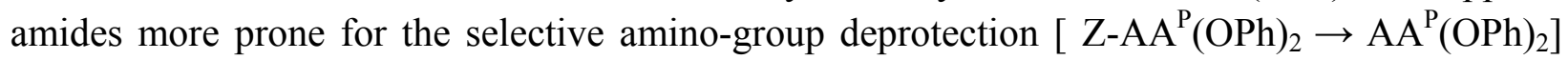
derivatives (Scheme 19).

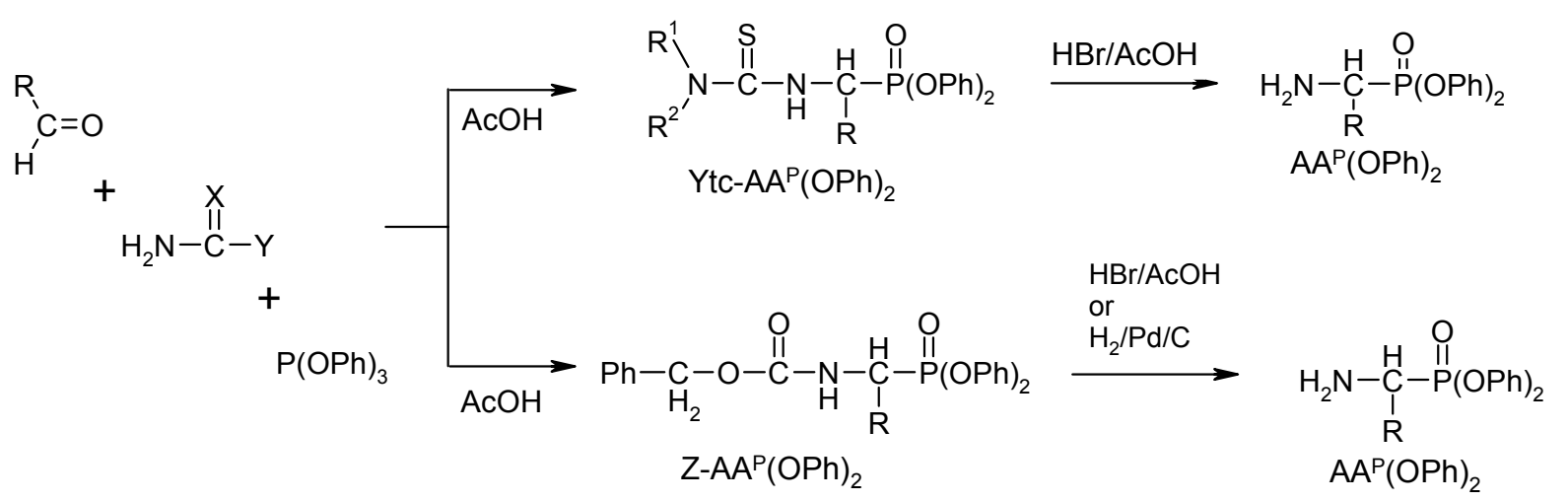

\section{Scheme 19}

The types of starting amides and structures of the corresponding diphenyl 1amidoalkylphosphonates are summarized in Table 11.

Table 11. Amides and the corresponding diphenyl 1-amidoalkylphosphonates

\begin{tabular}{|c|c|c|}
\hline Starting amides & Expected product & $\begin{array}{c}{ }^{31} \mathrm{P} \text { NMR } \\
\delta\left({ }^{31} \mathrm{P}\right) \text { vs RA [\%] }\end{array}$ \\
\hline$\prod_{-\mathrm{C}}^{\mathrm{S}}-\mathrm{NH}_{2}$ & 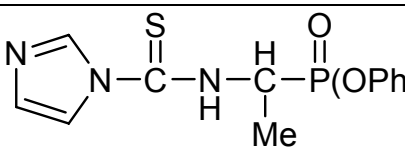 & Broad signal $19 \pm 4 \mathrm{ppm}$ \\
\hline 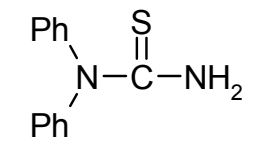 & 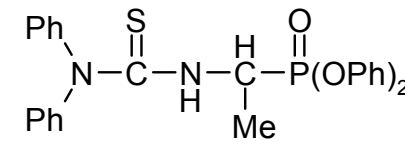 & $\begin{array}{cc}21.2 & 20 \\
(20 \%) & (40 \%)\end{array}$ \\
\hline $\mathrm{Ph}_{\substack{\mathrm{P} \\
\mathrm{Ph}}}^{\mathrm{O}}-\mathrm{NH}_{2}$ & 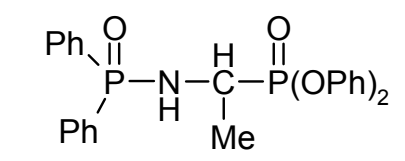 & $\begin{array}{c}29.4 ; 28.3(33 \%) ; \\
19.2 ; 18.7(20 \%)\end{array}$ \\
\hline
\end{tabular}


Table 11. Continued

\begin{tabular}{|c|c|c|c|c|}
\hline 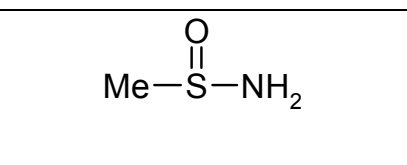 & 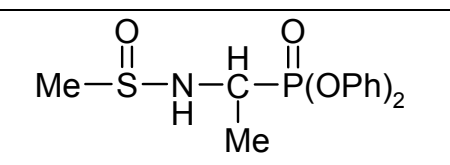 & $\begin{array}{c}20.0 \\
(20 \%)\end{array}$ & $\begin{array}{c}17.7 \\
(40 \%)\end{array}$ & \\
\hline$\stackrel{\stackrel{S}{\|}}{\mathrm{C}}-\mathrm{O}-\mathrm{NH}_{2}$ & 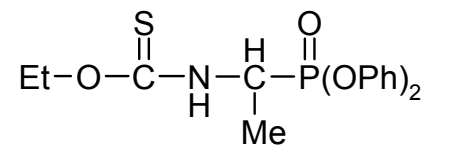 & $\begin{array}{c}18.8 \\
(40 \%)\end{array}$ & $\begin{array}{c}17.5 \\
(18 \%)\end{array}$ & $\begin{array}{c}16.0 \\
(10 \%)\end{array}$ \\
\hline$\stackrel{\stackrel{S}{I I}}{\mathrm{C}}-\mathrm{NH}_{2}$ & $\begin{array}{c}\mathrm{S} \\
\mathrm{Et}-\mathrm{S}-\mathrm{C}-\mathrm{N}-\stackrel{\mathrm{H}}{\mathrm{C}}-\stackrel{\mathrm{O}}{\mathrm{C}}-\mathrm{P}(\mathrm{OPh})_{2} \\
\mathrm{Me}\end{array}$ & $\begin{array}{c}18.9 \\
(42 \%)\end{array}$ & $\begin{array}{c}16.7 \\
(25 \%)\end{array}$ & \\
\hline $\mathrm{H}_{2} \mathrm{~N}-\stackrel{\mathrm{S}}{\mathrm{C}}-\mathrm{S}-\mathrm{S}-\stackrel{\mathrm{S}}{\mathrm{C}}-\mathrm{NH}_{2}$ & 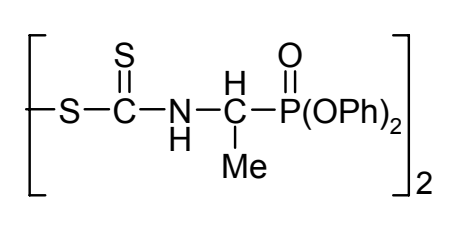 & \multicolumn{3}{|c|}{ Multicomponent mixture } \\
\hline $\mathrm{N} \equiv \mathrm{C}-\mathrm{NH}_{2}$ & $\begin{array}{c}\mathrm{O} \\
\mathrm{N} \equiv \mathrm{C}-\mathrm{N}-\mathrm{N}-\mathrm{C} \\
\mathrm{H}-\mathrm{P}(\mathrm{OPh})_{2} \\
\mathrm{Me}\end{array}$ & $\begin{array}{c}19.3 \\
(45 \%)\end{array}$ & $\begin{array}{c}16.3 \\
(46 \%)\end{array}$ & \\
\hline
\end{tabular}

The low degree of the conversions of listed amides into the corresponding 1amidoalkylphosphonates (Table 10), as well as, problems from their isolation from the reaction mixtures, in the light of recent reports on almost quantitative synthesis of $\mathrm{Z}-\mathrm{AA}^{\mathrm{P}}(\mathrm{OPh})_{2}{ }^{92,93}$ made the continuation of this approach for the synthesis of these precursors of $\mathrm{AA}^{\mathrm{P}}(\mathrm{OPh})_{2}$ not reasonable.

\section{Other modifications}

\subsection{Z-Aminophosphonate Method (Birum-Oleksyszyn Method)}

Modifications of the Birum reaction by the use of easily degradable benzyl carbamate10-12,25,30 present the base of the Z-aminophosphonate method (Birum-Oleksyszyn Method) (C), ${ }^{23-25,46,80-}$ 91,93-96 (Scheme 3), allowing the synthesis of structurally diverse $\mathrm{AA}^{\mathrm{P}}$ and also their diester derivatives $\mathrm{AA}^{\mathrm{P}}(\mathrm{OPh})_{2}$. The yields of the Oleksyszyn and Tyka protocol are greatly improved when reactions are carried out in the presence of Lewis acids. ${ }^{92,93}$

In other modifications $N$-phenylurea ${ }^{22}$ optically active $N$-(1-methylbenzyl)ureas ${ }^{77,78}$ and carbamates, ${ }^{78} \mathrm{O}, O$-diethyl phosphoramidothioate, ${ }^{97,98}$ or $O$-ethyl, $O$-phenyl phosphoramidothioate, ${ }^{97} \mathrm{O}, \mathrm{O}$-dipropyl phosphoroamidate, ${ }^{99} \mathrm{~N}$-acyl-4-aminobutanal, ${ }^{100}$ 2-amino-5-phenyl-1,3,4oxadiazole or 1,3,4-thiadiazole ${ }^{101}$ have also been applied. 


\subsection{Oleksyszyn Method}

The first essential modification of the Engelman and Pikl reaction, reported by Oleksyszyn, Tyka and Mastalerz in $1978,{ }^{28,25}$ was based on the replacement of $N$-(hydroxymethyl)amides by hydroxyamides, prepared in situ from carbamates and carbonyl compounds (Scheme 20; Y=OBn).

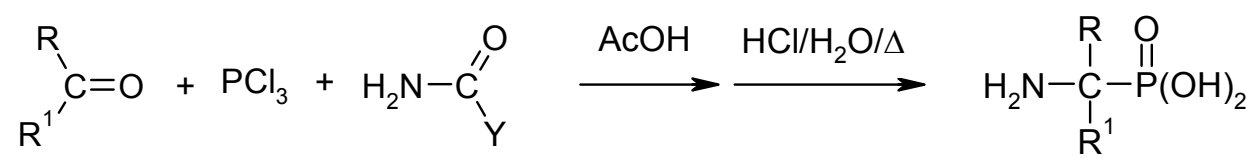

R, R1 = H, H; H, alkyl; H, aryl; alkyl, alkyl; cycloalkyl; alkyl, aryl; $Y=H$, alkyl, aryl, BnO

\section{Scheme 20}

This procedure was subsequently modified by Oleksyszyn ${ }^{28,102-106}$ and other members of the Wroclaw Amino Acid School ${ }^{46,48,96,107-113}$ becoming one of the most commonly used for the preparation of structurally diverse aminophosphonates. ${ }^{10,12}$

These modifications applied the use of carbamates and/or various amides, ${ }^{44,48,104,105,107,110-121,122-}$ 124 bisamides $^{105,109,119}$ or formed in situ 1-(acylamino)alkyl alkanoates, ${ }^{48} p$-toluenesulfonamide, ${ }^{125,126,127} O, O$-diethyl phosphoramidothioate, ${ }^{115}$ or $O$-ethyl, $O$-phenyl ${ }^{115}$ diethyl phosphoramidate or phosphorthioamidate, ${ }^{115}$ 1,3-oxazolidin-2-one ${ }^{128}$ and 5,5-dimethylhydantoin. ${ }^{129,130}$

In others, phosphorus trichloride was replaced by various chlorophosphites, ${ }^{115,125,127,131-133}$ dichlorophosphites, ${ }^{123,131,132,134,135}$ dithioisopropyl-chlorophosphites ${ }^{131}$ and $\mathrm{PhOPCl}_{2} / \mathrm{AcCl}$ mixture. ${ }^{136}$ Also two- and tricomponent mixtures of dialkyl phosphites were applied, including $(\mathrm{RO})_{2} \mathrm{P}(\mathrm{O}) \mathrm{H} / \mathrm{AcCl},{ }^{105,120,137,138}(\mathrm{PhO})_{2} \mathrm{P}(\mathrm{O}) \mathrm{H} / \mathrm{AcCl},{ }^{126}(\mathrm{RO})_{2} \mathrm{P}(\mathrm{O}) \mathrm{H} / \mathrm{AcOH} / \mathrm{SO}_{2} \mathrm{Cl}_{2}{ }^{137,139}$ and also (RO) ${ }_{2} \mathrm{P}(\mathrm{O}) \mathrm{H} / \mathrm{Ac}_{2} \mathrm{O} / \mathrm{HCl}$ mixtures, ${ }^{139}$ as well as $\mathrm{PCl}_{3} / \mathrm{P}(\mathrm{OMe})_{3}{ }^{140,141}$ and $\mathrm{PCl}_{3} / \mathrm{AcOH} / \mathrm{SO}_{2} \mathrm{Cl}_{2}{ }^{117}$ mixtures. Amidoalkylation of phosphorous acid $25,105,106,109$ and alkylphosphonic acids in $\mathrm{RP}(\mathrm{O})(\mathrm{OH})_{2} / \mathrm{Ac}_{2} \mathrm{O}$ mixtures $(\mathrm{R}=\mathrm{Me}, \mathrm{Ph}){ }^{105}$ were also applied.

The application of dichloroalkylphosphines and/or dichloroarylphosphines, ${ }^{28,102-104,112-114,}$, 142,143 a functionalized or nonfunctionalized phosphonites ${ }^{144,145}$ and hypophosphorous acid ${ }^{111}$ (for the preparation of 1-aminoalkylphosphinic acids), or chlorodialkylphosphines ${ }^{105,116}$ allowed on the preparation of 1-aminoalkylphosphinic acids and/or 1-aminoalkanephosphine oxides, respectively.

The mechanisms of the Engelman-Pikl-Oleksyszyn reaction have been in detail examined by Oleksyszyn ${ }^{25,105}$ and Soroka. ${ }^{48,107,109}$ Recently discussion on the mechanism of amidoalkylation of hydrophosphoryl compounds was also presented by Dmitriev and Ragulin. ${ }^{146}$

\subsection{Synthesis of 1- $N$-alkyl(aryl)aminoalkylphosphonates}

The Birum-type condensations of carbonyl compounds, trialkyl phosphites and amines, hydrazines or hydroxylamines affords the corresponding 1- $N$-alkyl(aryl)aminoalkyl- 
phosphonates, substituted hydrazinealkyl- and/or hydroxylalkylphosphonates, respectively (Scheme 21).
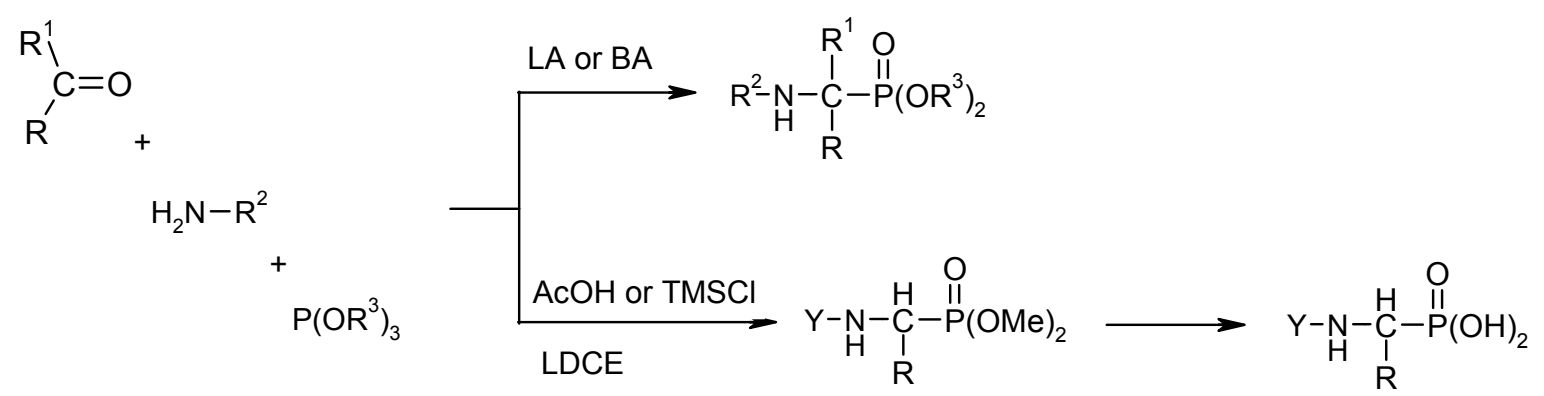

$\mathrm{R}, \mathrm{R}^{1}=\mathrm{H}$, alkyl; H, aryl; $\mathrm{H}$, aralkyl; $\mathrm{R}^{2}=$ alkyl, aryl; $\mathrm{R}^{3}=\mathrm{Me}, \mathrm{Et} ; \mathrm{Y}=\mathrm{Me}_{2} \mathrm{~N}, \mathrm{PhO}$

\section{Scheme 21}

The reported modifications of this procedure are based on the use of LPDE catalysis, ${ }^{147-149}$ the use of Bronsted acids \{BA: sulfonic acid functionalized ionic liquid, ${ }^{150}$ silica-sulfuric acid, ${ }^{151}$ oxalic acid ${ }^{152}$ and/or boric acid ${ }^{153}$ or Lewis acids [LA: CAN, ${ }^{154} \mathrm{VCl}_{3},{ }^{155} \mathrm{TiCl}_{4},{ }^{156} \mathrm{Cu}(\mathrm{OTf})_{2},{ }^{157}$ $\mathrm{AlCl}_{3}{ }^{158}$ or Sc tris(dodecyl sulfate), ${ }^{159}$ or a realization of tri-component condensation under solvent-free conditions using $\mathrm{Al}\left(\mathrm{H}_{2} \mathrm{PO}_{4}\right)_{3}$ as an efficient and reusable heterogeneous catalyst ${ }^{160}$ or without catalyst. ${ }^{161}$

\section{Nomenclature and applied abreviations code}

The compounds discussed are listed in Table 12 together with the code used to identified them latter in tables and schemes. This sytem of abbreviations used for assingement of aminoalkylphosphonic acids and derivatives has already been applied in the fragmentary form in our earlier papers ${ }^{13-15}$ and its full version will be published elsewhere.

Table 12. Codes used for the representative phosphonic acid and derivatives ${ }^{13-15}$

\begin{tabular}{|c|c|}
\hline Code & Compound name \\
\hline $\mathrm{AA}^{\mathrm{P}} \mathrm{s}$ & 1-Aminoalkylphosphonic Acids ${ }^{13}$ \\
\hline $\mathrm{AA}^{\mathrm{P}}(\mathrm{OR})_{2}$ & Dialkyl 1-Aminoalkylphosphonate; Dialkyl Phosphono-Amino-Acidate ${ }^{a}$ \\
\hline $\operatorname{Gly}^{\mathrm{P}}(\mathrm{OMe})_{2}$ & Dimethyl 1-Aminomethylphosphonate; Dimethyl Phosphonoglycinate ${ }^{a}$ \\
\hline$(\mathrm{AC})-\mathrm{AA}^{\mathrm{P}}$ & 1-(N-Acylamino)alkylphosphonic Acid ${ }^{13} ;\left(\right.$ ACyl)-PhosphonoAmino Acid ${ }^{\mathrm{a}}$ \\
\hline Ac-AA ${ }^{P}$ & 1-(N-Acetylamino)alkylphosphonic Acid $^{13}$ \\
\hline Ac-Ala ${ }^{\mathrm{P}}$ & Acetyl-phosphonoalanine ${ }^{\mathrm{a}} ; 1-(N$-Acetylamino)ethylphosphonic Acid \\
\hline $\mathrm{Bz}-\mathrm{AA}^{\mathrm{P}}$ & 1-(N-Benzoylamino)alkylphosphonic Acid ${ }^{13}$ \\
\hline TFA-AA ${ }^{P}$ & 1-(N-Trifluoroacetylamino)alkylphosphonic Acid $^{14}$ \\
\hline
\end{tabular}


Table 12. Continued

\begin{tabular}{|c|c|}
\hline Mca-AA $^{\mathrm{P}}$ & 1-(N-Chloroacetylamino)alkylphosphonic Acid $^{15}$ \\
\hline \multirow[t]{2}{*}{$(\mathrm{Ac})-\mathrm{AA}^{\mathrm{P}}(\mathrm{OR})_{2}$} & Dialkyl Acetylphosphono-Amino Acidate ${ }^{a}$ \\
\hline & Dialkyl 1-(N-Acetylamino)alkylphosphonate ${ }^{13}$ \\
\hline \multirow[t]{2}{*}{ 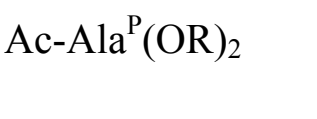 } & Dialkyl Acetylphosphonoalaninate \\
\hline & Dialkyl 1-(N-Acetylamino)ethylphosphonate ${ }^{13}$ \\
\hline PTC-AAs & 1-(Phenylthiocarbamoyl)-Amino Acids ${ }^{162,163}$ \\
\hline Ptc-AA ${ }^{\mathrm{P}}$ & 1-(Phenylthiocarbamoylamino)alkylphosphonic Acids ${ }^{\mathrm{a}}$ \\
\hline Ptc-AA ${ }^{\mathrm{P}}(\mathrm{OR})_{2}$ & Dialkyl 1-(Phenylthiocarbamoylamino)alkylphosphonate ${ }^{\mathrm{a}}$; \\
\hline \multirow[t]{2}{*}{ Ptc-AA ${ }^{\mathrm{P}}(\mathrm{OAr})_{2}$} & Diaryl 1-(Phenylthiocarbamoylamino)alkylphosphonate ${ }^{\mathrm{a}}$; \\
\hline & Diaryl 1-(3-Phenylthioureido)alkylphosphonate ${ }^{55,56}$ \\
\hline \multirow[t]{2}{*}{ Ptc-AA ${ }^{\mathrm{P}}(\mathrm{OPh})_{2}$} & Diphenyl 1-(Phenylthiocarbamoylamino)alkylphosphonate ${ }^{\mathrm{a}}$; \\
\hline & Diphenyl 1-( $N$-Phenylthioureido)alkylphosphonate ${ }^{39,41,55,56}$ \\
\hline \multirow[t]{2}{*}{ Ptc-Ala ${ }^{\mathrm{P}}(\mathrm{OPh})_{2}$} & Diphenyl Phenylthiocarbamoyl-phosphonoalaninate ${ }^{\mathrm{a}}$; \\
\hline & Diphenyl 1-(3-Phenylthioureido)ethylphosphonate ${ }^{38}$ \\
\hline \multirow[t]{2}{*}{ Ptc-Hala ${ }^{\mathrm{P}}(\mathrm{OPh})_{2}$} & Diphenyl Phenylthiocarbamoyl-phosphonohomoalaninate ${ }^{\mathrm{a}}$; \\
\hline & $O, O$-Diphenyl 1-(3-phenylthioureido)butanephosphonate ${ }^{40}$ \\
\hline \multirow[t]{2}{*}{ Ptc-tLeu ${ }^{\mathrm{P}}(\mathrm{OPh})_{2}$} & Diphenyl Phenylthiocarbamoyl-phosphonotertleucinate; \\
\hline & $O, O$-Diphenyl 2-methyl-1-(3-phenylthioureido)propanephosphonate ${ }^{37}$ \\
\hline \multirow[t]{2}{*}{ Ptc-Nleu ${ }^{\mathrm{P}}(\mathrm{OPh})_{2}$} & Diphenyl Phenylthiocarbamoyl-phosphononorleucinate \\
\hline & $O, O$-diphenyl 1-(3-phenylthioureido)-pentanephosphonate ${ }^{40}$ \\
\hline Pc-AA ${ }^{P}$ & 1-(Phenylcarbamoylamino)alkylphosphonic Acid A $^{\mathrm{a}}$ \\
\hline $\mathrm{Pc}-\mathrm{AA}^{\mathrm{P}}(\mathrm{OAr})_{2}$ & Diaryl 1-(Phenylcarbamoylamino)alkylphosphonate ${ }^{a}$ \\
\hline \multirow[t]{2}{*}{ Pc-Pgly ${ }^{\mathrm{P}}(\mathrm{OEt})_{2}$} & Diethyl Phenylcarbamoyl-phosphonophenylglycinate ${ }^{a}$ \\
\hline & Diethyl 1-(3-Phenylureido)ethylphosphonate ${ }^{16}$ \\
\hline $\mathrm{Ac}^{*}-\mathrm{AA}^{\mathrm{P}}(\mathrm{OPh})_{2}$ & 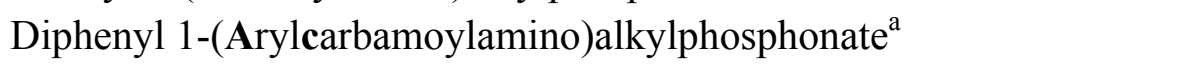 \\
\hline $\operatorname{Dpc}-\mathrm{Ala}^{\mathrm{P}}(\mathrm{OPh})_{2}$ & Diphenyl Diphenylcarbamoyl-phosphonoalaninate ${ }^{a}$; \\
\hline Atc-AA ${ }^{P}$ & 1-(Arylthiocarbamoylamino)alkylphosphonic Acid ${ }^{\mathrm{a}}$; \\
\hline \multirow[t]{2}{*}{$\mathrm{Tc}-\mathrm{AA}^{\mathrm{P}}$} & 1-(Thiocarbamoylamino)alkylphosphonic Acid A $^{\mathrm{a}}$ \\
\hline & 1-(Thioureido)alkylphosphonic acid ${ }^{53}$ \\
\hline Atc-AA ${ }^{\mathrm{P}}(\mathrm{OAr})_{2}$ & Diaryl 1-(Arylthiocarbamoylamino)alkylphosphonate ${ }^{a}$ \\
\hline \multirow[t]{2}{*}{$\mathrm{Tc}\left[\mathrm{AA}^{\mathrm{P}}(\mathrm{OAr})_{2}\right]_{2}$} & Tetraaryl Thiocarbamoyl[di(1-aminoalkylphosphonate $)]^{\mathrm{a}}$; \\
\hline & Tetraaryl Thiourylene[dialkyl)diphosphonate)] $]^{29}$ \\
\hline $\mathrm{Tc}-\mathrm{AA}^{\mathrm{P}}(\mathrm{OPh})_{2}$ & 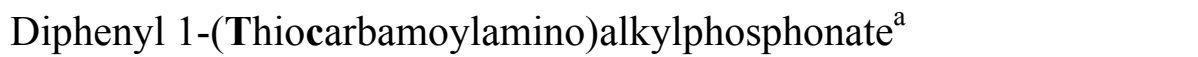 \\
\hline \multirow[t]{2}{*}{$\mathrm{Tc}\left[\mathrm{AA}^{\mathrm{P}}(\mathrm{OPh})_{2}\right]_{2}$} & Tetraphenyl Thiocarbamoyl-[di(aminoalkylphosphonate)] $]^{\mathrm{a}}$; \\
\hline & Tetraphenyl (Thiourylenedialkyl)-diphosphonate) ${ }^{29}$ \\
\hline \multirow[t]{2}{*}{$\mathrm{Tc}\left[\mathrm{Nva}^{\mathrm{P}}(\mathrm{OPh})_{2}\right]_{2}$} & Tetraphenyl Thiocarbamoyl-[di(phosphononorvalinate) $]^{\mathrm{a}}$; \\
\hline & Tetraphenyl (Thiourylenedibutyl)diphosphonate) $)^{16}$ \\
\hline Cm-Hala ${ }^{\mathrm{P}}$ & Carbamoyl-phosponohomoalanine $;$, 1-Ureidopropylphosphonic acid ${ }^{16}$ \\
\hline
\end{tabular}


Table 12. Continued

\begin{tabular}{|c|c|}
\hline $\mathrm{Cm}\left[\mathrm{Ala}^{\mathrm{P}}(\mathrm{OCET})_{2}\right]_{2}$ & $\begin{array}{l}\text { Tetrakis(2-Chloroethyl) Carbamoyl-[di(phosphonoalaninate) }]^{\text {a }} \text {; } \\
\text { Tetrakis(2-Chloroetyl) (Urylenedietyl)diphosphonate }\end{array}$ \\
\hline $\mathrm{Cm}\left[\mathrm{Ala}^{\mathrm{P}}(\mathrm{OPh})_{2}\right]_{2}$ & $\begin{array}{l}\text { Tetraphenyl Carbamoyl-[di(phosphonoalaninate) }]^{\mathrm{a}} \\
\text { Tetraphenyl (Urylenediethyl)diphosphonate }^{16}\end{array}$ \\
\hline $\mathrm{Cm}\left[\operatorname{Pgly}{ }^{\mathrm{P}}(\mathrm{OPh})_{2}\right]_{2}$ & $\begin{array}{l}\text { Tetraphenyl Carbamoyl-[di(phosphonophenylglycinate) }]^{\mathrm{a}} \text {; } \\
\text { Tetraphenyl (Urylenedibenzyl)diphosphonate }\end{array}$ \\
\hline $\mathrm{AA}^{\mathrm{P}}(\mathrm{H}) \mathrm{s}$ & 1-Aminoalkylphosphinic Acids \\
\hline $\operatorname{Ala}^{\mathrm{P}}(\mathrm{H})$ & 1-Aminoethylphosphinic Acid; Phosphinoalanine \\
\hline
\end{tabular}

${ }^{\mathrm{a} C}$ Convention applied in this paper. 'Name formed by analogy to the Birum's nomenclature.

\section{References}

1. Kafarski, P.; Mastalerz, P. Aminoalkanephosphonates: natural occurence, biochemistry and biological properties. Beitrage für Wirkstofforschung 1984, 24, 1.

2. Kafarski, P.; Lejczak, B.: Biological activity of aminophosphonic acids. Phosphorus, Sulfur \& Silicon 1991, 63, 193.

3. Kafarski, P.; Lejczak, B. Aminophosphonic acids of potential medical importance. Curr. Med. Chem.-Anti-Cancer Agents 2001, 1, 301.

4. (a) Jane, D. Neuroactive aminophosphonic and aminophosphinic acid derivatives. In Book: Amino-phosphonic and aminophosphinic acids. Chemistry and biological activity; Kukhar, V. P.; Hudson, H. R. Eds.; Wiley: Chichester, New York, 2000; \&14, pp .483-536. (b) Oleksyszyn, J. Aminophosphonic and aminophosphinic acid derivatives in the design of transition state analogue inhibitors: biomedical opportunities and limitations. Ibid \& 15, 537558. (c) Peyman, A. Aminophosphonic and aminophosphinic acids in the design and synthesis of HIV protease inhibitors. Ibid. \&16, 559-578. (d) Markwell, R. Aminophosphonic and aminophosphinic acid derivatives as inhibitors of human colagenases. Ibid. \&18, 597-617. (e) Green, D. S. C.; Skordalakes, E., Scully, M. F.; Deadman, J. J. Aminophosphonic acid derivatives as antithrombic agents. Ibid. \&17, 579596.

5. Franz, J. E. Herbicidal compositions and methods employing esters of N-phosphonoglycine. Pat US 3997860 (1976); Chem. Abstr. 1976, 86, 43812.

6. (a) Franz, J. E. In Book: Discovery, development and chemistry of glyphosate, The herbicide glyphosate; Grossbard, E.; Atkinson, D. Eds.; Butterworth: Boston, MA, 1985; pp1-17. (b) Sikorski, J. A.; Logush, E. W. Aliphatic carbon-phosphorus compound as herbicides. In Book: Handbook in organophosphorus chemistry. Engel, R. Ed.; Dekker: New York; 1988, \&15, pp737-806. (c) Hudson, H. R. Aminophosphonic and aminophosphinic acids and their derivatives as agrochemicals. In Book: Aminophosphonic and aminophosphinic acids. 
Chemistry and biological activity. Kukhar, V. P.; Hudson, H. R., Eds. Wiley: Chichester, New York, 2000; \&13, 443-482. (d) Gancarz, R. Kabachnik-Fields reaction. Synthesis of biologically active aminophosphonates. Pr. Nauk. Inst. Chem. Org. Biochem. Biotechnol. Polit. Wrocław 1997, 39, 1.

7. Lamberth, C. Amino acid chemistry in crop protection. Tetrahedron 2010, 37, 7239.

8. (a) Allen, J. G.; Atherton, F. R.; Hall, M. J.; Hassal, C. H.; Holmes, S. W.; Lambert, R. W.; Nisbet, L. J.; Ringrose, P. S. Phosphonopeptides, a new class of synthetic antibacterial agents. Nature 1978, 272, 56. (b) Atherton, F. R.; Hall, M. J.; Hassall, C. H.; Lambert, R. W.; Ringrose, P. S. Phosphonopeptides as antibacterial agents: rationale, chemistry, and structure-activity relationships. Antimicrob. Agents Chemother. 1979, 15, 677.

9. Kafarski, P.; Lejczak, B. The biological activity of phosphono- and phosphinopeptides. In Book: Aminophosphonic and aminophosphinic acids. Chemistry and biological activity. Kukhar, V. P.; Hudson, H. R. Eds.; Wiley: Chichester, New York, 2000; \& 12, 407-442.

10. (a) Petrov, K. A.; Chauzov, V. A.; Erokhina, T. E. Aminoalkyl organophosphorus compounds. Usp. Khim. 1974, 43, 2045. (b) Kabachnik, M. I.; Medved, T. Y.; Dyatlova, N. M.; Rudomino, M. V. Phosphoroorganic complexones. Usp. Khim., 1974, 43, 1554. (c) Prajer, K.; Rachoń, J. $\alpha$-Aminophosphonic acids. Z. Chem. 1975, 15, 209. (d) Kukhar, V. P.; Solodenko, V. A. The phosphorus analogues of aminocarboxylic acids. Usp. Khim. 1987, 56, 1504. (e) Mastalerz, P. a-Substituted phosphonates. In Book: Handbook in organophosphorus chemistry; Engel, R. Ed.; Dekker: New York, 1988; \&7, 276-375. (f) Kafarski, P.; Zoń, J. Synthesis of $\alpha$-aminoalkanephosphonic and $\alpha$-aminoalkylphosphinic acids. In Book: Aminophosphonic and aminophosphinic acids. Chemistry and biological activity. Kukhar. V. P.; Hudson, H. R. Eds.; Wiley: Chichester, New York, 2000; 2\&, 33-74. (g) Kukhar, V.P. Synthesis of $\alpha$-aminoalkanephosphonic and $\alpha$-aminoalkanephosphinic acids with the amino substituents in other than $\alpha$-position. Ibid \&3, 75-102. (h) Lall, Sh.; Engel, R. $\alpha$-Amino acid analogues bearing side-chain C-P linkages. Ibid \&4, 103-126. (i) Kudzin, Z. H. 1-Aminoalkanephosphonic acids: Six decades of exploration. Sci. Issues, Acad. J. Dtugosza, Częstochowa, 2005, IX, 29. (j) Mazurkiewicz, R.; Kuźnik, K.; Grymel, M.; Październiok-Holewa, A. $\alpha$-Amino acid derivatives with a $\mathrm{C} \alpha-\mathrm{P}$ bond in organic synthesis. Arkivoc 2007, vi, 193. (k) Zefirov, N. S.; Matveeva, E. D. Catalytic KabachnikFields reaction: new horizons for old reaction. Arkivoc 2008, i, 1. (1) Kudzin, Z. H.; Kudzin, M. H.; Drabowicz, J.; Stevens, C. Aminophosphonic acids - phosphorus analogues of natural amino acids. Syntheses of $\alpha$-aminophosphonic acids. Curr. Org. Chem. 2010 (in press).

11. (a) Dhavan, B.; Redmore, D. Optically active 1-aminoalkylphosphonic acids. Phosphorus, Sulfur \& Silicon 1987, 32, 119. (b) Kukhar, V. P.; Svistunova, Ya. N.; Solodenko, V. A.; Soloshonok, V. A. Asymmetric synthesis of fluoro- and phosphoroorganic analogs of amino acids. Usp. Khim. 1993, 62, 284 [Russ. Chem. Rev. 1993, 62, 261]. (c) Uziel, J.; Genet, J. P. Synthesis of racemic and optically active $\alpha$-aminophosphonic acids. Zh. Org. Khim. 1997, 33, 1605. (d) Kukhar, V. P. Asymmetric synthesis of aminophosphonic and 
aminophosphinic acids. In Book: Aminophosphonic and aminophosphinic acids. Chemistry and biological activity; Kukhar, V. P.; Hudson, H. R. Eds.; Wiley: Chichester, New York, 2000; \&5, pp 127. (e) Mikołajczyk, M.; Drabowicz, J.; Lyzwa, P. Asymmetric synthesis of phosphonic analogs of $\alpha$-amino acids. In Book: Enantioselective synthesis of $\alpha$-amino acids. Juaristi, E.; Soloshonok, V. A. Eds.; Wiley: Hoboken, N. J., 2005; 261-276. (f) Ma, J.-N. Catalytic asymmetric synthesis of $\alpha$ - and $\beta$-aminophosphonic acid derivatives. Chem. Soc. Rev. 2006, 35, 630. (g) Ordonez, M.; Rojas-Cabrera, H.; Cativiela, C. An overview of stereoselective synthesis of $\alpha$-aminophosphonic acids and derivatives. Tetrahedron 2009, $65,17$.

12. (a) Galushko, S. V. Column chromatography of aminophosphonic acids and peptides. In: Aminophosphonic and aminophosphinic acids. Chemistry and biological activity; Kukhar. V. P.; Hudson, H. R. Eds.; Wiley: Chichester, New York, 2000; \&7, pp205-216. (b) Hägele, G. Physical properties and NMR characterization of aminophosphonates and aminophosphinates. Ibid \&8, 217-284. (c) Kiss, T.; Lazar I. Stability constants of metal complexes in solution. Ibid \&9, 285-326. (d) Choi, N.; Mc Partlin, M. X-Ray crystallographic studies. Ibid \&10, 327-362. (e) Kudzin, Z. H.; Sochacki, M. Mass Spectrometry and Gas Chromatography-Mass Spectrometry of aminoalkanephosphonic acids. Ibid \& 11, 363-406.

13. Kudzin, Z. H.; Depczyński, R.; Andrijewski, G.; Drabowicz, J. Aminoalkanephosphonates. 1-( $N$-acylamino)alkanephosphonates. The synthesis via $N$-acylation of 1-aminoalkanephosphonic acids. Pol. J. Chem. 2005, 79, 529.

14. Kudzin, Z. H.; Depczyński, R.; Kudzin, M. H.; Drabowicz, J.; Łuczak, J. 1-(NTrifluoroacetylamino)alkylphosphonic acids. Synthesis and properties. Amino Acids 2007, 33,663 .

15. Kudzin, Z. H.; Depczyński, R.; Kudzin, M. H.; Drabowicz, J. 1-(N-Chloroacetylamino)alkylphosphonic acids - synthetic precursors of glycylophosphono-peptides and related compounds. Amino Acids 2008, 34, 163.

16. Birum, G. H. Urylenediphosphonates. A general method for the synthesis of $\alpha$-ureidophosphonates and related structures. J. Org. Chem. 1974, 39, 209.

17. Birum, G. H. Nitrogen-containng organophosphorus compounds having aryloxy substituents bonded to phosphorus in ester structures. Pat US, 4036913, (1973); Chem. Abstr. 1977, 87, 201764.

18. Birum, G. H. Phosphorus compounds. Pat US, 4031170, (1973); Chem. Abstr. 1977, 87, 135932.

19. Birum, G. H. Proces for the production of sulfonamide phosphonates. Pat US, 4032601, (1973); Chem. Abstr. 1977, 87, 135933.

20. Birum, G. H. Urea-phosphorus compounds. Pat US, 3904654, (1973); Chem. Abstr. 1976, $84,44349$.

21. Birum, G. H. Urea-phosphorus compounds. Pat US, 3965127, (1973); Chem. Abstr. 1976, $85,143295$. 
22. Huber, J. W. III; Middlebrooks, M. Synthesis of aminoalkylphosphonic acids from ureidoalkanephosphonates. Synthesis 1977, 883.

23. Oleksyszyn, J.; Tyka, R. An improved synthesis of 1-aminophosphonic acids. Tetrahedron Lett. 1977, 2823.

24. Oleksyszyn, J.; Subotkowska, L.; Mastalerz, P. Diphenyl 1-aminoalkanephosphonates. Synthesis 1982, 985.

25. Oleksyszyn, J. Amidoalkylation of trivalent phosphorous compounds. Pr. Nauk. Inst. Chem. Org. Fiz. Politech. Wrocław. 1986, 29, 1.

26. Engelmann, M.; Pikl, J. Phosphonic acids derived from organic acylamidomethyl compounds. Pat US, 2304156 (1942); Chem. Abstr. 1943, 37, 3261.

27. Pikl, J. Amino- and methylaminomethanephosphonic acids and derivatives. Pat US, 2328358 (1943); Chem. Abstr. 1944, 38, 754.

28. Oleksyszyn, J.; Tyka, R.; Mastalerz, P. Direct synthesis of 1-aminoalkylphosphonic and phosphinic acids from phosphorus trichloride or dichlorophosphines. Synthesis 1978, 479.

29. Kudzin, Z. H.; Stec, W. J. Synthesis of 1-aminoalkanephosphonic acids via thioureidoalkanephosphonates. Synthesis 1978, 469.

30. Kudzin, Z. H. Investigations in the domain of aminophosphonic acids. WNUŁ 1996, 1.

31. Stec, W. J.; Lesiak, K. A novel route to 1-aminoalkylphosphonic acids. J. Org. Chem. 1976, $41,3757$.

32. Kotyński, A.; Stec, W. J. Synthesis of enantiomers of 1-amino-2-phenylethylphosphonic acid. J. Chem. Res. 1978, 41.

33. Kotyński, A.; Stec, W. J. Synthesis of 1-aminoethylphosphonic acid. Pol. J. Chem. 1978, $52,659$.

34. Leśniak, K., Stec, W. J.; Zieliński, W. S. Synthesis of 5'-O-(R,S)-(1-aminoethane-1phosphonyl)-uridine and adenosine. Pol. J. Chem. 1979, 53, 327.

35. Bogemann, M.; Petersen, S.; Schultz, O.-E.; Soll, W.: Methoden der organischen Chemie (Houben-Weyl) Hersg. Miller E.; Georg Thieme Verlag: Stuttgart, 1955; Bd IX (24), p. 801.

36. Schroeder, D. Ch. Thioureas. Chem. Rev. 1955, 55, 180.

37. Chęcińska, L.; Małecka, M.; Olszak, T.; Kudzin, Z. H. O,O-Diphenyl 2-methyl-1-(3phenylthioureido)propanephosphonate. Acta Crystallogr. E 2001, 57, 1213.

38. Chęcińska, L.; Małecka, M.; Olszak, T.; Kudzin, Z. H. O,O-diphenyl 1-(3phenylthioureido)ethanephosphonate. Acta Crystallogr. E 2001, 57, 1216.

39. Chęcińska, L.; Sieroń, L.; Bukowska-Strzyżewska, M.; Kudzin, Z. H.; Fabian, L. Two derivatives of ( $N$-phenylthioureidoalkyl)phosphonates. Acta Crystallogr. Sect. C 2003, C59, 046.

40. Chęcińska, L.; Grabowski, S. J.; Małecka, M. An analysis of bifurcated H-bonds: crystal and molecular structures of $O, O$-diphenyl 1-(3-phenylthioureido)pentanephosphonate and 1-(3phenylthioureido)butanephosphonate. J. Phys. Org. Chem. 2003, 16, 213.

41. Chęcińska, L.; Fabian, L.; Kudzin, Z. H. Structural studies of ( $N$-phenylthioureidoalkyl- and aryl)phosphonates. Acta Crystallogr. B 2004, 60, 211. 
42. Chęcińska, L.; Grabowski, S. J. Partial hydrogen bonds. Structural studies on thioureidoalkanephosphonates. J. Phys. Chem. 2005, 109, 2942.

43. Lejczak, B. Biological activities of aminophosphonates and phosphonopeptides. Pr. Nauk. Inst. Chem. Org. Biochem. Biotechnol. Politech. Wroclaw. 1988, 35, 1.

44. (a) Maier, L.; Diel, P. Preparation, physical and biological properties of aminoarylmethylphosphonic and -phosphonous acids. Phosphorus, Sulfur \& Silicon 1991, 57, 57. (b) Maier, L.; Diel, P.J. Synthesis, physical and biological properties of the phosphorus analogues of phenylalanine and related compounds. Phosphorus, Sulfur \& Silicon 1994, 90, 259.

45. Kafarski, P.; Lejczak, B.; Tyka, R.; Koba, L.; Pliszczak, E.; Wieczorek, P. Herbicidal activity of phosphonic, phosphinic, and phosphonous acid analogs of phenylglycine and phenylalanine. J. Plant Growth Regul. 1995, 14, 199.

46. Zoń, J.; Amrhein, N.; Gancarz, R. Inhibitors of phenylalanine ammonia-lyase: 1-aminobenzylphosphonic acids substituted in the benzene ring. Phytochemistry 2002, 59, 9.

47. Asano, S.; Kitahara, T.; Ogawa, T.; Matusi, M. The new synthesis of $\alpha$-amino phosphonic acids. Agric. Biol. Chem. 1973, 37, 1193.

48. Soroka, M. The synthesis of 1-aminoalkylphosphonic acids. A revised mechanism of the reaction of phosphorus trichloride, amides and aldehydes or ketones in acetic acid solution (Oleksyszyn reaction). Liebigs Ann. Chem. 1990, 4, 331.

49. Kudzin, Z. H.; Kotyński, A. Synthesis of $O, O$-dialkyl 1-aminoalkanephosphonates. Synthesis 1980, 1028.

50. Łukszo, J.; Tyka R. New protective group in the synthesis of 1-aminoalkylphosphonic acids. Synthesis 1977, 239.

51. Ryglowski, A.; Kafarski, P. Preparation of 1-aminoalkylphosphonic acids and 2aminoalkylphosphonic acids by reductive amination of oxoalkylphosphonates. Tetrahedron 1996, 52, 10685.

52. Oleksyszyn, J.; Tyka, R.; Mastalerz, P. Guanidinophosphonic acids. Synthesis 1977, 571

53. Oleksyszyn, J.; Tyka, R. 1-(S-Alkylisothioureido)benzylphosphonic acids as special guanidylation agents. A general method for the synthesis of 1-guanidinobenzylphosphonic acids substituted in N'-position. Pol. J. Chem. 1978, 52, 1949.

54. Cameron, D. G.; Hudson, H. R.; Ojo, I. A. O.; Pianka, M. Organophosphorus compounds as potential fungicides. Aminoalkane-, guanidinoalkane-, and thioureidoalkanephosphonic acids: preparation, spectroscopy, and fungicidal activity. Phosphorus, Sulfur \& Silicon 1988, 40, 183.

55. Kudzin Z. H. Phosphocysteine derivatives. Thioureidoalkanephosphonates via acetals. Synthesis 1981, 643.

56. Kudzin, Z. H.; Stec, W. J. Phosphohomocysteine derivatives. Synthesis 1980, 1032.

57. Kudzin, Z. H.; Mokrzan, J.; Skowroński, R. Long chain aminothiaalkane-phosphonates, their sulphinyl and sulphonyl derivatives. A new class of complexane type surfactants. Phosphorus, Sulfur \& Silicon 1989, 42, 41. 
58. Tam, C. C.; Mattocks, K. L.; Tishler, M. Synthesis of phosphonomethionine and related compounds. Synthesis 1982, 188.

59. Kudzin, Z. H.; Stec, W. J. Phosphocysteine and phosphohomocysteine. Synthesis and isolation. Synthesis 1983, 812.

60. Zygmunt, J.; Mastalerz, P. 1-Amino-2-mercaptoethanephosphonic acid, the phosphonic analogue of cysteine. Pol. J. Chem. 1981, 55, 713.

61. Zygmunt, J. Aziridine-2-phosphonic acid. The valuable synthesis of 1-amino-2functionalized ethanephosphonic acids. Tetrahedron 1985, 31, 4979.

62. Kudzin, Z. H., Saganiak. M.; Andrijewski, G.; Drabowicz, J. Oxidative transformations of phosphonocysteine and phosphonohomocysteine. Synthesis and isolation of phosphonocysteic and phosphonohomocysteic acids. Pol. J. Chem. 2005, 79, 499.

63. Kudzin, Z. H.; Kudzin, M. H.; Urbaniak, P.; Drabowicz, J. Oxidative dephosphonylation of 1-aminoalkylphosphonic acids by means of aqueous bromine. Amino Acids, 2010 (submission).

64. Kudzin, Z.H.; Andrijewski, G.; Drabowicz, J.: 1-Aminothiaalkanephosphonic acids sulphinyl and sulphonyl derivatives. Synthesis and acidic properties. Heteroatom Chem. 1994, 5,1 .

65. Saganiak, M. Investigations on sulphur-containing 1-aminoalkylphosphonic acids. $\mathrm{PhD}$ Dissertation, University of Łódź, Poland, Łódź, 2005.

66. Drabowicz, J.; Kielbasinski,P.; Mikojajczyk M. In Book: The Chemistry of Sulfones and Sulfoxides; Patai, S.; Rapaport, Z. Eds.; Wiley: Chichester, UK, 1988.

67. Venier, C. G.; Squires,T, G.; Chen, Y. Y.; Smith, B. F. Peroxytrifluoroacetic acid oxidation of sulfides to sulfoxides and sulfones. J. Org. Chem. 1982, 47, 3773.

68. Alferon, K. V.; Zhukov, Y. N.; Khurs, E. N.; Osipova, T. I.; Khomutov, R.W. Synthesis of phosphonic and phosphinic analogs of homoserine. Izv. Akad. Nauk SSSR, Ser. Khim 2001, 301.

69. Kudzin, Z. H.; Saganiak, M., 2005, unpublished results.

70. Nowakowski, M.; Tishler, M.; Domeyko, A. M. The Synthesis and biological activity of $S$ alkylphosphonohomocysteine sulfoximides. Phosphorus, Sulfur \& Silicon 1989, 45, 183.

71. Kudzin, Z. H.; Kotyński, A.; Andrijewski, G. Aminoalkanediphosphonic acids. Synthesis and acidic properties. J. Organometal. Chem. 1994, 477, 199.

72. Issleib, K.; Dopferm, K. P.; Balszuweit, A. Amino-diphosphonic and diamino-diphosphonic acids - synthesis and transamination. Phosphorus, Sulfur \& Silicon 1983, 14, 171.

73. Kudzin, Z. H.; Majchrzak M. 1-Aminoalkanephosphonic acids. Addition of diethyl phosphite to $N$-diisobutylaluminio-aldimines. J. Organometal. Chem. 1989, 376, 246.

74. Przybylak, S. Investigations on convertion of 4-cyanobutanal into $\mathrm{Hgly}^{\omega-\mathrm{P}}$ acids. Mgr thesis, University of Łódź, Poland, Łódź, 2009.

75. Zingle, C.; Kuntz, L.; Tritsch, D.; Grosdemange-Billiard, C.; Rohmer, M. Isoprenoid biosynthesis via the methylerythritol phosphate pathway: structural variations around 
phosphonate anchor and spacer of Fosmidomycin, a potent inhibitor of Deoxyxylulose Phosphate Reductoisomerase. J. Org. Chem. 2010, 75, 3203.

76. Kudzin, Z. H.; Kudzin, M. H.; Urbaniak, P.; Drabowicz, J. Synthesis and rearrangements of 1-amino- $\omega$-nitroalkanephosphonates. Amino Acids 2011 (submission).

77. Huber, J. W. III; Gilmore, W. F. Optically active $\alpha$-aminophosphonic acids from ureidophosphonates. Tetrahedron Lett. 1979, 3049.

78. Oshikawa, T.; Yamashita, M. Preparation of optically active 1-aminoalkyl-phosphonic acids from chiral carbamates and chiral ureas. Bull. Chem. Soc. Jpn. 1989, 62, 3177.

79. Crutchfield, M. M.; Dungan, C. H.; Letcher, J. H.; Mark, V.; Van Wazer J. R. Compilation of ${ }^{31} \mathrm{P}$ NMR data. In Book: Topics in phosphorus chemistry; Wiley: New York, 1967; 5, 177.

80. Oleksyszyn, J.; Subotkowska, L. Aminomethanephosphonic acid and diphenyl ester. Synthesis 1982, 908.

81. Oleksyszyn, J.; Powers, J. C. Irreversible inhibition of serine protoases by peptide derivatives of $\alpha$-aminoalkylphosphonate diphenyl esters. Biochem. Biophys. Res. Commun. 1989, $161,143$.

82. Oleksyszyn, J.; Powers, J. C. Irreversible inhibition of serine protoases by peptide derivatives of ( $\alpha$-aminoalkyl)phosphonate diphenyl esters. Biochemistry 1991, 30, 485.

83. Oleksyszyn, J.; Boduszek, B.; Kam, Ch.-M.; Powers, J. C. Novel amidine-containing peptidyl phosphonate as irreversible inhibitors of blood coagulation and related serine protoases. J. Med. Chem. 1994, 37, 226.

84. Bergin, C.; Hamilton, R.; Walker, B.;. Walker, B. J. Synthesis of diphenyl phosphonate analogues of tyrosine and tryptophan and derived peptides as chymotrypsin inhibitors. Chem. Commun. 1996, 1155.

85. Boduszek, B. An efficient method of synthesis of 1-aminophosphonic acids and esters bearing heterocyclic moiety. Phosphorus, Sulfur \& Silicon 1995, 104, 63.

86. Boduszek, B. Aminophosphonic acids bearing a heterocyclic moiety. Synthesis of pyridine, pyrazole and imidazole derivatives. Phosphorus, Sulfur \& Silicon 1996, 113, 209.

87. Boduszek, B.; Lipiński, M.; Kowalska, M. W. Aminophosphonic derivatives of chromone3-( $\alpha$-amino)methanephosphonic acids. Phosphorus, Sulfur \& Silicon 1998, 143, 179.

88. Wang, Ch.-L. J.; Taylor, T. L.; Mical, A. J.; Spitz, S.; Reilly, T. M. Synthesis of phosphonopeptides as thrombin inhibitors. Tetrahedron Lett. 1992, 33, 7667.

89. Hamilton, R.; Kay, G.; Schute, R.; Travers, J.; Walker, B.; Walker, J. B. The synthesis of phosphonate analogs of amino acids and peptides. Phosphorus, Sulfur \& Silicon 1993, 76, 127.

90. Hamilton, R.; Walker, B. J.; Walker, B. Convenient synthesis of $N$-protected diphenyl phosphonate esters - analogues of ornithine, lysine and homolysine. Tetrahedron Lett. 1993, 34, 2847.

91. Sienczyk, M.; Kliszczak, M.; Oleksyszyn, J. Synthesis of isocyanide derivatives of $\alpha$-aminoalkylphosphonate diphenyl esters. Tetrahedron Lett. 2006, 47, 4209. 
92. Goldmann, P.: Iminium salts in synthesis of organophosphorus compounds. PhD thesis, Technical University of Wroclaw, Poland, Wroclaw, 2005.

93. Van der Veken, P.; El Sayed, I.; Joossens, J.; Stevens, Ch. V.; Augustyns, K. Lewis acid catalyzed synthesis of $\mathrm{N}$-protected diphenyl 1-aminoalkylphosphonates. Synthesis 2005, 634.

94. Boduszek, B. Heterocyclic aminophosphonic acids - synthesis and biological activity. Pr. Nauk. Inst. Chem. Org. Biochem. Biotechnol. Politech. Wroclaw. 1997, $38,1$.

95. Moriarty, R. M.; Liu, K.; Zhuang, H.; Lenz, D.; Brimfield, A.; Xia, Ch. Synthesis of unsymmetrical substituted $\alpha$-aminoalkylphosphonate esters. Synth. Commun. 1995, 25, 2763.

96. Zoń, J. Research on the syntheses and properties of inhibitors and substrates of phenylalanine ammonia-lyase. Pr. Nauk. Inst. Chem. Org. Biochem. Biotechnol. Politech. Wrocław. 2005, 42, 3.

97. Yuan, Ch.; Qi, Y. A facile synthesis of $\alpha$-amino-substituted benzylphosphonic and phosphinic acids by use of thiophosphoramide. Synthesis 1986, 821.

98. Miao, Z.; Wang, B.; Zhang, G.; Chen, R. An improved route to the synthetic of diphenyl $\alpha-$ diethoxythiophosphorylamino)methylphosphonates. Bioorg. Chem. 2006, 34, 167.

99. Cui, Z. W.; Zhang, J. F.; Miao, Z. W.; Chen, R. Y. Synthesis of diphenyl alpha(dipropoxyphosphoramido)alkylphosphonates. Chin. J. Chem. 2007, 25, 1551.

100.Belyaev, A.; Borloo, M.; Augustyns, K.; Lernbeir, A.-M.; De Meester, I.; Scharpe, S.; Blatob, N.; Peeters, O. M.; De Ranter, C.; Haemers, A. A new synthetic method for proline diphenyl phosphonate. Tetrahedron Lett. 1997, 46, 133.

101.Lu, S.-M.; Chen, R.-Y. Facile and efficient synthesis of $\alpha$-aminophosphonate derivatives of 1,3,4-oxadiazole and 1,3,4-thiadiazole. Org. Prep. Proced. Int. 2000, 32, 302.

102. Oleksyszyn, J.; Soroka, M.; Rachoń. J. Phosphonic analogues of amino acids and peptides. Phosphoro- and phosphine analogues of cyclolecine. Chimia 1978, 32, 253.

103. Oleksyszyn, J.; Gruszecka, E.; Kafarski, P.; Mastalerz, P. New phosphonic analogus of aspartic and glutamic acid by amidoalkilation of trivalent phosphorus chlorides with ethyl acetylacetate and ethyl levulinate. Monatsh. Chem. 1982, 113, 59.

104.Oleksyszyn, J.: 1-( $N$-alkylaminoalkane)phosphonic and 1-( $N$-alkylaminoalkane $)$ phenylphosphinic acids. Synthesis 1980, 722.

105. Oleksyszyn, J. An amidoalkylation of trivalent phosphorus compounds with $\mathrm{P}(\mathrm{O}) \mathrm{H}$ functions including acetic acid solutions of $\mathrm{PCl}_{3}, \mathrm{RPCl}_{2}$ or $\mathrm{R}_{2} \mathrm{PCl}$, diesters of phosphorous acid and phosphorous-(III)-acids. J. Prakt. Chem. 1987, 329, 19.

106. Oleksyszyn, J.; Gruszecka, E. Amidoalkylation of phosphorous acid. Tetrahedron Lett. 1981, 22, 3537.

107. Soroka, M. Selected problems of chemistry of aminophosphonic acids. Pr. Nauk. Inst. Chem. Org. Fiz. Politech. Wrocław, 1987, 32, 1.

108. Soroka, M. Comments on the synthesis of aminomethylphosphonic acid. Synthesis 1989, 547. 
109. Soroka, M.; Jaworska, D.; Szczęsny, Z. Synthesis of 1-aminoalkylphosphonic acids via amidoalkylation of phosphorous amid by $N, N$ '-alkylidenebisamides. Liebigs Ann. Chem. 1990, 4, 1153.

110. Tyka, R.; Hägele, G. A convenient synthesis of $N$-alkylaminomethanephosphonic and $N$ alkylaminomethylphosphinic acids. Synthesis 1984, 218.

111. Tyka, R.; Hägele, G. Synthesis of aminobenzylphosphonous acids via direct amidoalkylation of hypophosphorous acid. Phosphorus, Sulfur \& Silicon 1989, 44, 103.

112. Tyka, R.; Hägele, G.; Peters, J. $N$-alkyl- $N$-phosphonomethyleneaminomethyl phosphinic acid. Phosphorus, Sulfur \& Silicon 1987, 34, 31.

113.Lejczak, B.; Kafarski, P.; Soroka, M.; Mastalerz, P. Synthesis of the phosphonic analogue of serine. Synthesis 1984, 577.

114.Sosnowsky, G.; Łukszo, J.; Ravela, E.; Zuretti, M. F. In the search for anticancer drugs. 13. Phosphonic and phosphinic analogue of lysine. J. Med. Chem. 1985, 28, 1350.

115.Yuan, Ch. Y.; Qi, M. An improved route to of 1-amino-substituted benzyl phosphonic and phosphinic acids. Synthesis 1988, 472.

116.Diel, P. J.; Maier, L. Synthesis and properties of $\alpha$-amino- $\omega$-carboxyalkylphosphonic and phosphinic acids. Phosphorus, Sulfur \& Silicon 1987, 29, 201.

117. Yuan, Ch.; Wang, G. Studies on organophosphorus compounds. XLI. A convenient synthesis of alkyl hydrogen $\alpha$-(benzyloxycarbonylamino)benzylphosphonates. Synthesis $1990,256$.

118.Zoń, J.; Amrhein, N. Inhibitors of phenylalanine ammonia-lyase. 2-Aminoindan-2phosphonic acid and related compounds. Liebigs Ann. Chem. 1992, 625.

119.Green, D.; Gruss, U.; Hagele, G.; Hudson, H.R.; Lindblom, L.; Pianka, M. The preparation and characterization of some fluorinated $\alpha$-aminoarylmethanephosphonic acids. Phosphorus, Sulfur \& Silicon 1996, 113, 179.

120.Chung S.-K., Kang D.-H. Asymmetric synthesis of $\alpha$-aminophosphonates via diastereoselective addition of phosphite to chiral imine derivatives. Tetrahedron: Asymmetry 1996, 7, 21.

121. Onyshko, P. P. Synthesis of ( $\alpha$-acylamino)polyhaloalkylphosphoryl compounds by the reaction of trivalent phosphorus chlorides with $N$-(hydroxypolyhaloalkyl)amides. Russ. Chem. Bull. 1998, 47, 1763 [Izv. Akad. Nauk, Ser. Khim. 1998, 47, 1810].

122. Burzynska, A.; Wit, M.; Wojtasek, H.; Kafarski, P. Phosphonic acid analogues of tyrosine and dihydroxyphenylalanine (DOPA) as tyrosinase inhibitors. Phosphorus, Sulfur \& Silicon 2002, $177,1937$.

123.Liu, H.; Xu, J. X. Synthesis of 1-(N-ethoxycarbonylamino)alkylphosphonic monoesters. Amino Acids 2005, 29, 241.

124.Ziora, Z.; Kafarski, P. Amidoalkylation of phosphorus trichloride with acetamide and alkyl oxocycloalkanecarboxylates. Phosphorus, Sulfur \& Silicon 2009, 184, 1047.

125.Dai, Q.; Wo, H.; Chen, R. Synthesis of cyclic esters of $N$-toluenesulfonyl- $\alpha$-aminophosphonic acids. Heteroatom. Chem. 1998, 9, 511. 
126.Dai, Q.; Chen, R.-Y. Synthesis of $O, O$-diphenyl $\alpha$-(p-toluenesulfonyl)-amino-(substituted)phenylmethylphosphonates. Heteroatom Chem. 1997, 8, 203.

127.Swamy, K. C. K.; Kumaraswamy, S.; Kumar, K. S.; Mutiah, C. Cyclic chlorophosphites as scaffolds for the one-pot synthesis of $\alpha$-aminophosphonates under solvent-free conditions. Tetrahedron Lett. 2005, 46, 3347.

128.Naydenova, E.; Topashka-Ancheva, M.; Todorov, P.; Yordanova, T.; Troev, K. Novel $\alpha-$ amino-phosphonic acids. Design, characterization, and biological activity. Bioorg. \& Med. Chem. 2006, 14, 2190.

129. Todorov, P. T.; Naydenova, E. D.; Troev, K. D. Synthesis of novel aminophosphonic acids with hydantoin structure. Heteroatom Chem. 2009, $20,87$.

130. Naydenova, E. D.; Todorova, P. T.; Troev, K. D. Synthesis and characterization of novel cycloalkanespiro-5-hydantoin phosphonic acids. Phosphorus, Sulfur \& Silicon 2010, 185, 1315.

131.Xu, J.; Ma, Y.; Duan, L. A novel synthetic route to $N$-protected 1-aminoalkyl-phosphonates. Heteroatom Chem. 2000, 11, 417.

132.Liu, H.; Cai, S.; Xu, J. Asymmetric synthesis of $N$-protected chiral 1-aminoalkylphosphonic acids and synthesis of side chain-functionalized depsiphosphonopeptides. J. Peptide Sci. 2006, 12, 337

133.Cai, S.; Yin, W.; Ma, Y.; Liu, H.; Zhao, Y.; Xu, J. Synthesis and Mass Spectrometry of 2hydroxyethyl 1-aminoalkylphosphonates. Phosphorus, Sulfur \& Silicon 2007, 182, 25.

134.Fu, N.; Zhang, Q.; Duan, L.; Xu, J. Facile synthesis of phosphonamidate- and phosphonatelinked phosphonopeptides. J. Peptide Sci. 2006, 12, 303.

135.Xu, J.; Gao, Y. Straightforward synthesis of depsiphosphonopeptides via Mannich-type multicomponent condensation. Synthesis 2006, 783.

136. Dai, Q.; Chen, R. A facile synthesis of phenyl hydrogen $\alpha$-(benzyloxycarbonylamino)benzylphosphonates. Synth. Commun. 1997, 27, 1653.

137. Yuan, Ch.; Wang, G.; Chen, S. Studies on organophosphorus compounds. A facile and direct route to dialkyl 1-(benzyloxycarbonylamino)alkylphosphonates and dialkyl or diphenyl $\alpha$-(benzoxycarbonylamino)benzylphosphonates. Synthesis 1990, 522.

138. Huang, J.; Chen, R. An overview of recent advances on the synthesis and biological activity of aminophosphonic acid derivatives. Heteroatom Chem. 2000, 11, 480.

139. Yuan, Ch.; Chen, S. Studies on organophosphorus compounds. LXIII. A new and facile synthetic route to proected phosphonopeptides: A backbone for the formation of oligophosphonopeptides. Synthesis 1992, 1124.

140. Schmidt, U.; Liberknecht, A.; Wild, J. Synthesis of dehydroamino acids and amino acids from $\mathrm{N}$-acyl-2-(dialkoxyphosphinyl)glycine esters. Synthesis 1984, 53.

141.Pulver, M. J.; Balthazor, T. M. A convenient synthesis of aminomethylphosphonic acid. Synth. Commun. 1986, 16, 733.

142. Subotkowski, W.; Tyka, R.; Mastalerz, P. Phosphonic analogue of proline. Pol. J. Chem. 1980, 54, 503. 
143.Petrillo, E. W.; Karanevsky, D. C.; Spitzmiller, E. R.; Dugan, M. E. Preparation of Nprotected 1-aminoalkylphosphinic acid and their conversion to novel inhibitors of angiotensin-converting enzyme. Phosphorus, Sulfur \& Silicon 1983, 18, 489.

144.Chen, Sh.; Coward, J. K.:A general method for the synthesis of $N$-protected $\alpha$-aminoalkylphosphinic acids. Tetrahedron Lett. 1996, 37, 4335.

145.Chen, Sh.; Coward, J. K. Investigations on new strategies for the facile synthesis of polyfunctionalized phosphinates: phosphinopeptide analogues of glutathionyl-spermidine. $J$. Org. Chem. 1998, 63, 502.

146.Dmitriev, M. E.; Ragulin V. V. New opinions on the amidoalkylation of hydro-phosphorylic compounds. Tetrehedron Lett. 2010, 51, 2613.

147.Azizi, N.; Saidi, M. R. Lithium perchlorate-catalyzed three-component coupling. A facile and general method of synthesis of $\alpha$-aminophosphonates. Eur. J. Org. Chem. 2003, 4630.

148. Azizi, N.; Saidi, M. R. Synthesis of tertiary $\alpha$-amino phosphonate by one-pot threecomponent coupling mediated by LPDE. Tetrahedron 2003, 59, 5329.

149.Heydari, A.; Mehrdad, M.; Schaffie, M.; Abdolrezai, M. S., Hajinassirei, R. The binary reagent $(\mathrm{MeO})_{3} \mathrm{P} / \mathrm{Me}_{3} \mathrm{SiCl}$ and $(\mathrm{MeO})_{3} \mathrm{P} / \mathrm{CH}_{3} \mathrm{CO}_{2} \mathrm{H}$ in $0.5 \mathrm{M}$ lithium perchlorate/diethyl ether. An efficient route to the preparation of $\alpha$-hydrazinophosphonates and $N$-hydroxy- $\alpha$ aminophosphonates. Chem. Lett. 2002, 1146.

150.Akbari, J.; Heydari, A. A sulfonic acid functionalized ionic liquid as a homogeneous and recyclable catalyst for the one-pot synthesis of $\alpha$-aminophosphonates. Tetrahedron Lett. 2009, 50, 4236.

151.Maghsoodlou, M. T.; Khorassani, S. M. H.; Hazeri, N.; Rostamizadeh, M.; Sajadikhah, S. S.; Shahkarami, Z.; Maleki, N. An efficient synthesis of $\alpha$-aminophosphonates using silica sulfuric acid as a heterogeneous catalyst. Heteroatom Chem. 2009, 20, 316.

152. Vahdat, S. M.; Baharfar, R.; Tajbakhsh, M.; Heydari, A.; Baghbanian, S. M.; Khaksar, S. Organocatalytic synthesis of $\alpha$-hydroxy and $\alpha$-aminophosphonates. Tetrahedron Lett. 2008, $49,6501$.

153. Karimi-Jaberi, Z.; Amiri, M. One-pot synthesis of $\alpha$-aminophosphonates catalyzed by boric acid at room temperature. Heteroatom Chem. 2010, 21, 96.

154.Babu, M. F. S.; Babu, B. H.; Reddy, K. R. K. K., Raju, C. N.; Reddy, C. S. Synthesis of substituted 8-(aminobenzyl)dioxaphosphocine 8-oxides. Chem. Heterocyclic Comp. 2007, 43, 1336.

155.Reddy, Y. T.; Reddy, P. N.; Kumar, B. S.; Sreenivasulu, N.; Rajitha, B.: $\mathrm{VCl}_{3}$ catalyzed efficient one-pot synthesis of $\alpha$-aminophosphonates. Heterocyclic Commun. 2005, 11, 153.

156.Reddy, Y. T.; Reddy, P. N.; Kumar, B. S.; Rajput, P.; Sreenivasalu, N.; Rajitha. B. TiCl $4^{-}$ catalyzed efficient one-pot synthesis of $\alpha$-aminophosphonates. Phosphorus, Sulfur \& Silicon 2007, 182, 161.

157.Paraskar, A. S.; Sudalai, A. A novel $\mathrm{Cu}(\mathrm{OTf})_{2}$ mediated three component high yield synthesis of $\alpha$-aminophosphonates. Arkivoc 2006, 183. 
158. Manjula, A.; Rao, V. One-pot synthesis of $\alpha$-aminophosphonates. Synth. Commun. 2003, 33, 2963.

159. Manabe, K.; Kobayashi, S. Facile synthesis of $\alpha$-aminophosphonates in water using a Lewis acid-surfactant-combined catalyst. Chem. Commun. 2000, 669.

160.Maghsoodlou, M. T.; Habibi-Khorassani, S. M.; Heydari, R.; Hazeri, N.; Sajadikhah, S. S.; Rostamizadeh, M. $\mathrm{Al}\left(\mathrm{H}_{2} \mathrm{PO}_{4}\right)_{3}$ as an efficient and reusable catalyst for one-pot threecomponent synthesis of $\alpha$-aminophosphonates under solvent-free conditions. Chin. J. Chem. 2010, 28, 285.

161.Chandrasekkar, S.; Narsihmulu, Ch.; Sultana, S. S.; Saritha, B.; Prakash, S. J. Solvent and catalyst free three-component coupling of carbonyl compounds, amines and triethyl phosphite; a new synthesis of $\alpha$-aminophosphonates. Synlett 2003, 505.

162.Edman, P. On The mechanism of the phenyl isothiocyanate degradation of peptides. Acta Chemica Scand. 1956, 10, 761.

163. Molnar-Perl, I. HPLC of amino acids as phenylthiocarbamoyl derivatives. In Book: Quantitation of amino acids and amines by chromatography. Methods and protocols. Molnar-Perl, I. Ed.; Elsevier: Journal of Chromatography Library 2005, 70, 137. 